Portland State University

PDXScholar

\title{
Geophysical and geological analysis of a fault-like linearity in the lower Clackamas River area, Clackamas County, Oregon
}

Ronald Jay Schmela

Portland State University

Follow this and additional works at: https://pdxscholar.library.pdx.edu/open_access_etds

Part of the Geology Commons, Geophysics and Seismology Commons, and the Tectonics and Structure Commons

Let us know how access to this document benefits you.

\section{Recommended Citation}

Schmela, Ronald Jay, "Geophysical and geological analysis of a fault-like linearity in the lower Clackamas River area, Clackamas County, Oregon" (1971). Dissertations and Theses. Paper 1426.

https://doi.org/10.15760/etd.1425

This Thesis is brought to you for free and open access. It has been accepted for inclusion in Dissertations and Theses by an authorized administrator of PDXScholar. Please contact us if we can make this document more accessible: pdxscholar@pdx.edu. 
AN ABSTRACT OF THE THESIS OF Ronald Jay Schmela for the Master of Science in Earth Science presented September 10, 1971.

Title: Geophysical and Geological Analysis of a Fault-like

Linearity in the Lower Clackamas River Area,

Clackamas County, Oregon.

APPROVED BY MEMBERS OF THE THESIS COMMITTEE:

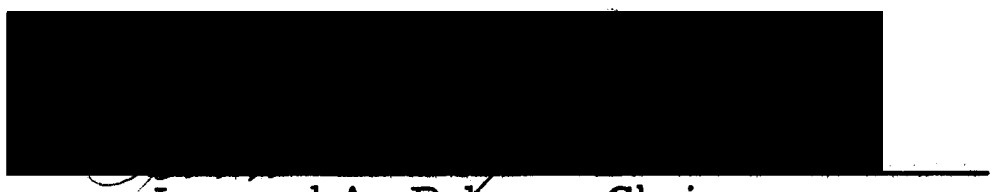

Leonard A. Palmer, Chairman

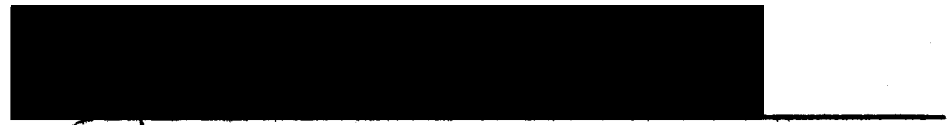

Sdhn E. Allen

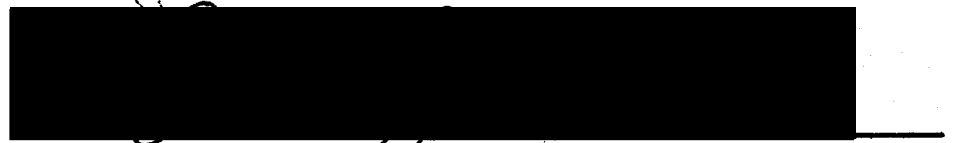

Dan J. Cash

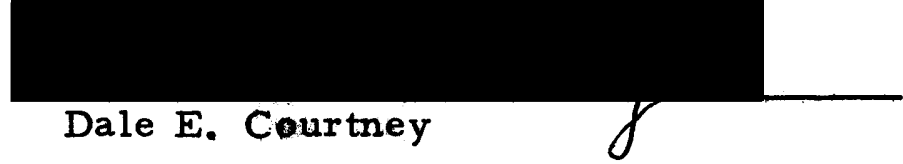

A fault-like linearity along the lower Clackamas River is evaluated by analysis of physiographic and structural alignments, geological relationships, and by gravity and magnetic data. The study has resulted in the verification of a structural feature extending along the Clackamas River and the eastern front of the Portland Hilla. 
Physiographic alignments were examined in twelve 15 minute and two 7-1/2 minute quadrangle maps. A significant northeasterly morphologic trend, N. $20^{\circ} \mathrm{W}$. and N. $40^{\circ} \mathrm{W}$. , and other secondary trends, namely, the N-S, E-W, and N. 50-60 E., has developed in the Portland area. The consistent northwest trend is observed throughout the entire area studied which strongly suggests that the alignments are very good indicators of underlying structural features. Structural alignments show that approximately $60 \%$ of the known mapped faults and fold axes concur with the dominant northwest physiographic trend. Seismic first motion analysis supports the established morphologic trend.

A series of regionally co-aligned morphologic and structural features striking S. $40-50^{\circ}$ E. across the state of Oregon suggest the presence of a major structural fault system aligned with the Portland Hills-Clackamas River structural alignment.

The geologic cross sections developed from map and well data generally lack any tangible evidence as to the nature of the physiographic alignment. An apparent offset of the lower Pliocene Sandy River mudstone suggests movement as recent as middle Pliocene.

Geophysical information was obtained from six gravity traverses and three magnetic traverses. The consistency of the size and shape of the gravity anomaly, 2.18 milligals $/ 0.2$ mile, downdropped to the east, across the physiographic alignment 
defines the zone of a fault or a steep fold developed in the Columbia River basalt. The magnetic anomalies show a consistent change in the magnetic gradient corresponding to the structural zone. 


\section{VITA}

The writer, Ronald Jay Schmela, was born in Pasadena, California on April 15, 1945. He graduated from Ventura High School, Ventura, California in June, 1963. He received his Bachelor of Science degree from the University of Redlands, Redlands, California in June, 1967. In 1969, he enlisted in the Oregon National Guard while attending the University of Oregon as a graduate student. Afterward he transferred to Portland State University in September, 1969 and has since been a graduate student. 
GEOPHYSICAL AND GEOLOGICAL ANALYSIS OF A FAULT-LIKE LINEARITY IN THE LOWER CLACKAMAS RIVER AREA, CLACKAMAS COUNTY, OREGON

by

RONALD JAY SCHMELA

A thesis submitted in partial fulfillment of the requirements for the degree of

\title{
MASTER OF SCIENCE \\ in \\ EAR TH SCIENCE
}

\author{
Portland State University
}

1971 
TO THE OFFICE OF GRADUATE STUDIES:

The members of the Committee approve the thesis of Ronald Jay Schmela presented September 10, 1971.

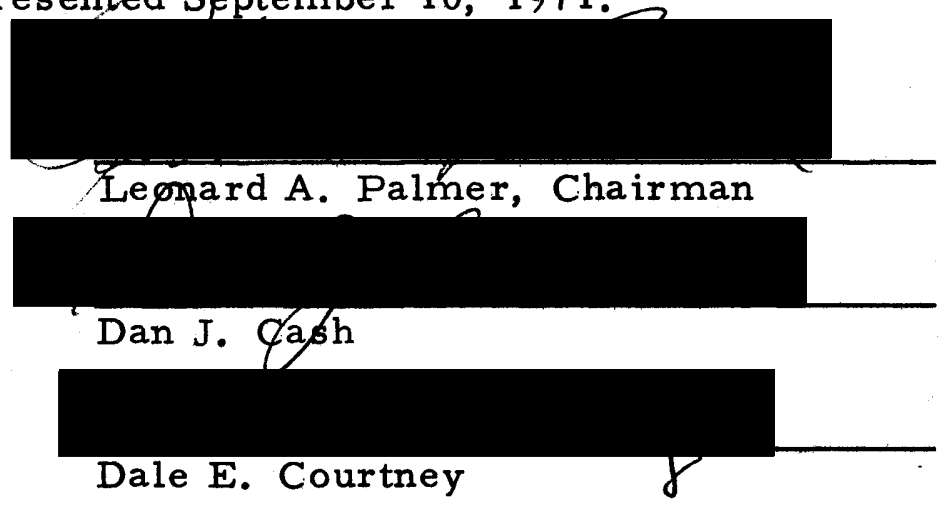

APPROVED:

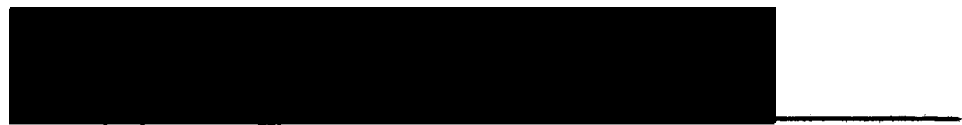

Johit E. Allen, Head, Earth Scignce

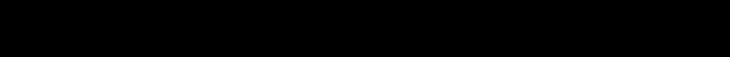

David T. Clark, Dean of Graduate Studies 


\section{ACKNOW LEDGEMENTS}

The writer wishes to express his gratitude to Dr. L. A. Palmer, the thesis adviser, for his suggestions and guiding assistance in discussing problems and correcting the manuscript.

The writer also wishes to thank Dr. R. Blank, University of Oregon, for his unselfish donation of time in discussing the data. Thanks are also due to Dr. R. Couch and Dr. D. F. Heinrichs, Oregon State University, for their assistance in the project.

Special thanks are due to Dr. R. Blank, University of Oregon, for loan of the fluxgate magnetometer, and Dr. R. Couch, Oregon State University, for loan of the Worden gravity meter for without these instruments this thesis would not have been possible.

Thanks are due to Mr. Tomaž Rupnik for his contributions in writing the computer program for the theoretical gravity. The writer also wishes to thank Mr. R. E. Corcoran, Oregon Department of Geology and Mineral Industries, for his support of the thesis and assistance in obtaining use of a state car.

Appreciation is expressed to Dr. J. E. Allen, Dr. M. H. Beeson, and Dr. D. J. Cash for their criticism of the manuscript. 
Thanks are also due to the geology department for use of their field and laboratory equipment and the duplicating department. The writer wishes to thank his wife, Carol, for her help in the fieldwork and for her enduring patience and inspiration. 
TABLE OF CONTENTS

\section{PAGE}

ACKNOW LEDGEMENTS . . . . . . . . . . . • iv LIST OF TABLES . . . . . . . . . . . . • ix LIST OF FIGURES . . . . . . . . . . . . . • x

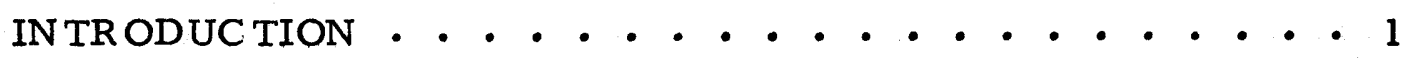

Purpose and Scope . . . . . . . . . . . . . 1 Location and Planimetric Base Control . . . . . . 2 Previous Work . . . . . . . . . . . . . 5 Fieldwork .................. . 8 PHYSIOGRAPHIC AND STRUCTURAL ALIGNMENTS $\cdot \cdot \cdot 13$ GEOLOGICAL INVESTIGA TIONS . . . . . . . . 23 GEOPHYSICAL METHODS $\cdot$. . . . . . . • . 24

Gravimetric . . . . . . . . . . . 24

Magnetic . . . . . . . . . . . . 25 INTER PRETATIONS . . . . . . . . . . . 26

Physiographic and Structural Alignments . . . - 26 Geologic Thickness Relationships and Gravity Profiles • 29

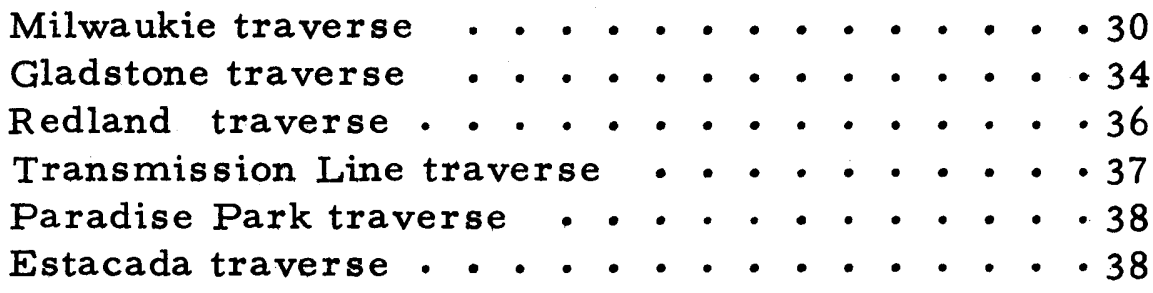

Significance of the Geologic Cross Sections and the Bouguer Anomalies . . . . . . . . 39 
PAGE

Magnetic Profiles . . . . . . . . . . . 40

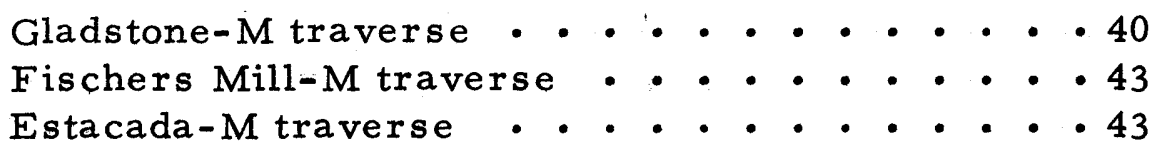

Significance of the Magnetic Anomalies . . . . . • 44 CONCLUSIONS AND RECOMMENDATIONS • • • • • • • 45

Recommendations . . . . . . . . . . . 46 REFERENCES CITED - • • • • • • • • • • • • • 48 APPENDIX I DESCRIPTION OF BENCH MARKS • • • • • 55 APPENDIX II GEOLOGY • • • • • • • • • • • • 57

Geologic Setting • • • • • • • 57 Stratigraphy - • • • • • • • 58

Tertiary System • . . . . 59

Skamania Volcanic Series - 59 Scappoose Formation. - 59

Columbia River Basalt • . 61 Rhododendron Formation . .62 Sandy River Mudstone •. 63 Troutdale Formation . . 64

Tertiary and Quaternary Systems $\cdot 65$

Boring Lava . . . . 65

Quaternary System •. •. • 65

Springwater Formation • . 65 Gresham Formation . •. 66 Estacada Formation . . . 66 Alluvium of Abandoned

River Channel . . . 66

Recent Alluvium • • • • 67 
PAGE

APPENDIX III GRAVITY REDUCTIONS . . . . . . . . 69

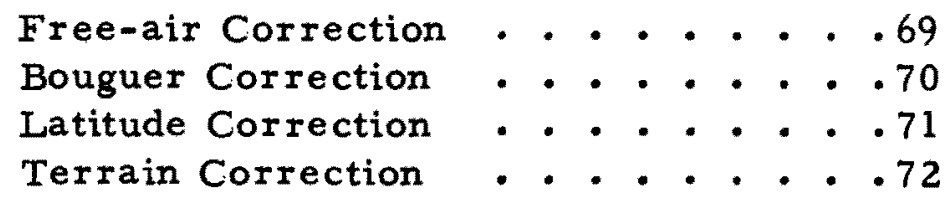

The Hammer method . . . . .73

Drift Correction . . . . . . . 76

Accuracy of Reductions . . . . . . 78

Instrument reading ... . . . 78

Free-air correction . . . . . 78

Bouguer correction ... . . . 80

Latitude correction . . . . . 80

Terrain correction ... . . 81

Drift correction. . . . . . .81

Probable maximum error . . . 82

The Bouguer Anomaly . . . . . 82

APPENDIX IV GRAVITY CORRECTION TABLES $\cdot . . \cdot .84$

Key to Correction Tables ...... 84

Milwaukie Traverse . . . . . 85

Gladstone Traverse . . . . . 85

Redland Traverse . . . . . . 86

Transmission Line Traverse. . .87

Paradise Park Traverse . . . 88

Estacada Traverse . . . . . 89

APPENDIX V MAGNETIC DATA . . . . . . . 90

Gladstone-M Traverse . . . . . .90

Fischers Mill-M Traverse. . . . . 90

Estacada-M Traverse ....... . 91

APPENDIX VI WELL LOGS . . . . . . . . . . . 92

Drillers'Logs of Representative Wells, . 94 


\section{LIST OF TABLES}

TABLE

PAGE

1 Terrain-correction Table . . . . . . . . . 75 


\section{LIST OF FIGURES}

FIGURES

PAGE

1 Location map . . . . . . . . . . . . . 3

2 Location of gravity traverses, gravity stations, and water wells . . . . . . . . . . . . . 4

3 Location of magnetic traverses and magnetic stations . . . . . . . . . . . . 6

4 Location of gravity base stations in Portland,

Oregon ... . . . . . . . . . . . . . 11

5 Demarcation of physiographic alignments . . . . . 14

6 Orientation-length distribution of physiographic alignments . . . . . . . . . . . . . 16

7 Orientation-length distribution of faults in the Portland area . . . . . . . . . . . . 18

8 Geologic map of Oregon . . . . . . . . . . 20

9 Summary of all orientation-length distribution of physiographic alignments . . . . . . . . . 27

10 Complete Bouguer gravity anomaly map of northwestern Oregon . . . . . . . . . . 31

11 Graphic representation of various gravity anomalies and corresponding geometric forms . . . . . . 33

12 Graphic representation of one interpretation of the Bouguer gravity anomaly . . . . . . . . 35

13 Composite Bouguer anomaly corresponding to the structural zone . . ... . . . . . . . . . 41 
14 Graphic representation of various magnetic anomalies and corresponding geometric forms . . . . . . . .42

15 Geologic map of thesis area ............ 60

16 Terrain correction zone chart. . . . . . . . . . 74

17 Schematic outline of closed loop traverse method . . . 77

18 Drift curve . . . . . . . . . . . . . 79

19 Milwaukie traverse . . . . . . . . . In pocket

20 Gladstone traverse . . . . . . . . . In pocket

21 Redland traverse . . . . . . . . . . . In pocket

22 Transmission Line traverse $\cdot \cdot^{-} \cdot \cdot^{-} \cdot \cdot^{-} \cdot$ In pocket

23 Paradise Park traverse . . . . . . . . In pocket

24 Estacada traverse . . . . . . . . . In pocket

25 Fischers Mill traverse . . . . . . . . In pocket

26 Explanation of well numbering system . . . . . . . 93 


\section{INTR ODUCTION}

\section{Purpose and Scope}

A fault-like linearity along the lower Clackamas River is evaluated by analysis of physiographic and structural alignments, geological relationships and by gravity and magnetic data. The objective of this investigation is to provide data which may verify the existence of a structural feature extending along the Clackamas River and the eastern front of the Portland Hills. Lava flows, alluvium and vegetation obscure the nature of the linearity thus requiring the use of indirect physiographic and geophysical methods.

To obtain the necessary data, twelve 15 minute and two 7-1/2 minute quadrangle maps were examined for physiographic alignments. Geophysical information was obtained from 6 gravity traverses, averaging 2 miles in length. The 166 gravity stations and 50 magnetic stations are plotted as cross profiles, correlated to surface geology. Geologic information was obtained from previous studies, especially from a report by Trimble (1963) and from analysis of well logs. 


\section{Location and Planimetric Base Control}

The physiographic investigation included about 2623 square miles in northwestern Oregon and southwestern Washington as shown in figure 1. Physiographic alignments were plotted from twelve of sixteen 15 minute quadrangles bounded by $122^{\circ} 00^{\prime}$ and $123^{\circ} 00^{\prime}$ west longitude and $45^{\circ} 00^{\prime}$ and $46^{\circ} 00^{\prime}$ north latitude and two 7-1/2 minute quadrangles bounded by $122^{\circ} 45^{\prime}$ and $123^{\circ} 00^{\prime}$ west longitude and $46^{\circ} 00^{\prime}$ and $46^{\circ} 7.5^{\prime}$ north latitude.

The geophysical studies were conducted in a rectangular area, approximately 75 square miles, bounded between the following geographic points also shown on figure 1.

West Longitude

(1) $122^{\circ} 41^{\prime}$

(2) $122^{\circ} 38^{\prime}$

(3) $122^{\circ} 17^{\prime}$

(4) $122^{\circ} 20^{\prime}$
North Latitude

$45^{\circ} 24^{\prime}$

$45^{\circ} 28^{\prime}$

$45^{\circ} 18^{\prime}$

$45^{\circ} 14^{\prime}$

The six gravity traverses have been given locational names. Their location and the approximate location of each gravity station is indicated in figure 2. Starting from the northwest end of the investigated geophysical area the traverse names are: (1) Milwaukie,
(2) Gladstone,
(3) Redland,
(4) Transmission Line,
(5) Paradise

Park, and (6) Estacada Traverse. All gravity stations were located by reference to U. S. Geological Survey 7-1/2 minute quadrangle 


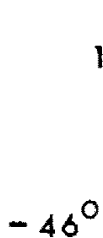

$123^{\circ}$

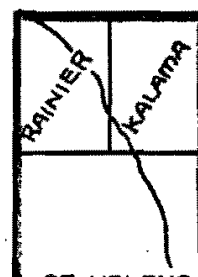

ST HELENS

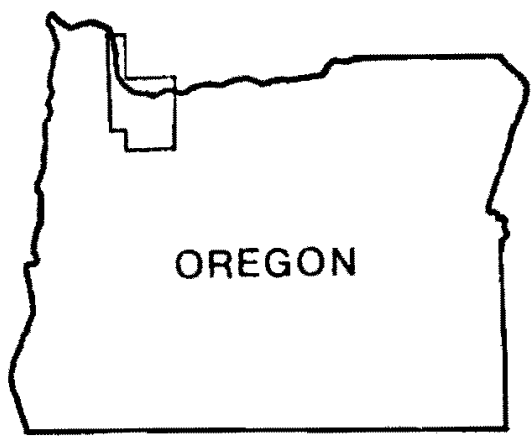

SCALE

$11,000,000$

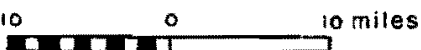

miles

$122^{\circ}$

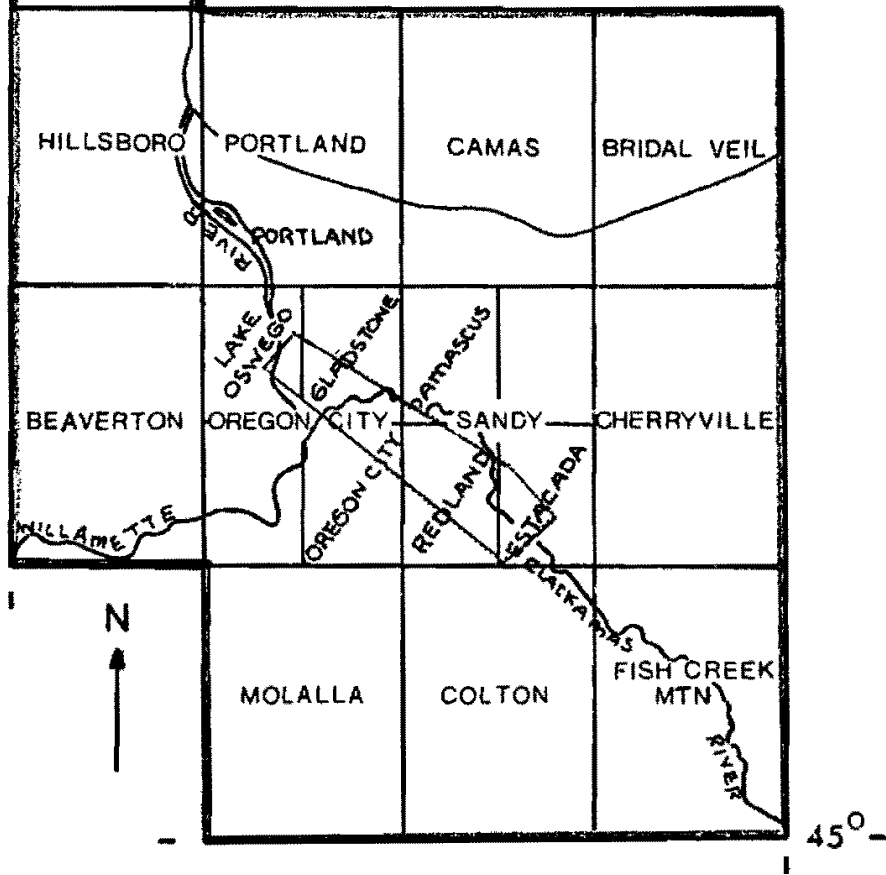

Boundary of physiographic alignment study

Bcundary of geophysically investigated area

Figure 1. Location map. 


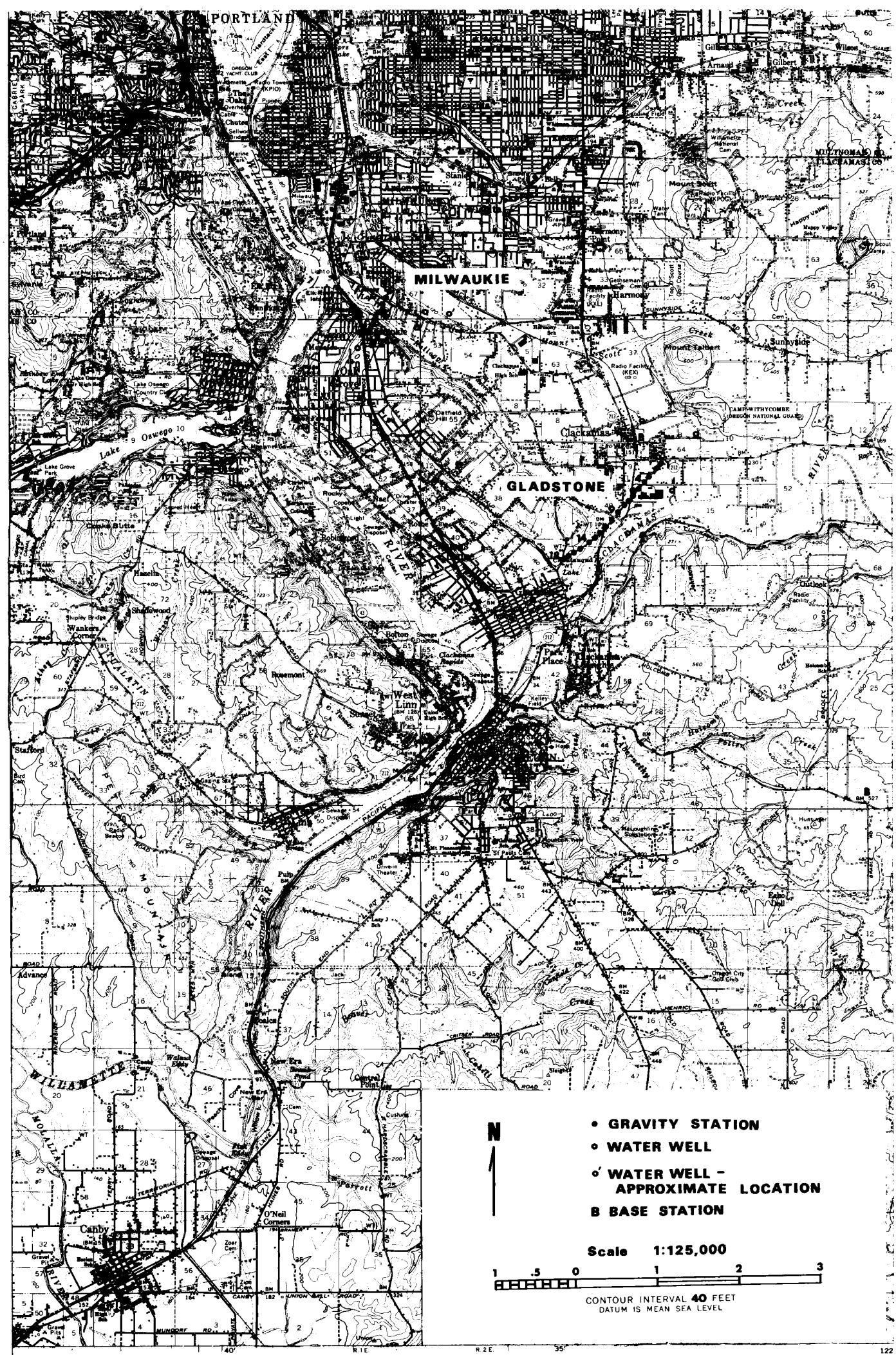

Figure 2. Location of gravity traverses, gravity stations, and water wells. 
maps, namely, Lake Oswego, Gladstone, Damascus, Oregon City, Redlands, and Estacada.

All base stations were located from existing bench marks established by (1) U. S. Geological Survey, (2) U. S. Coast and Geodetic Survey, or (3) City of Portland. A full description of these bench marks is listed in Appendix I.

Elevation and terrain corrections were estimated in parts or all of the Hillsboro, Portland, Camas, Bridal Veil, Beaverton, Oregon City, Sandy, Cherryville, Molalla, Colton, and Fish Creek 15 minute quadrangle sheets.

The three magnetic traverses have been given locational names. Their location and the approximate location of each magnetic station is indicated in figure 3. From the northwest end of the geophysically investigated area the traverse names are: (1) Gladstone-M ( $\mathrm{M}$ stands for magnetic), (2) Fischers Mill-M, and (3) Estacada-M Traverse.

\section{Previous Work}

Several geologic reconnaissance investigations have been conducted in the general area under study. Diller, who was first to believe a fault fronted the Tualatin Mountains (Portland Hills), studied the area in 1896 and later in 1915. Darton (1909), Washburne (1914), Williams (1916), Treasher (1924b), Gilchrist (1952), Elsey (1955) and others have made limited geologic studies in the area. 


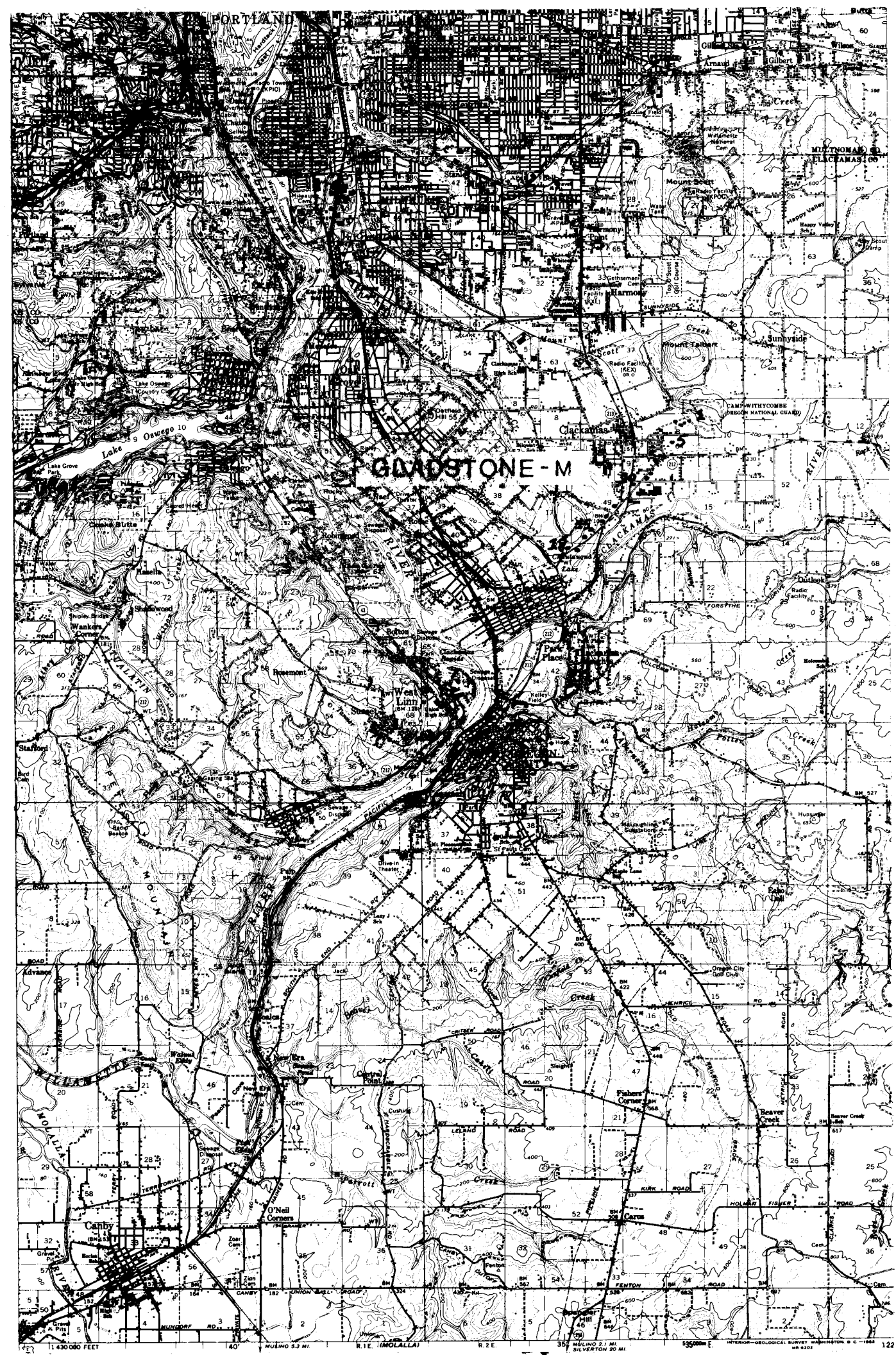

Figure 3. Location of magnetic traverses and magnetic stations. 
Recent geologic studies since about 1955 have been more detailed than their predecessors. The first comprehensive study was conducted by Trimble (1957 and 1963). Peck and others (1964) studied the northern part of the Western Cascade Range in Oregon and Snavely and Wagner (1964) conducted a geologic sketch of northwestern Oregon. Wells and Peck (1961) published a Geologic Map of Oregon West of the 121 st Meridian. The Troutdale formation was first described by Hodge (1938). Treasher (1942b) published a reconnaissance map covering the Portland, Camas, Oregon City, and Sandy quadrangles.

Brief historical accounts which include the Portland area are contained within publications by Hodge (1933), Treasher (1942a), Stauffer (1956), Baldwin (1957 and 1964), Snavely and Wagner (1963), Trimble (1963), Mackin and Cary (1965), and Hogenson and Foxworthy (1965). The effects of the Spokane (Missoula) Flood have been reviewed by Bretz (1925, 1928, 1956, and 1959) and Allison (1932, 1933 , and 1935).

Earthquake studies in the region include those made of the November 5, 1962 earthquake by Dehlinger and Berg (1962), Westphal (1962), and Dehlinger and others (1963). The January 27, 1968 and May 13, 1968 Portland earthquakes have been studied by Heinrichs and Pietrafesa (1968) and Couch and others (1968), respectively. Schlicker and others (1964) studied the earthquake geology of the 
Portland area; Berg and Baker (1963) reviewed Oregon earthquakes from 1841 to 1958 and Couch and Lowell (1971) studied the earthquakes and seismic energy release in Oregon.

Gravity studies in the area include absolute gravity stations established in Oregon at the Portland International Airport and at the Portland Custom House by Wollard (1958). Woollard and Rose (1963) published a regional Bouguer gravity map for the state of Oregon. More recent regional gravity studies in Oregon have been conducted by Berg and Thiruvathukal (1965, 1967a, 1967b, and 1967c), Thiruvathukal and Berg (1966), Thiruvathukal, Berg, and Henricks (1970). Bromery and Snavely (1964) and Blank (1966) discuss geophysical surveys in western Oregon.

General references on geophysical techniques as used in this study are discussed in texts such as Nettleton (1940), Heiskanen and Meinesz (1958), Gutenberg (1959), Dobrin (1960), and Heiland (1968). Density determination for gravimeter observations is given by Nettleton (1939). Hammer (1939) and Sandberg (1958) discuss terrain correction techniques. Interpretation of anomalies is discussed by Nettleton (1940, 1942, and 1954), Dobrin (1960, and Skeels (1963)..

\section{Fieldwork}

Fieldwork was done during winter and spring of 1971 with some preliminary work fall, 1970. The fieldwork involved establishing 
lateral and vertical control and making instrument readings.

Lateral and vertical control was established by use of an automobile odometer and by reference to physiographic and topographic features on the 7-1/2 minute quadrangle maps. Use of a Paulin microaltimeter was not practical due to diurnal barometric fluctuations. To assure the detail of the local gravity and magnetic anomalies a station spacing with one tenth mile interval was established. The gravity and magnetic stations were located for convenient access. The routes of the traverses are located upon established roads in the area. The Transmission Line traverse, however, was conducted entirely off surface roads. Topographic description of this line, the John Day-Keeler No. 1, was supplied by Portland General Electric. The description greatly facilitated the correct location of each station along the line.

The instrument readings for gravity were made from a Worden 1 gravity meter - Master Model (Meter No. 575) loaned by the Department of Oceanography at Oregon State University. The instrument has a sensitivity of .1037 milligals per division (ABSOLUTE). The meter is self-compensating for normal ambient temperature changes but can be operated with or without thermostating. For the purpose of this study, the sensitivity of the instrument is excellent. The 
instrument is able to detect gravity differences as low as 0.01 milligals.

Closed loop traverses were made on all observed readings to correct for instrument drift, earth tides, and other factors that might influence the observed reading. Gravimetric field observations were planned with assistance and advice from Dr. Richard Couch, Oregon State University. The method is described in more detail under drift corrections.

Two existing absolute gravity stations were occupied so that the study could be tied to a national gravity network. This allows correction of values to terms of absolute gravity. The absolute gravity stations that were established by Woollard (1958) are located at Portland International Airport and at the Portland Custom House (figure 4). The corrected values are 980648.24 and 980647.23 milligals, respectively (Woollard, 1958).

A Model MF-1 ${ }^{2}$ fluxgate magnetometer loaned by the Center of Volcanology of the University of Oregon was used to obtain the magnetic data. The instrument has a maximum total range of $\pm 100,000$ gammas. The meter is a vertical component magnetometer which is self-compensated for temperature variations and requires no directional orientation. The instrument reads directly in gammas. The

${ }^{2}$ GISCO - Geophysical Instrument and Supply Company 


\section{PORTLAND INTERNATIONAL AIRPORT}

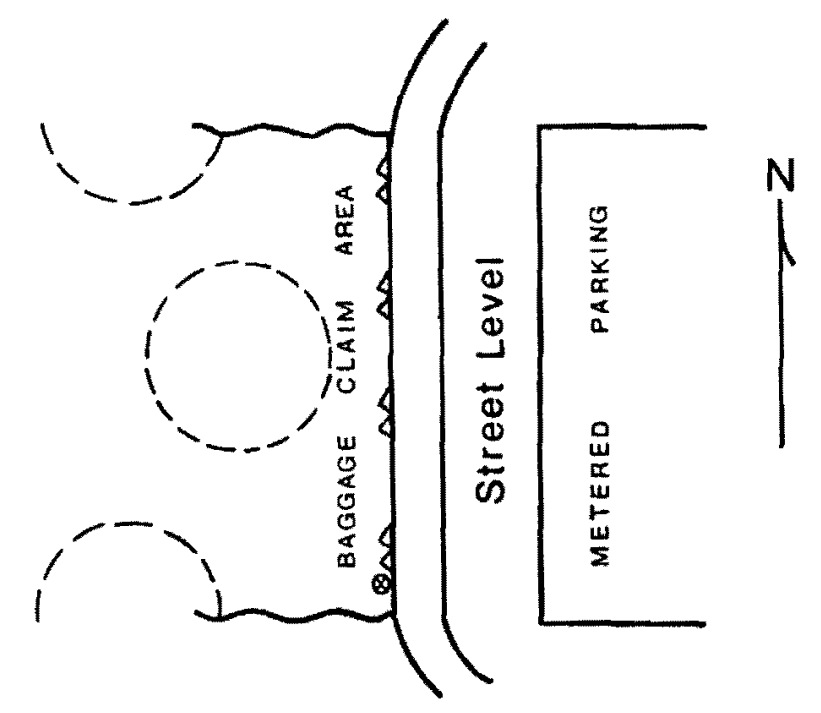

980648.24

\section{PORTAND CUSTOM HOUSE}

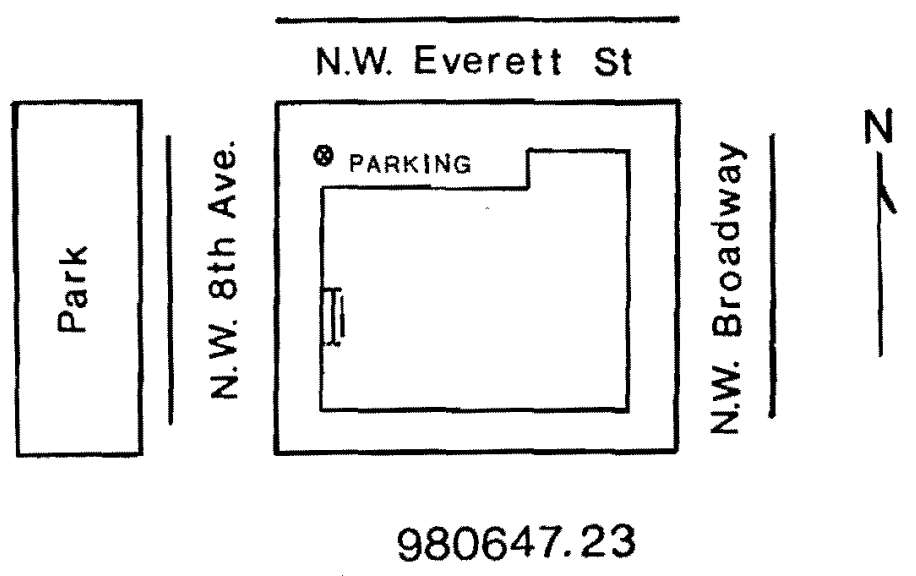

Figure 4. Location of gravity base stations in Portland, Oregon (after Rinehart and others, 1964; gravity values after Berg and Thiruvathukal, 1965). 
operation of the magnetometer was conducted under guidance of Dr. Richard Blank, University of Oregon.

In order to correct for diurnal variations and other factors influencing the observed readings, the magnetic stations were occupied using the closed loop traverse method described for the gravity meter.

All data for both the gravity meter and the magnetometer are presented in Appendix IV and V. All elevations are in feet above mean sea level. All gravity and magnetic readings have been corrected for drift and diurnal variations. 


\section{PHYSIOGRAPHIC AND STR UCTURAL ALIGNMENTS}

Morphological analysis of linear landforms represented on topographic maps was performed to evaluate alignments for structural significance. Twelve 15 minute and two 7-1/2 minute U. S. Geological Survey topographic quadrangle maps were studied and analyzed for quantitative distribution of length and orientation of alignments. Geologic maps were similarly evaluated for orientation of faults and fold axes and compared to the morphologically determined orientations.

Linear landforms may be significant indicators of the underlying geological structures. Differential erosion commonly reflects alignments such as faults, joints, or bedding (Ray, 1960; von Bandat, $1962)$.

The method used in analyzing linear landforms is not complicated and is not subject to significant interpreter bias. The procedure used in this study is illustrated in figure 5 and is as follows:

(1) Preliminary marking of all linear landforms on the topographic map longer than an arbitrary minimum preselected length of about $1 / 2$ inch. The linear features include stream courses, ridge crests, and linear breaks in slope angle. 


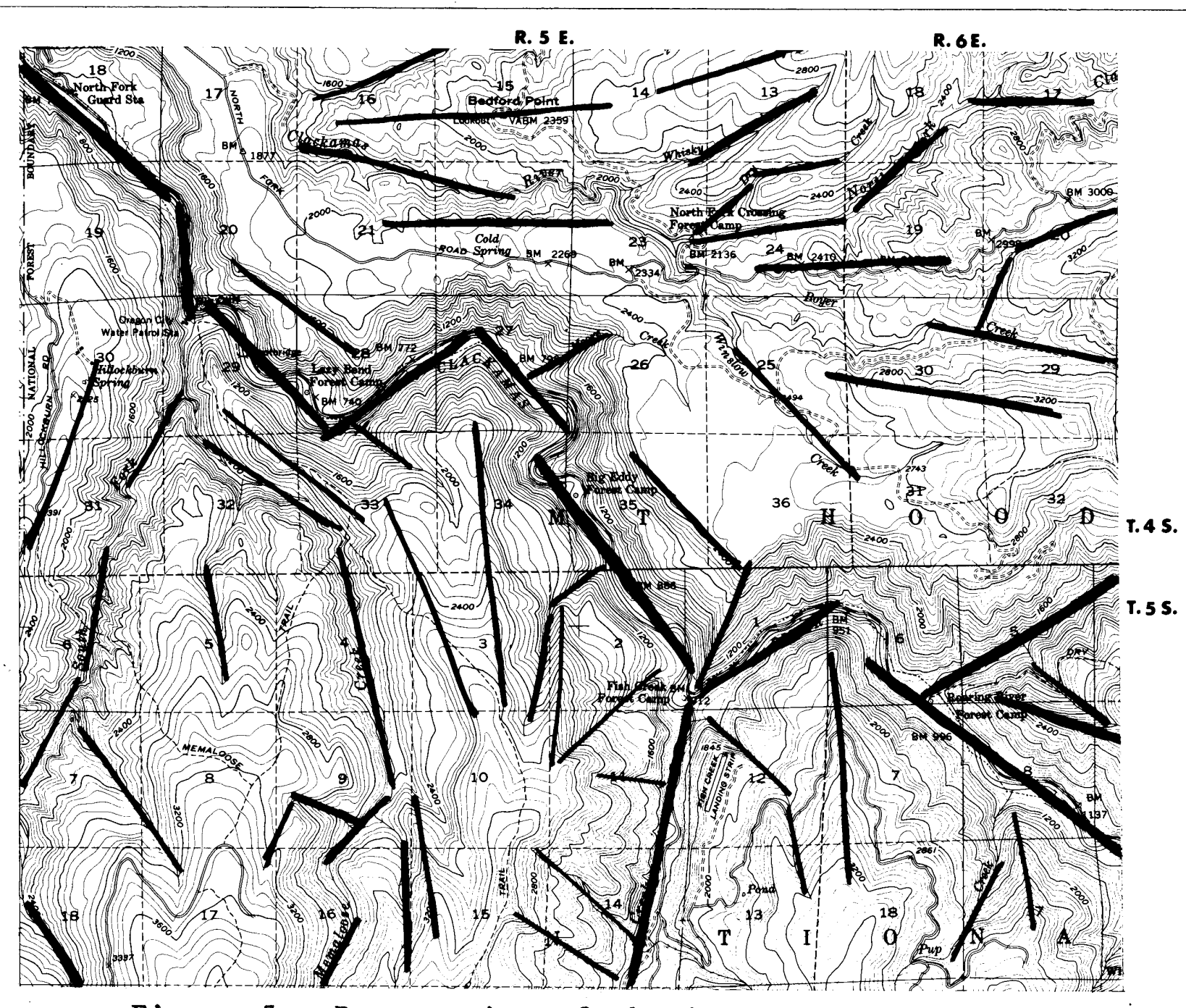

Figure 5. Demarcation of physiographic alignments. Portion of Fish Creek Mountain 15' quadrangle map. 
(2) Measurements of length and orientation of each linear feature are tabulated in 10 degree orientation subdivisions for each quadrangle map.

(3) Calculation of percentage fraction of lineation lengths for each 10 degree subdivision for each map.

(4) Graphical plotting of alignment statistics in rose-type diagrams for each map.

(5) Summation of alignments for all maps into a composite rose diagram.

(6) Comparison with mapped faults and folds is done using steps 2 through 5 on published fault lines.

This procedure was followed for each of the 14 topographic maps and is tabulated in figure 6.

Anomalies from random orientation are believed to reflect the regional structural alignment of the area. In analyzing the fourteen quadrangles (figure 6, summary diagram) a strong regional preferred orientation is shown to be N. $20^{\circ}$ and $40^{\circ} \mathrm{W}$. There also exists a less prominent $\mathrm{N}-\mathrm{S}$ and N. $50^{\circ}$ E. preferred orientation. The prominence of the northwest trend over all other directions suggests significant underlying structural orientations.

Further confirmation of the structural significance of the northwesterly morphological trend is shown by the similarity to orientation of known fault trends, regional trends of fold axes, and trends 


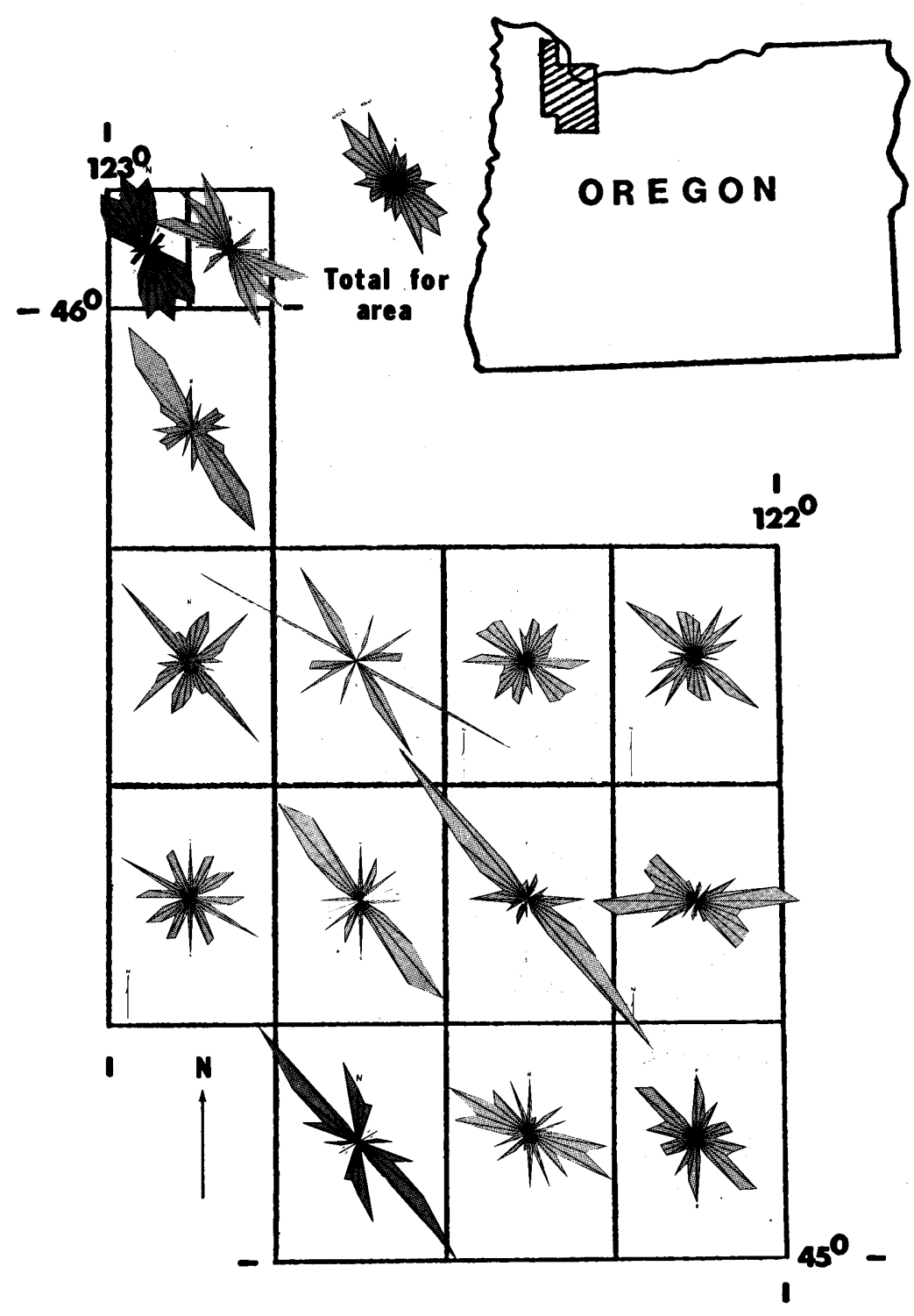

Figure 6. Orientation-length distribution of physiographic alignments measured in individual quadrangle sheets. Summary diagram represented by "total for area." Quadrangle names are listed on the location map, figure 1. 
determined by seismic first motion analyses in the area. Faults that have been mapped in the Portland area show a very strong preferred orientation of N. $40^{\circ} \mathrm{W}$. (figure 7). Secondary preferred orientations of $\mathrm{N}-\mathrm{S}$ and N. $50^{\circ} \mathrm{E}$. occur.

The regional trends of fold axes also reflect the dominant northwest trend. The structural folds generally prefer an orientation of N. $40-45^{\circ} \mathrm{W}$.

Seismic first motion analysis of the November 5, 1962 Portland earthquake suggests a motion source of a northwest-trending, rightlateral strike-slip fault. The source motion data, however, fits a northeast-trending, left-lateral strike-slip fault equally as well (Dehlinger and others, 1963). Westphal (1962) suggested that the seismic activity was related to the Portland Hills fault. Gallagher (1969) indicates that the motion from the November 5 earthquake occurred along a normal fault striking N. $54^{\circ} \mathrm{E}$. or along a rightlateral strike-slip fault striking N. $12^{\circ} \mathrm{W}$. The motion analysis was reported most consistent with the N. $54^{\circ}$ E. trending fault. This generally agrees with the secondary morphological and structural trend. The N. $12^{\circ} \mathrm{W}$. trend, however, falls somewhat to the north of the major morphological and geologic trend in the area.

In general, the various Portland-area geologic alignment trends are consistently sympathetic and parallel to the Portland Hills fault and the Clackamas River alignment. 


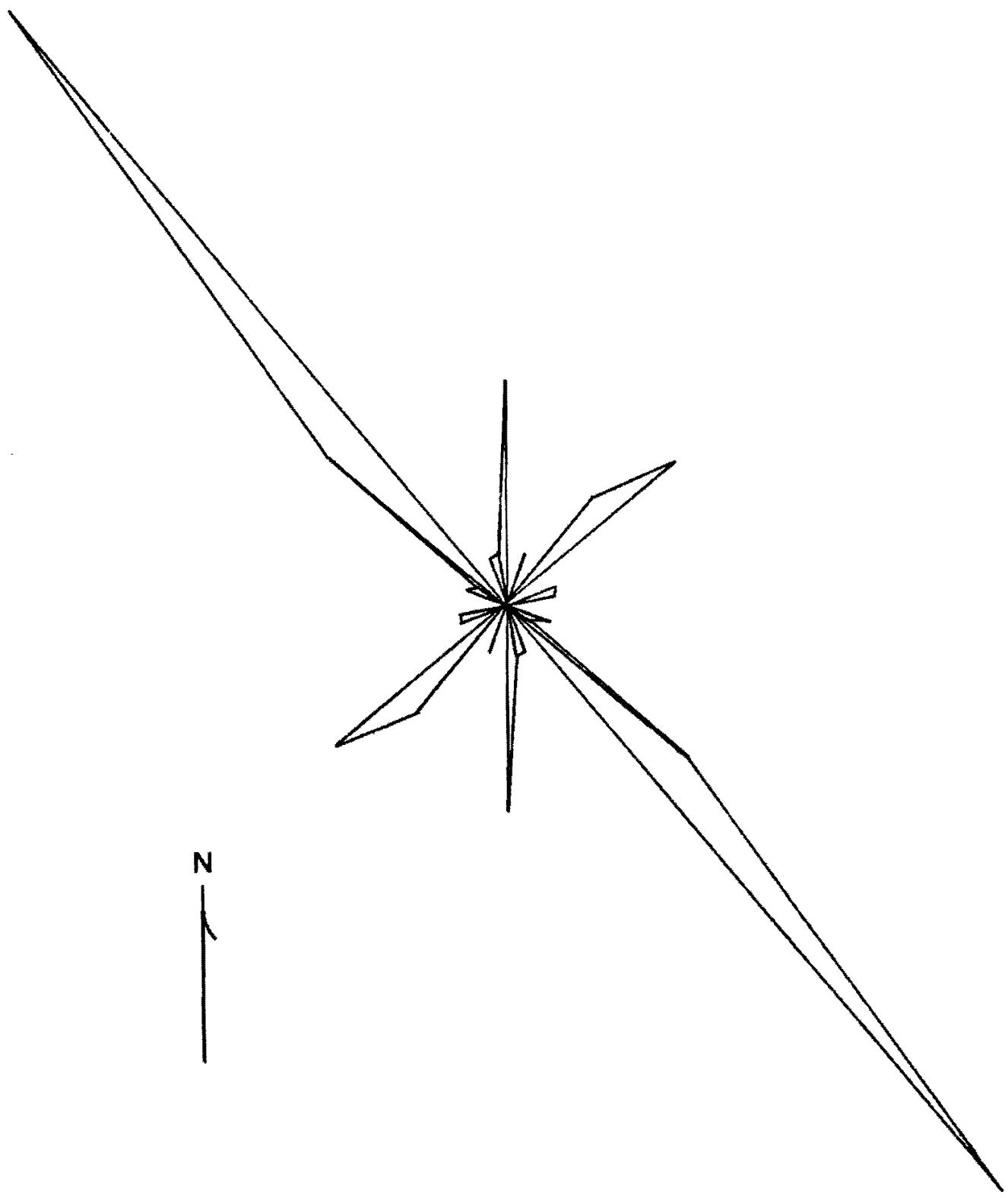

Figure 7. Orientation-length distribution of mapped faults in the portland area (using data from Schlicker and Deacon, 1967). 
Further confirmation of the significance of the northwesterly morphological trend is shown by a series of co-aligned linear morphologic features extending over 300 miles southeasterly across the state of Oregon. The regional features co-align with the Portland trend and include segments of the Metolius River, Crooked River, and the southern edge of Hampton Buttes. These prominent linear features align themselves in a general N. 40-50 $\mathrm{W} . \mathrm{S}, 40-50^{\circ} \mathrm{E}$. trend across the state of Oregon. The alignment is readily seen on the state $1: 250,000$ relief map, vertical exaggeration $2: 1$.

The geologic map of Oregon (Walker and King, 1969) shows numerous faults with a general regional trend of N. $40-50^{\circ} \mathrm{W}$. occuring along the above mentioned trend.(figure 8). The Brothers fault zone is one segment of the co-linear features (Higgins and Waters, 1967). It is believed that the normal faults associated with the Brothers fault zone and the small monoclinal folds to the faults are a surface reflection of a deeply buried fault with lateral displacement (Walker, 1969). Furthermore, several volcanic vents are concentrated along this segment of the state wide alignment. These vents are generally of Pliocene and Pleistocene age, however, some may be as late as Miocene and early Holocene age which indicates the span of time associated with this area of crustal disturbance (Walker, 1969).

The significance of the dominant trend in the Portland area 


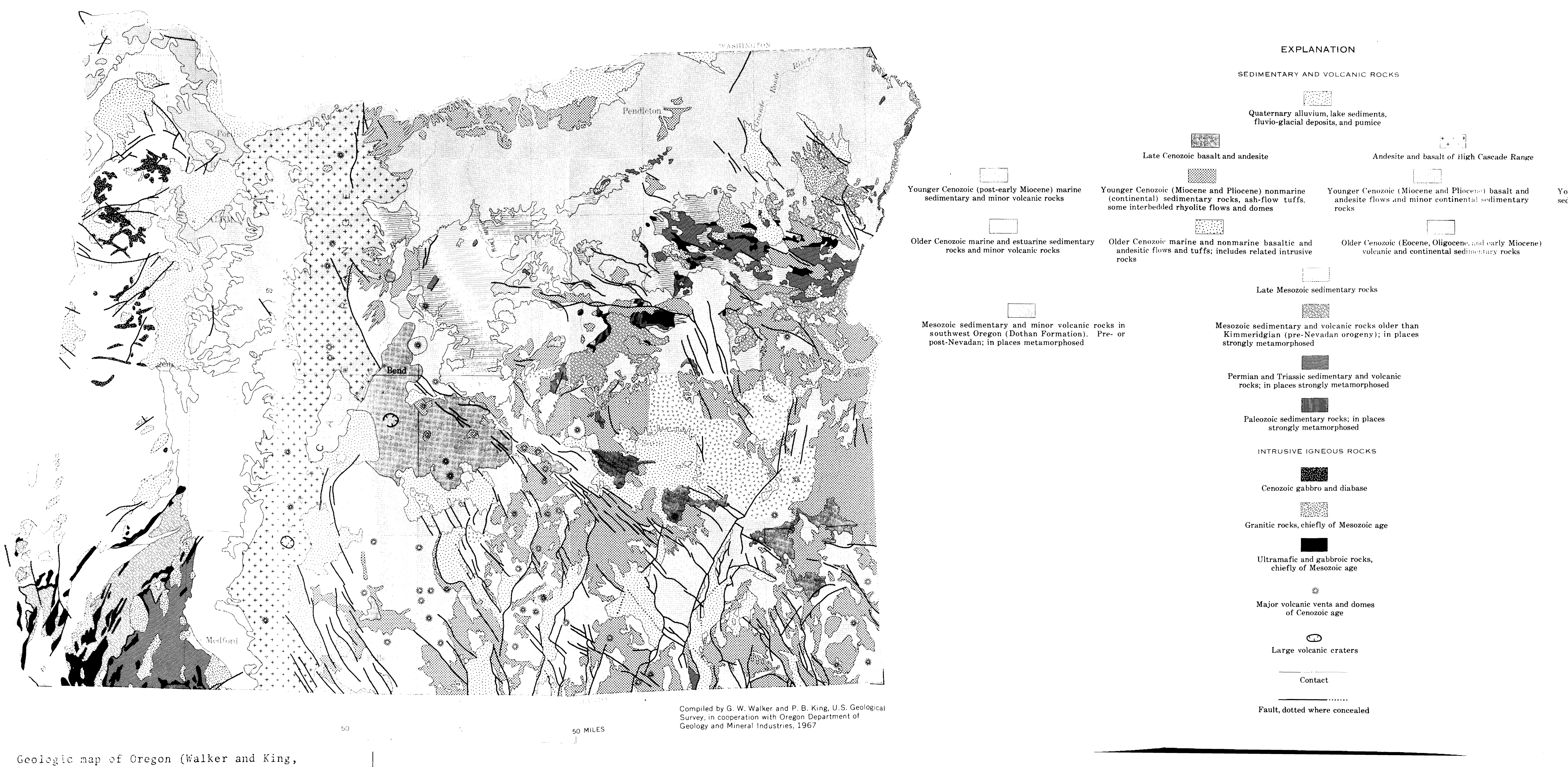


appears to be supported by the physiographic and structural alignments, and by seismic first motion analysis. The indication of a major regional aligned fault is shown by co-aligned topographic features which are parallel to the mapped faults in the area. Therefore, it is believed that this strikingly linear feature may be indicative of a structural feature of major importance.

The time of origin and mechanism of the structural alignment is not well known. Mackin and Cary (1965) have shown major trend development along a northwest-southeast alignment resulting from the folding of the Eocene Weaver Plain. They indicate that the recent alignments are trends developed from the ancestral Calkins Range, named by Mackin and Cary (1965), a range dominant during Oligocene time in the Pacific Northwest region. Mackin and Cary believe that the Calkins Range represents "the last of a long series of crustal yieldings along this fundamental pre-Cascade direction."

The present morphologic trends may be a reflection of continued weakness in younger rock units along pre-established structural alignments. The further study of the se linear features may bring new light to buried structures in the older rocks now covered with volcanics.

The preferred northwest orientation of the physiographic alignments is not in itself conclusive evidence for interpretation of the geologic structure. This statistical analysis method is intended as a 
preliminary indicator of probable structural features to guide geologic studies. However, the consistency and parallelism of geologic and seismic alignments strengthen the interpretation that it represents a geologic structural trend of major significance. 


\section{GEOLOGICAL INVESTIGATIONS}

Geologic data was derived primarily from previous investigations, namely, Trimble (1963) and well logs on file at the office of the Oregon State Engineer, Salem, Oregon. The local geology and structure are briefly described in Appendix II. Appendix VI contains 50 of the deepest and most representative of the well logs used in constructing the geologic cross sections, figures 19 through 25 in map pocket. The drillers' logs have been interpreted for formational separation and edited for clarity of teminology and composition. The wells described in Appendix VI are located in figure 2.

Lithologic differences used in recognition of Miocene and Pliocene formational contracts are important to show geologic horizons in construction of the geologic cross sections. The depth of the Miocene Columbia River basalt is important to this investigation because the gravity and magnetic anomalies are based upon its presence below ground surface. The post Troutdale formations are primary indicators of recent rejuvenation of the Clackamas River. The well logs provide good data on the Pliocene units and their contacts, but poor data on the Columbia River basalt due to too few deep wells penetrating into the basalt. 


\section{GEOPHYSICAL METHODS}

\section{Gravimetric}

Gravimetric information was obtained from six gravity traverses with a total of 166 gravity stations. A Worden gravity meter was used to test the possible presence of a consistent gravity anomaly across the observed physiographic alignment along a line co-linear with the eastern front of the Portland Hills and the Clackamas River. It is believed that the existence of an anomaly in this locality could be due to either a fault or a steep fold in the Columbia River basalt.

Gravitational anomalies result from lateral variations in the gravitational pull of the earth caused by contrasting near-surface densities. Sedimentary rocks are usually less dense than igneous formations. Locally, the density of the Columbia River basalt is from 2.72 to 2.94 , averaging $2.84 \mathrm{gm} / \mathrm{cc}$ (data from Schlicker and Deacon, 1967). The sedimentary formations are estimated to be less than $2.4 \mathrm{gm} / \mathrm{cc}$.

To use the gravity data for structural interpretation a series of corrections must be performed to correct for the station elevation, local topography, latitude, and instrument drift. The correction 
procedure is discussed in Appendix II - Gravity Reductions, and the corrected values are presented in Appendix III and shown graphically in profile on figures 19 through 25 in map pocket.

\section{Magnetic}

Magnetic data was obtained on three traverses with a total of 50 magnetic stations. A fluxgate magnetometer was used to examine the topographic alignment for a possible consistent magnetic anomaly.

All rock masses and rock types vary in their magnetic susceptibility due primarily to their content of magnetite and ilmenite. The magnetic susceptibility of sedimentary rocks is small as compared to igneous rocks (Dobrin, 1960). The existence of a magnetic anomaly in the investigated area would probably be due to change in depth of occurrence of the Columbia $R$ iver basalt rather than to geometric changes in the overlying sedimentary rocks. It is possible, however, that an irregular distribution of magnetite in the overlying sedimentary units may alter the magnetic anomaly due to the Columbia River basalt.

The magnetic data has been corrected for diurnal fluctuations by applying the closed loop method as discussed under drift corrections for the gravity measurements. The corrected values are listed in Appendix IV and shown graphically in profile in figures 20,24 , and 25. 


\section{IN TER PRETA TIONS}

Physiographic and structural alignments, geological relationships, gravity data, and magnetic data are analyzed for the possible existence of a structural feature aligned with the Clackamas River and the eastern front of the Portland Hills.

\section{Physiographic and Structural Alignments}

Physiographic alignments are significant in the Portland area as shown by the agreement with known structural trends. The degree of reliability of the physiographic alignments is dependent upon the unbiased and representative physiographic sample and the representation of known structure. It is my opinion that it would be difficult to bias the physiographic alignment selection by more than $5 \%$. Furthermore, I expect that the known structure is not biased for any orientation.

The physiographic rose-type diagrams, figures 6 and 9, show that of all the physiographic alignments $50 \%$ represent the general northwest trend; nearly $25 \%$ represent the N. $20^{\circ} \mathrm{W}$, and the N. $40^{\circ}$ W. trend; and $21 \%$ represent other secondary trends, namely, the N-S, E-W, and N. 50-60 E. The prominent northwesterly trend is 


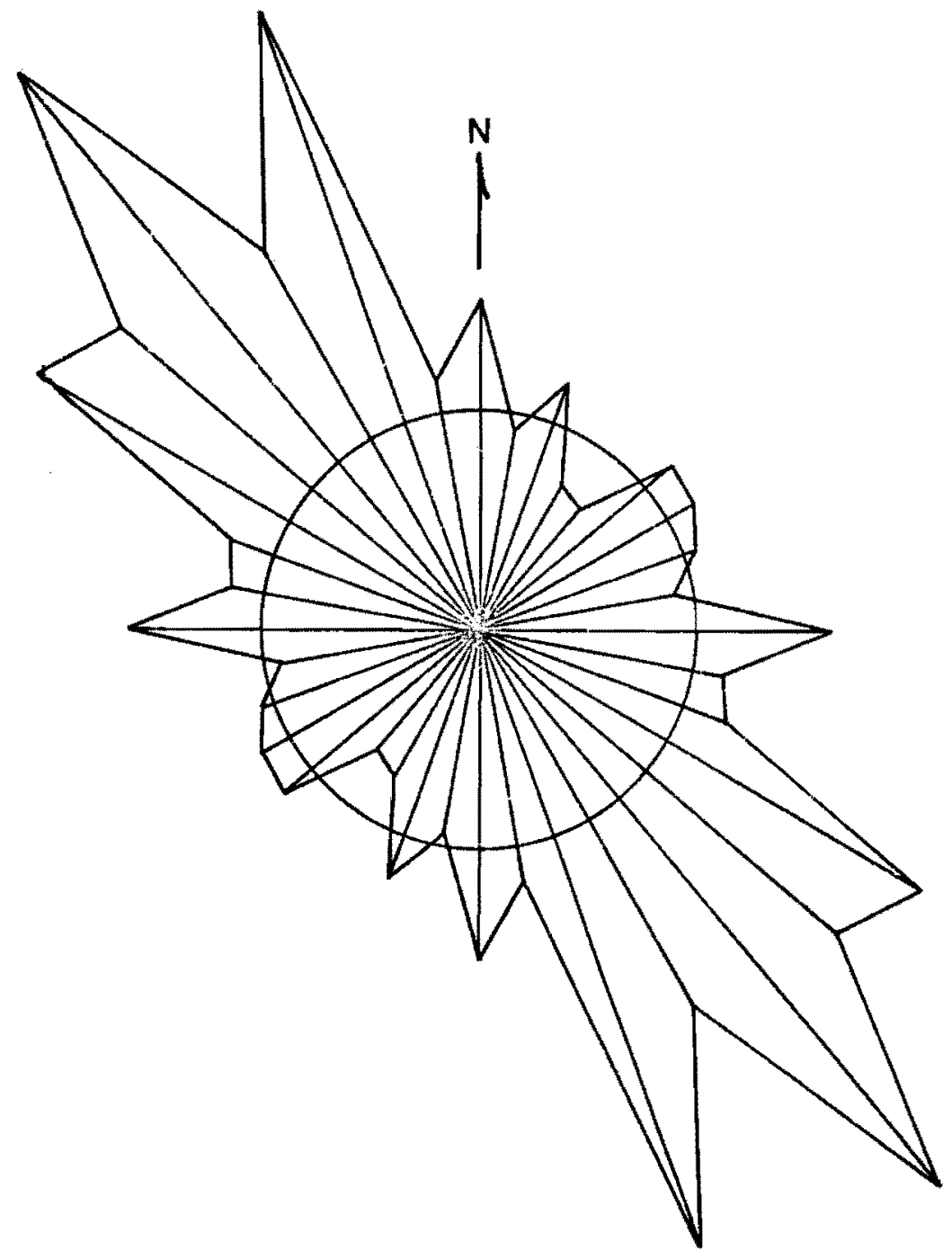

Figure 9. Summary of all orientation-length distribution of physiographic alignments. Area within the circle represents the area of random alignment orientation. Scale: 1 inch $=4 \%$. 
present even in the quadrangles nearest the west flank of Mt. Hood where a dominant east-west trend is expected from consequent drainage. Due to the consistency and prominence of the northwesterly morphologic trends a reliably strong structural framework orientation is indicated in the Portland area.

The physiographic alignments are a secondary effect caused by differential erosion. However, the consistency and prominence of the physiographic alignment trends strongly suggest that they are very good indicators of underlying structural features.

The trend significance is further confirmed by exposed and mapped structural alignments which are directly observed with which physiographic alignments can be compared. Even though in the Portland area most faults are poorly exposed, approximately $60 \%$ of the known mapped faults and fold axes concur with the dominant northwest physiographic trend (Schlicker, Deacon, and Twelker, 1964; Schlicker and Deacon, 1967).

A locally prominent underlying structural feature is suggested by the dominant northwest trends. Surficial units reflect continued weakness along pre-established structural trends, possibly the Oligocene Calkins Range. 


\section{Geologic Thickness Relationships and Gravity Profiles}

The lower Clackamas River area is made up of a sequence of Tertiary volcanics and terrestial sediments capped by Quaternary mudflows, terrace and channel deposits.

Geologic cross sections, figures 19 through 25 in map pocket, were drawn along the lines of the gravimetric and magnetic traverses to reconstruct the underlying geologic structures from well logs and maps in an attempt to test the possibility of offset in units along the alignment. Data available from well $\log s$ is not sufficient in itself to determine conclusively the nature of the subsurface structure along the alignment. The cross sections have been constructed from Trimble's (1963) geologic map, figure 15, and from well data, Appendix VI.

All gravity and magnetic traverses, except that of the Redland traverse, are suitably located to define the gravimetric characteristics of the physiographic alignment. The Redland traverse crosses the structural trend more obliquely than the other traverses. The gravity and magnetic profiles are plotted above the geologic cross sections, figures 19 through 25 , so the underlying structural configuration, where known, may be compared to the corresponding anomaly.

The gravity measurements are sensitive to changes in depth of 
the denser Columbia River basalt and are considered significant. The gravity interpretations below are made for the entire area of study and are also made on individual traverses. The basic limitations are discussed in Appendix II.

Negative Bouguer anomalies observed in all six gravity traverses show the influence of low density Cascade Range volcanic rocks in causing a $2.5 \mathrm{milligal} / \mathrm{mile}$ decrease in gravity to the southeast, figure 10 (Berg and Thiruvathukal, 1967b). This eastward decrease in gravity can indicate either an eastward thickening of the crust or a less dense crust and/or a mantle of low density (Berg and Thiruvathukal, 1967c). The gradient extends southeastward from approximately -15 milligals in the Milwaukie area to approximately -65 milligals near Estacada, a distance of about 20 miles. The Bouguer values obtained in this survey are in general agreement with the Oregon gravity map (Berg and Thiruvathukal, 1967b). Isostatic and regional gravity analysis are beyond the scope of this investigation.".

The traverses are discussed in order from the Milwaukie traverse, in the northwest, to the Estacada traverse, in the southeast.

Milwaukie traverse (figure 19 - in map pocket)

The water wells drilled in the abandoned Clackamas River channel are not normally deep enough to penetrate through the Sandy 


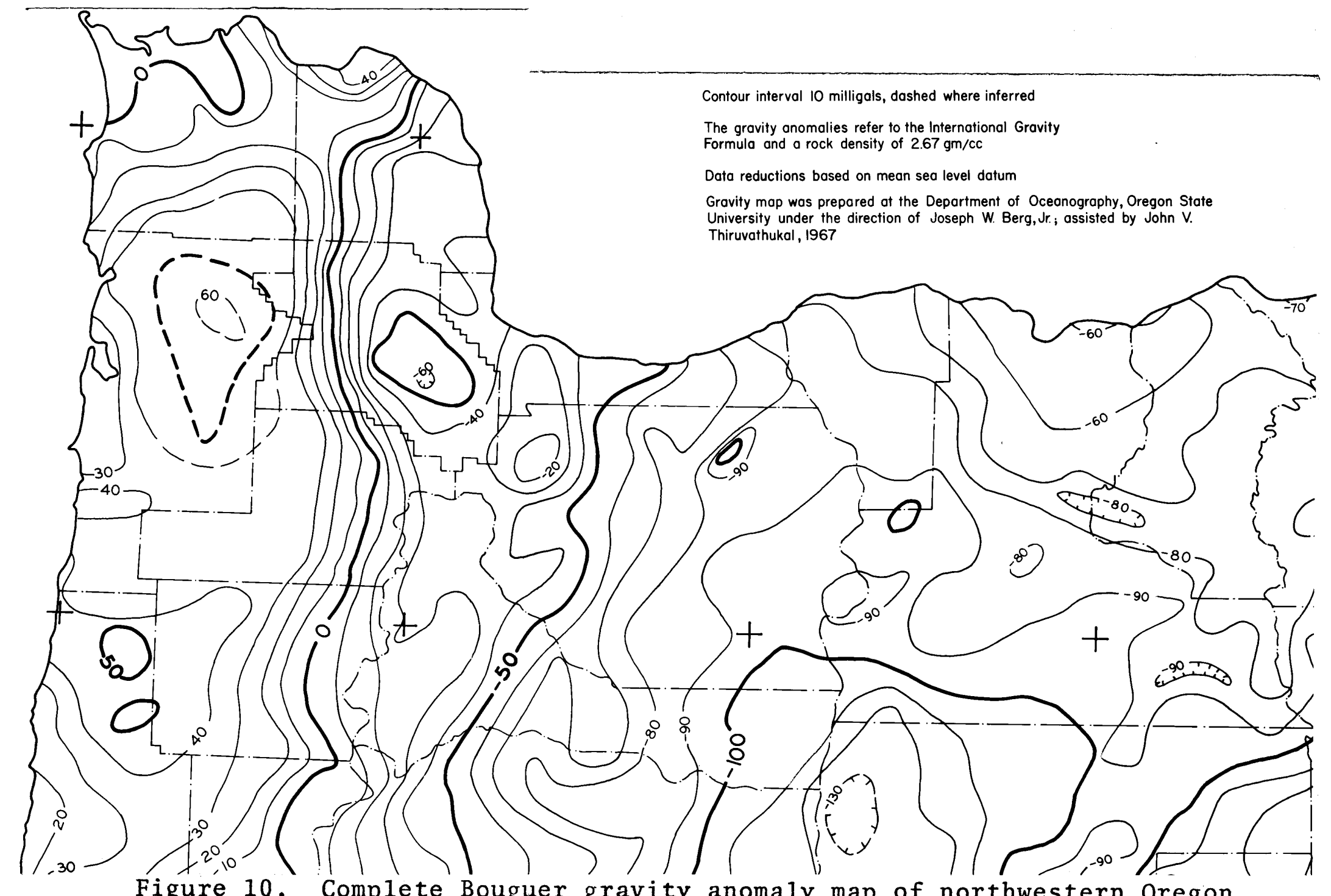

Figure 10. Complete Bouguer gravity anomaly map of northwestern Oregon (after Berg and Thiruvathukal, 1967b). No scale. 
River mudstone into the Columbia River basalt, the formation which would most clearly reflect the presence or absence of a fault or fold. However, the well logs display an apparent offset of the surface of the Sandy River mudstone. The Omark Industries, Inc. well (1/2-31Pl) penetrates the Sandy River mudstone at a depth of approximately 190 feet below sea level whereas the Camillo Giacchero well (2/11A) penetrates the mudstone at a depth of approximately 5 feet above sea level. The offset of the mudstone might also be caused by erosion by the Clackamas River and not entirely by faulting or folding. Well logs do indicate the presence of the Columbia River basalt near the landsurface between Kellogg Creek and Waverly Heights. This suggests that the Portland Hills fault lies on the eastern edge of Waverly Heights.

The steep gravity gradient of 3.74 milligals/0. 2 mile across the physiographic alignment indicates that the Columbia River basalt is either dipping steeply to the northeast or has been faulted down to the east at this location. Shapes of various typical gravity anomalies with their corresponding geometric subsurface structural forms are illustrated in figure 11 , numbers 1 and 2 would correspond to the above mentioned geometric forms. A fault and a steep fold may have similar gravity anomalies. Balsillie and Benson (1971) present evidence favoring faulting in the Columbia River basalt as the cause of the linear escarpment along the Portland Hills. Their study 


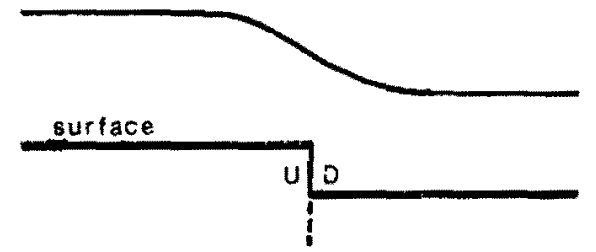

1 Vertical fault

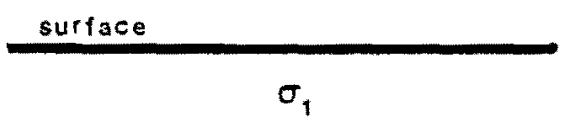

3 Homogeneous mass

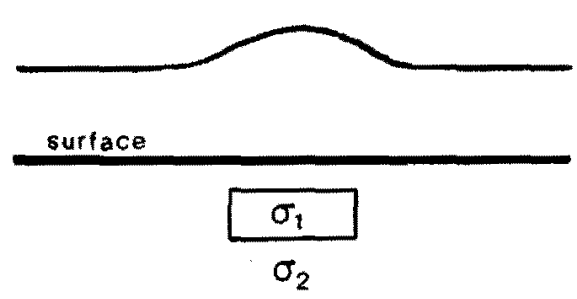

5 More dense body $O_{1}>O_{2}$

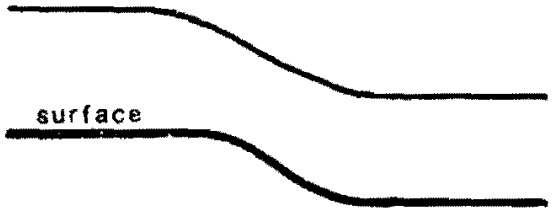

2 Steep fold

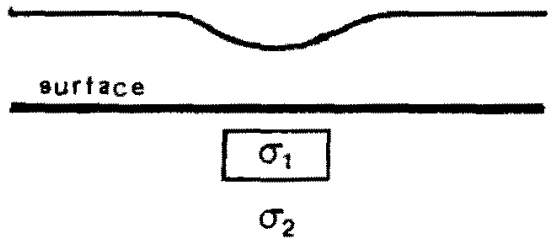

4 Less dense body $\sigma_{2}>\sigma_{1}$

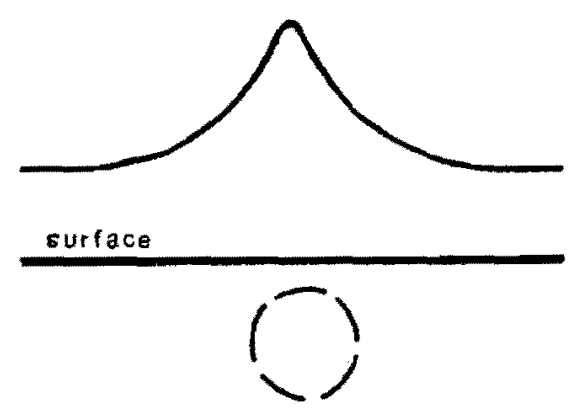

6 Horizontal cylinder

Figure 11. Graphic representation of various gravity anomalies and corresponding geometric forms (Dobrin, 1960; Lahee, 1961). 
utilized structural interpretation of columnar jointing to determine bedding plane orientation.

The precise location of the underlying structural offeet is que stionable. From the observed gravity gradient, the structural offset would be placed in the vicinity of station 2. However, additional data by an extension of the gravity traverse to the northeast might move the placement of the feature up to 0.2 mile to the northeast. Well logs also allow placement of the offset up to 0.2 mile to the northeast. The Portland Hills fault is not co-linear with Kellogg Creek, but Kellogg Creek is very straight and is parallel to the Portland Hills fault so I think it is possible that a minor branch fault parallels the creek.

Rock weakness along this segment of the Portland HillsClackamas River fault may form a zone of weakness followed by the abandoned channel of the Clackamas River. The apparent offset of the lower Pliocene Sandy River mudstone suggests movement as recent as middle Pliocene. This date, however, is strictly speculative.

Gladstone traverse (figures 12 and 20 - in map pocket)

The Gladstone traverse shows an apparent offset of the Troutdale formation and the Sandy River mudstone. In this locality the Sandy River mudstone may be offset as much as 120 feet as shown by 


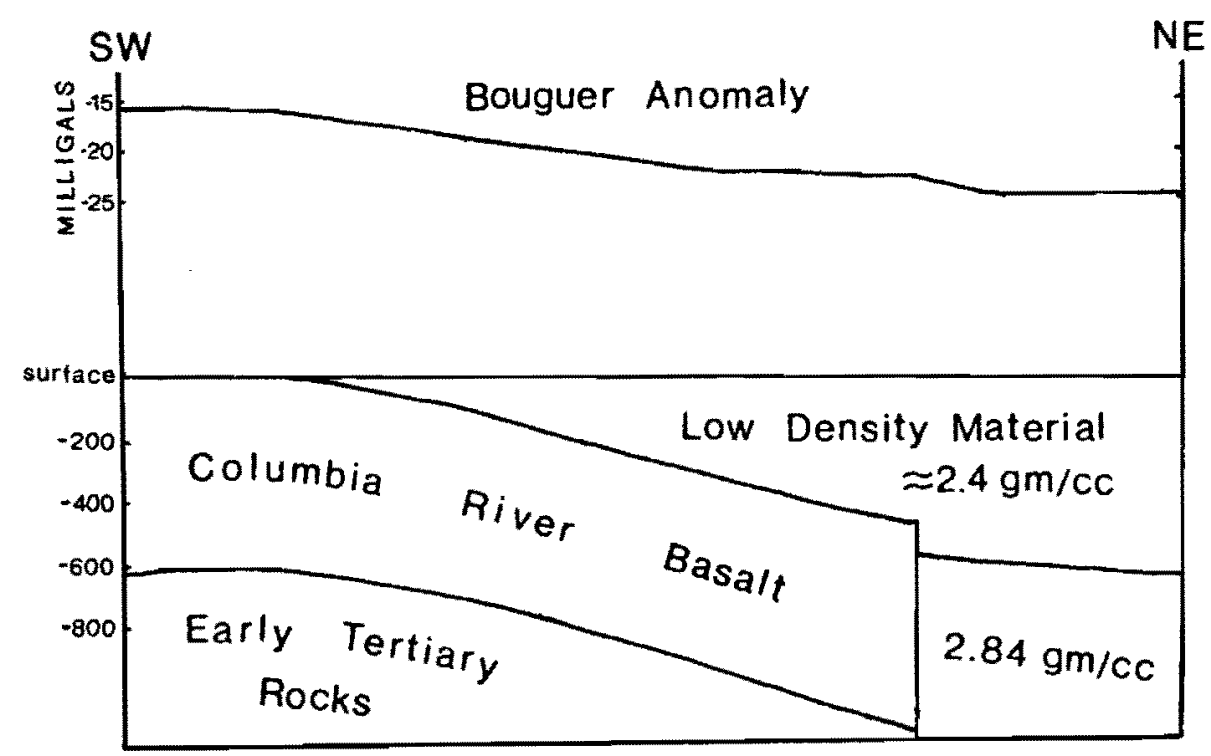

Figure 12. Graphic representation of one interpretation of the Bouguer gravity anomaly to geologic structure as seen in the Gladstone traverse. 
the following wells: Byrum W. Morehouse (2/2-15D), Donald Hugart (2/2-16K), and Oak Lodge Water District (2/2-16K3). A possible fault or fold is indicated by the well $\log$ data.

The form of the gravity gradient between stations 4 and 5 , at 1.45 milligals/0.1 mile, is suggestive of a fault or fold in which the Columbia River basalt was downdropped to the east. Movement of a fault may have caused the offsetting of the Troutdale formation and the Sandy River mudstone as indicated in the geologic cross sections.

$\underline{\text { Redland traverse (figure } 21 \text { - in map pocket) }}$

The Redland traverse does not show any definite geologic data from well logs to indicate the presence or absence of a structural fold or fault. Interpretation of the Bouguer anomalies is also tenuous due to the obliqueness of the traverse with respect to the main structural trend.

The Bouguer anomaly does show, however, two distinct levels, one approximating -40.5 milligals (stations $1-14)$ and the other approximately -39.5 milligals (stations $15-29$ ), which may reflect the underlying structure. By projecting the probable structural zone established by the Milwaukie and Gladstone traverses and that observed in the Transmission Line traverse to the Redland traverse, stations 14-16 would lie along the projected structural zone.

The consistent gravity anomaly which occurs across the 
physiographic alignment is reversed at this location. The gravity gradient dips to the south, thus suggesting the southern block was downdropped on the west. More gravity measurements are needed to determine the actual gravity distribution at this location and to allow a more conclusive interpretation.

Transmission Line traverse (figure 22 - in map pocket)

No definitive geologic data was obtained from well logs to indicate the presence or absence of a structural fold or fault along the physiographic alignment.

Several irregular gravity anomalies are shown in the Bouguer anomaly profile. The irregular appearance of the gravity profile between stations 21 and 31 is probably influenced by a combination of errors from the elevation corrections and from over compensation of the terrain correction values. There is no obvious geologic feature present which might explain the anomalies. There may be a Boring vent or dike concealed at depth.

An anomaly is defined between stations 10 and 13 , just east of Clear Creek. A 3.0 milligal change in the observed gravity gradient is consistent with the other anomalies along the structural alignment. The gradient suggests a fault or fold between stations 11 and 12 with the Columbia River basalt downdropped on the east. 
Paradise Park traverse (figure 23 - in map pocket)

The Paradise Park traverse lacks any subsurface geologic evidence for a fault or fold. The well logs indicate the general area where the Columbia River basalt dips below the Rhododendron formation. The approximate location of this interface is below station 23 . Absence of the Troutdale formation on the eastern edge of the traverse is due to erosion by the Clackamas River prior to the deposition of the Estacada formation.

The Bouguer anomalies west of station 15 reflect probable sources of error from the elevation corrections rather than an irregular gravity distribution caused by the Columbia River basalt or by near surface Boring dikes.

A change in the gravity gradient is seen east of station 15 , amounting to approximately a 1.5 milligal drop on the east ide of the physiographic linearity. This suggests that the eastward side has been downdropped by a fault or fold.

Estacada traverse (figure 24 - in map pocket)

The well logs located near the Estacada traverse show no physical evidence for the existence of a structural fault or fold. One well, the S. S. Dunlop $(3 / 4-21 \mathrm{cb})$, penetrated into the Columbia River basalt at a depth of approximately 300 feet below sea level. A steep gravity gradient of 2.46 milligals/0.25 mile across the 
physiographic alignment indicates that the Columbia River basalt either has been faulted or folded in the vicinity of station 9 and 10. The Bouguer anomaly suggests that the basalt has been downdropped east of station 8 .

\section{Significance of the Geologic Cross Sections and the Bouguer Anomalies}

The geologic cross sections across the fault-like linearity from well logs generally lack any definitive data which may explain the nature of the alignment. However, the Milwaukie and Gladstone traverses do indicate the possible presence of a fault. Structural features cannot be confirmed or precisely located using presently available well log information alone.

Two gravity features are indicated by the Bouguer anomalies. The first is the more regional anomaly of a steadily westward decreasing negative anomaly that suggests a westward rising of the Columbia River basalt. This conclusion is supported by well log data.

The second feature is the consistency of the size and shape of the gravity gradients which average 2.18 milligals $/ 0.2$ mile, downdropped to the east, across the physiographic alignment. Its alignment and consistency of direction and size define the zones of a possible fault or steep fold. A composite Bouguer anomaly which 
corresponds to the possible structural zone is illustrated in figure 13. The fault-like physiographic alignment is co-linear with the apparent offset of the Columbia River basalt as seen in the gravity profile. It is concluded, therefore, that the topographic linearity is most probably a reflection of a structural feature in which the Columbia River basalt is downdropped to the east.

\section{Magnetic Profiles}

All magnetic traverses cross the Portland Hills-Clackamas River alignment, figure 3. Simple interpretations of the magnetic anomalies are made for each traverse. The magnetic anomalies can be indicators of the underlying geologic structure associated with the alignment. Typical magnetic anomalies with their corresponding subsurface geometric forms are illustrated in figure 14 . The anomalies show a consistent magnetic break across the alignment. The cause of this change in gradient is not undergtood.

The traverses are discussed from the northwest to the southwest. The traverses discussed are the Gladstone-M, Fischers Mill$M$, and the Estacada-M traverses.

Gladstone-M traverse (figure 20 - in map pocket)

A steep magnetic gradient of nearly 80 gammas/0.25 mile is shown on the right hand side of the profile, stations $2-5$. The 


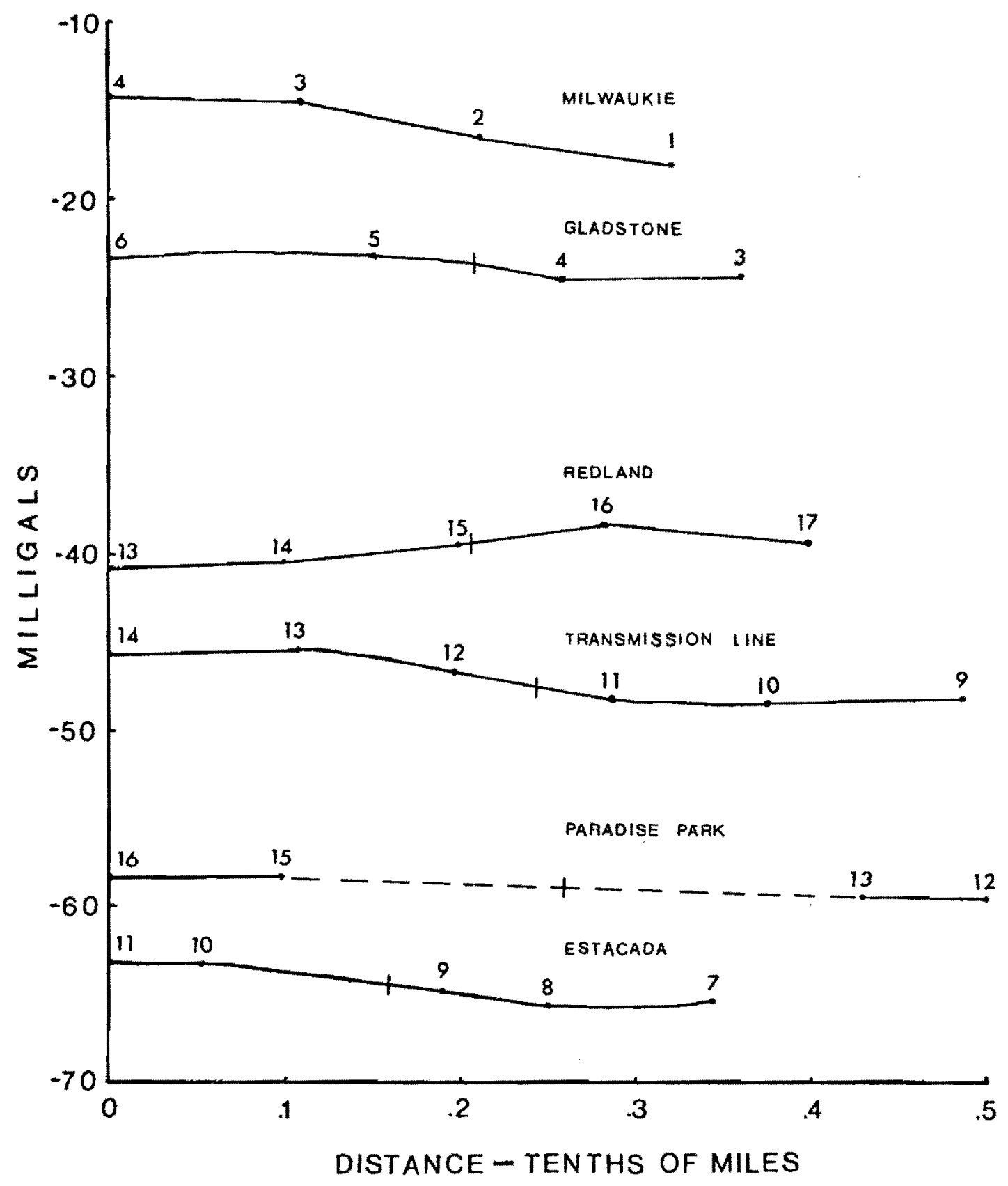

Figure 13. Composite Bouguer anomaly corresponding to the structural zone. Its central locality is marked by "I". 


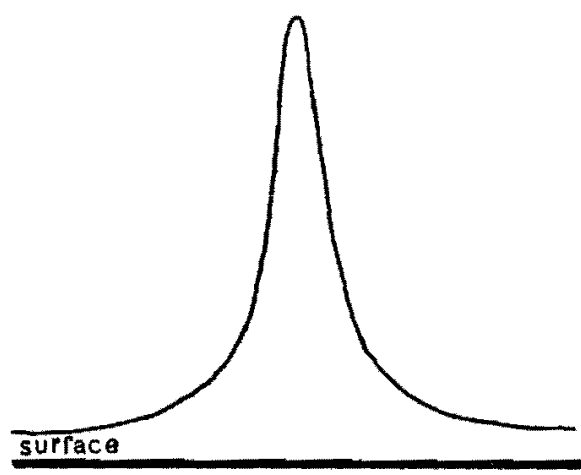

9

1 Vertical body

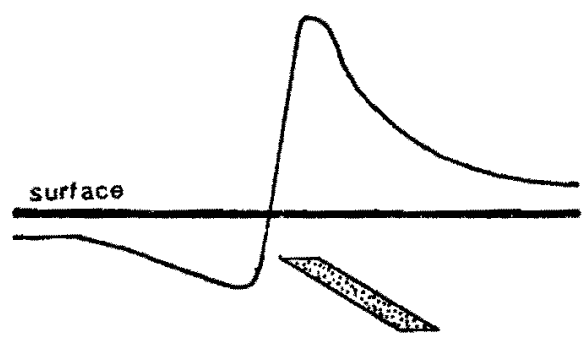

3 Inclined body

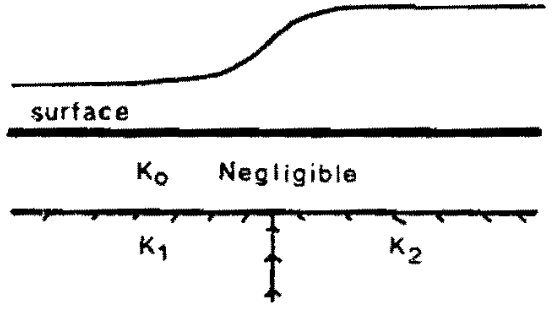

2 Contrasting rock types $k_{2}>k_{1}$

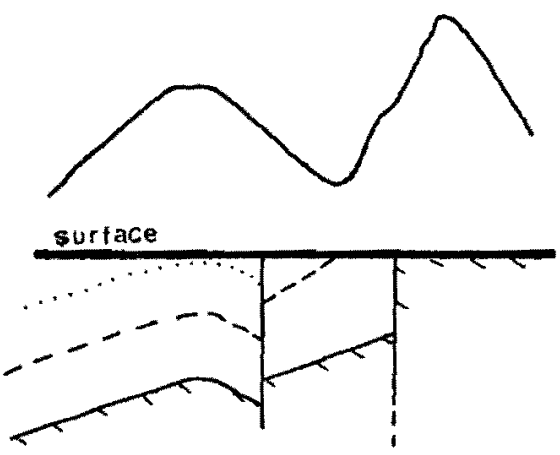

4 Irregular section

Figure 14. Graphic representation of various magnetic anomalies and corresponding geometric forms (Dobrin, $1960)$. 
anomaly is consistent with a Boring dike located approximately 500 feet below landsurface, figure 14, number 3.

The irregular nature of the profile found between stations 7 through 15 may indicate several breaks in the Columbia River basalt. The nature of these breaks is not known. The Columbia River basalt appears to be downdropped to the east from a combination of magnetic and gravity data.

Fischers Mill-M traverse (figure 25 - in map pocket)

The Fischers Mill-M traverse indicates a sharp gradient of nearly 615 gammas/0.4 mile between stations 2 and 6 . The cause of the abrupt change in the magnetic gradient is unknown. The magnetic anomaly, at station 6, however, is consistent with the location of the physiographic alignment.

Estacada-M traverse (figure 24 - in map pocket)

Several single point anomalies are observed in the magnetic profile, stations 10,11, 14, and 15. The cause of the anomalies is unknown. They could reflect a locally buried body with reversed magnetic polarity in relation to the surrounding rock.

The consistent magnetic anomaly which occurs across the Portland Hills-Clackamas River alignment is seen between stations 7 and 13. This change in gradient, approximately 900 gammas/0. 15 mile, is apparent when a smooth curve is drawn to fit the magnetic 
stations, excluding the point anomalies. The magnetic gradient suggests a structural feature co-aligned with the physiographic alignment.

\section{Significance of the Magnetic Anomalies}

The magnetic anomalies show a consistent change in the magnetic gradient across the physiographic alignment which defines a structural zone of unknown nature, possibly a fault. 


\section{CONCLUSIONS AND RECOMMENDATIONS}

The physiographic and structural alignments are significant indicators of underlying geologic structures. The consistency of the dominant northwest trend, N. $20^{\circ}$ W. and N. $40^{\circ}$ W., is observed over the entire area studied. The trend is considered to be a reliable structural indicator because the known faults and fold axes also present a matching dominant northwest orientation when statistically plotted.

It is believed that a major regional fault system probably exists along Portland Hills-Clackamas River alignment which may possibly extend as far to the southeast as the Steens Mountains. The dominant northwest trend of the co-alinear regional physiographic and structural alignments suggests the existence of the fault system.

The dominant local northwest trends are suggestive of under lying geologic features remnant from the Oligocene Calkins Range. The alignments, including the secondary northeast trends, may reflect continued or renewed weakness along these pre-established structural alignments.

The geologic cross sections developed from map and well data 
are considered to be as accurate as present data permits. The cross sections, however, do not present any tangible evidence as to the nature of the physiographic alignment.

The gravity traverses present a consistent and reliable indicator of an underlying structural feature corresponding to the physiographic alignment. The consistency of the size and shape of the Bouguer anomalies across the alignment defines the zone of a possible fault or steep fold developed in the Columbia River basalt. I tend to lean to the fault interpretation rather than a fold due to supporting evidence from seismic first motion analysis and by data presented by Balsillie and Benson (1971).

The magnetic anomalies further indicate the probable underlying geologic structure associated with the alignment. A consistent magnetic break occurs across the physiographic alignment.

In general, the various types of data have good consistency. The consistency strengthens their reliability as a structural indicator. The precise location of the observed structural feature is uncertain. The study establishes a probable zone in which a structural anomaly exists.

\section{Recommendations}

The area studied is not gravimetrically complex. The gravity profiles of this investigation indicate that much more subsurface 
information could be obtained from a more detailed gravimetric study of the Portland basin. The making of a gravity map with a contour interval of less than 5 milligals would probably define the underlying structure of the basin.

The magnetic profiles indicate much surface noise caused by local cultural features. It is suggested that an airborne magnetometer might better be used to construct a magnetic map of the area.

The analysis of the physiographic and structural alignments should be extended to include the entire state of Oregon. Their statistical analysis would contribute needed information to direct further geologic studies. 


\section{REFERENCES CITED}

Allen, V. T., 1948, Formation of bauxite from basaltic rocks of Oregon: Econ. Geology, v. 43, no. 8, p. 619-626.

Allison, I. S., 1932, Spokane flood south of Portland, Oregon [abs]: Geol. Soc. America Bull, v. 43, no. 1, p. 133-134. 1933, New version of the Spokane flood: Geol. Soc. America Bull., v. 44, no. 4. p. 675-722.

1935, Glacial erratics in Willamette Valley: Geol, Soc. America Bull., v. 46, no. 4, p. 615-632.

Baldwin, E. M., 1957, Drainage changes of the Willamette River at Oregon City and Oswego, Oregon: Northwest Sci., v. 31, no. 3, p. $109-117$.

1964, Geology of Oregon, 2d ed.: Ann Arbor, Mich., Edwards Bros., Inc. (distributed by Univ. of Oregon Cooperative Book Store, Eugene, Oreg. ), 165 p.

Balsillie, J. H., and Benson, G. T., 1971, Evidence for the Portland Hills fault: The Ore Bin, v. 33, no. 6, p. 109-118.

Berg, J. W., Jr., and Baker, C. D., 1963, Oregon earthquakes, 1814 through 1958: Seismol. Soc. Am. Bull., v. 53, p. 95108. (Condensation in The Ore Bin, v. 24, no. 9, p. 143-149, 1962.)

Berg, J. W., Jr., and Thiruvathukal, J. V., 1965, Gravity base station network, Oregon: Jour. Geophys. Research, v. 70, p. $3325-3330$.

1967a, Free-air gravity anomaly map of Oregon: Oregon Dept. Geology and Mineral Industries Map GMS-4a.

1967b, Complete Bouguer gravity anomaly map of Oregon: Oregon Dept. Geology and Mineral Industries Map GMS-4b. 
Berg, J. W., Jr., and Thiruvathukal, J. V., 1967c, Regional gravity of Oregon: The Ore Bin, v. 29, no. 6, p. 120-126.

Blank, H. R., Jr., 1966, General features of the Bouguer gravity field in southwestern Oregon: U. S. Geol. Survey Prof. Paper 550-C, p. 113-119.

Bretz, J. H., 1925, The Spokane flood beyond the channelled scablands: pt. 2: Jour. Geology, v. 33, no. 3, p. 236-259.

1928, Bars of channeled scabland: Geol. Soc. America Bull., v. 39 , no. 3, p. 643-702.

1959, Washington's channeled scabland: Washington Div. Mines and Geology Bull. 45, 57 p.

Bretz, J. H., Smith, H. T. V., and Neff, G. E., 1956, Channeled scabland of Washington; new data and interpretations: Geol. Soc. America Bull., v. 67, p. 957-1047.

Bromery, R. W., and Snavely, P. D., Jr., 1964, Geologic interpretation of reconnaissance gravity and aeromagnetic surveys in northwestern Oregon: U. S. Geol. Survey Bull, 1181-N, p. N1-N13.

Couch, R., Johnson, S. and Gallagher, J., 1968, The Portland earthquake of May 13, 1968 and earthquake energy release in the Portland area: The Ore Bin, v. 30 , no. 10, p. 185-190.

Couch, R., and Lowell, R. P., 1971, Earthquakes and seismic energy release in Oregon: The Ore Bin, v. 33, no. 4, p. 61-84.

Darton, N. H., 1909, Structural materials in parts of Oregon and Washington: U. S. Geol. Survey Bull. 387,33 p., 9 pls.

Dehlinger, P., and Berg, J. W., Jr., 1962, The Portland earthquake of November 5, 1962: The Ore Bin, v. 24, no. 11, p. $185-188$.

Dehlinger, P., Bowen, R. G., Chiburis, E. F., and Westphal, W. H., 1963, Investigations of the earthquake of November 5 , 1962, north of Portland: The Ore Bin, v. 25, no. 4, p. 53-68. 
Diller, J. S., 1896, A geological reconnaissance in the northwestern Oregon: U. S. Geol. Survey 17 th Ann. Rept., pt. 3, p. $441-$ 520 .

Diller, J. S., and others, 1915, Guidebook of the Western United States, pt. D, The Shasta Route and Coast Line: U. S. Geol. Survey Bull. 614.

Dobrin, M. B., 1960, Introduction to geophysical prospecting: New York, McGraw-Hill Book Co., Inc., 446 p.

E1sey, R. C., 1955, Geology of Portland and vicinity: Geol. Soc. Oregon Country, Newsletter, v. 21, no. 4, p. 29-32. Continued in v. 21 , no. 5 , p. 39-42.

Gallagher, J. N., 1969, A method for determining the source mechanism in small earthquakes, with application to the Pacific Northwest region: Oregon State Univ. doctoral dissertation, $187 \mathrm{p}$.

Gilchrist, F. G., 1952, Clackamas River field trip: Geol. Soc. Oregon Country, Newsletter, v. 18, no. 9, p. 89-92.

Gutenberg, B., 1959, Physics of the earth's interior, New York, Academic Press Inc., 239 p.

Hammer, S., 1939, Terrain corrections for gravimeter stations: Geophysics, v. 4, p. 184-194.

Hayford, J. E., and Bowie, W., 1912, The effect of topography and isostatic compensation upon the intensity of gravity: U. S. Geol. Survey Spec. Pub. 10.

Heiland, C. A., 1968, Geophysical exploration, New York, Hafner Publishing Co., Inc., $1013 \mathrm{p}$.

Heinrichs, D. F., and Pietrafesa, L. J., 1968, The Portland earthquake of January 27, 1968: The Ore Bin, v. 30, no. 2, p. $37-40$.

Heiskanen, W. A., and Vening Meinesz, F. A., 1958, The earth and its gravity field, New York, McGraw-Hill Book Co., Inc., $470 \mathrm{p}$. 
Higgins, M. W., and Waters, A. C., 1967, Newberry caldera, Oregon: a preliminary report: The Ore Bin, v. 29 , no. 3 , p. $37-60$.

Hodge, E. T., 1933, Age of the Columbia River and lower canyon [abs] : Geol. Soc. America Bull., v. 44, pt. 1, p. 156-157.

1938, Geology of the lower Columbia River: Geol. Soc. America Bull., v. 49 , no. 6, p. 831-930.

Hogenson, G. M., and Foxworthy, B. L., 1965, Ground water in the east Portland area, Oregon: U. S. Geol. Survey WaterSupply Paper 1793, 78 p.

Kane, M. F., 1962, A comprehensive system of terrain corrections using a digital computer: Geophysics, v. 27, no. 4, p. 455462 .

Lahee, F. H., 1961, Field geology, New York, McGraw-Hill Book Co., Inc., Sixth Edition, 926 p.

Lowry, W. D., and Baldwin, E. M., 1952, Late Cenozoic geology of the lower Columbia River valley, Oregon and Washington: Geol. Soc. America Bull., v. 63, no. 1, p. 1-24.

Mackin, J. H., and Cary, A. S., 1965, Origin of Cascade landscapes: Washington Div. Mines and Geology Inf. Circ. 41, $35 \mathrm{p}$.

Nettleton, L. L., 1939, Determination of density for reduction of gravimeter observations: Geophysics, v. 4, p. 176-183.

1940, Geophysical prospecting for oil, New York, McGrawHill Book Co., Inc., 421 p.

1942, Gravity and magnetic calculations: Geophysics, v. 7, p. 293-310.

1954, Regionals, residuals, and structures: Geophysics, v. 19 , p. $1-22$.

Peck, D. L., Griggs, A. B., Schlicker, H. G., Wells, F, G., and Dole, H. M., 1964, Geology of the central and northern parts of the Western Cascade Range in Oregon: U. S. Geol. Survey Prof. Paper 449, 56 p. 
Ray, R. G., 1960, Aerial photographs in geologic interpretation and mapping: U. S. Geol. Survey Prof. Paper 373, 230 p.

Rinehart, W., Bower, R. G., and Chiburis, E. F., 1964, Airport gravity base station network in Oregon: The Ore Bin, v. 26, no. 3 , p. 37-56.

Sandberg, C. H., 1958, Terrain corrections for an inclined plane in gravity computations: Geophysics, v. 23, p. 701-711.

Schlicker, H. G., Deacon, R. J., and Twelker, N. H., 1964, Earthquake geology of the Portland area, Oregon: The Ore Bin, v. 26, no. 12, p. 209-230.

Schlicker, H. G., and Deacon, R. J., 1967, Engineering geology of the Tualatin Valley region, Oregon: Oregon Dept. Geology and Mineral Industries Bull. 60, $103 \mathrm{p}$.

Skeels, D. C., 1963, An approximate solution of the problem of maximum depth in gravity interpretations: Geophysics, v. 28, p. 724-735.

Snavely, P. D., Jr., and Wagner, H. C., 1963, Tertiary geologic history of western Oregon and Washington: Washington Div. Mines and Geology Rept. Inv. 22, 25 p.

1964, Geologic sketch of northwestern Oregon: U. S. Geol. Survey Bull. 1181-M, p. M1-M17.

Stauffer, J., 1956, Late Pleistocene flood deposits in the Portland area: Geol. Soc. Oregon Country, Newsletter, v. 22, no. 3, p. $21-31$.

Texas Instruments Incorporated, 1963, Worden gravity meter operating instruction manual n. 81537-5: Texas Instruments Inc., Houston, Texas, 89 p.

Thiruvathukal, J. V., and Berg, J. W., Jr., 1966, Gravity measurement program in Oregon: The Ore Bin, v. 28, no. 4, p. $69-75$.

Thiruvathukal, J. V., Berg, J. W., Jr., and Henricks, D. F., 1970, Regional gravity of Oregon: Geol. Soc. America Bull., v. 81 , no. 3 , p. $725-738$. 
Treasher, R. C., 1942a, Geologic history of the Portland area: Oregon Dept. Geology and Mineral Industries Short Paper 7.

1942b, Geologic map of the Portland area: Oregon Dept. Geology and Mineral Industries Geol. Map Series no. 7.

Trimble, 1957, Geology of the Portland quadrangle, Oregon and Washington: U. S. Geol. Survey Quadrangle Map GQ-104.

1963, Geology of Portland, Oregon and adjacent areas:

U. S. Geol. Survey Bull. 1119, 119 p.

Walker, G. W., and King, P. B., 1969, Geologic map of Oregon:

U. S. Geol. Survey, Map I-595.

Walker, G. W., 1969, Geology of the High Lava Plains province, in Mineral and water resources of Oregon: Oregon Dept. Geology and Mineral Industries Bull. 64, p. 77-79.

Warren, W. C., Norbisrath, H., and Grivetti, R. M., 1945, Geology of northwestern Oregon west of Willamette River and north of latitude $45^{\circ} 15^{\prime}$ : U. S. Geol. Survey Oil and Gas Inv. Map OM-42.

Washburne, C. W., 1914, Reconnaissance of the geology and oil prospects of northwestern Oregon: U. S. Geol. Survey Bull. 590, $111 \mathrm{p}$.

Wells, F. G., and Peck, D. L., 1961, Geologic map of Oregon west of the 121 st meridian: U. S. Geol. Survey Misc. Geol. Inv. Map I-325, scale 1:500, 000 .

Westphal, W. H., 1962, Seismic aftershock investigations--Project Vela, Portland, Oregon earthquake of November 6, 1962: Stanford Research Institute, Tech. Rept. 1, 11 p.

Williams, I. A., 1916, The Columbia River gorge: its geologic history interpreted from the Columbia River Highway: Mineral Resources of Oregon, Oregon Bur. Mines and Geology, v. 2 , no, $3,130 \mathrm{p}$.

Woollard, G. P., 1958, Results for a gravity control network at airports in the United States: Geophysics, v. 23, no. 3, p. 520-535. 
Woollard, G. P., and Rose, J. C., 1963, International gravity measurements: Soc. Explor. Geophysicists, Tulsa, Okla., 1963.

von Bandat, H. F., 1962, Aerogeology: Gulf Publishing Co., Houston, $350 \mathrm{p}$. 
APPENDICES 


\section{APPENDIX I \\ DESCRIPTION OF BENCH MARKS}

The following bench marks were used as base stations for the gravity traverses. See "B" in figure 2.

(1) City of Portland CLB bench mark \#679.

Location: SE corner of SE 13 th and SE Malden in Sellwood, Oregon.

Elevation: Not listed. Map gives it as 121 feet.

Use: Used as base station in the Milwaukie traverse.

(2) U. S. Geological Survey bench mark \#JX14 established in 1929 .

Location: Intersection of Wise Road and the Southern Pacific tracks near Clackamas, Oregon.

Elevation: Listed as 112.6 feet.

Use: Used as base station in the Gladstone traverse.

(3) U. S. Geological Survey bench mark PRIM TRAV ORE STA No. 4.

Location: $1 / 2$ block west of intersection of Redland Road and Grasle Road. Approximately $1 / 2$ mile west of Redland, Oregon.

Elevation: Listed as 527 feet.

Use: Used as base station in the Redland traverse and Transmission Line traverse.

(4) U. S. Geological Survey bench mark PRIM TRAV STA No. 17 established in 1910.

Location: In Fischers Mill, Oregon at left of gas station and behind chainlink fence (in private yard).

Elevation: Listed as 293 feet.

Use: Used as base station for part of the Paradise Park traverse. 
(5) U. S. Coast and Geodetic Survey bench mark Y429 established in 1946.

Location: In yard north of Currinsville, Oregon on Highway 211 . A concrete block rests upon the bench mark.

Elevation: Not listed. Map gives it as 451 feet. Use: Used as base station for part of Paradise Park traverse and all of the Estacada traverse. 
APPENDIX II

\section{GEOLOGY}

\section{Geologic Setting}

Geographically, the lower Clackamas River area is part of the northern Willamette Valley. The Willamette Valley extends westward to the Coast Range and eastward to the Cascade Range.

The Clackamas River is a major tributary of the Willamette River. It heads in the Cascade Range and flows northwestward to the Willamette River at Gladstone, approximately one mile north of Oregon City.

In early Eocene time the lower Clackamas River area was part of a 400 mile long eugeosynclinal trough (Snavely and Wagner, 1963). The Clackamas and Portland area has since undergone several periods of uplift and deformation. Following the extrusion of the Columbia River basalt in middle Miocene time, the area became a structural basin between the upwarped ancestral Portland Hills and Cascade Range (Hogenson and Foxworthy, 1965). The Sandy River mudstone was deposited in a lake which formed in the deepening basin. Deformation of the Portland Hills, Cascade Range, and 
secondary upwarps (Oatfield Heights ridge) continued as the Columbia River and other streams flooded the area depositing the alluvial gravels of the Troutdale formation (Trimble, 1963). An erosional surface developed on the Troutdale formation on which late Pliocene to late (?) Pleistocene Boring lava extruded in flows and formed volcanic cones.

Post-Boring alluviation began in early Quaternary time forming a piedmont plain of mudflows and gravels. Locally, the Clackamas River formed valleys which were subsequently partially filled with mudflows and gravel deposits (Trimble, 1963). Following the effects of the glacial Lake Missoula flood waters, the Clackamas River became fully entrenched. Tectonic uplift had a part in causing the rejuvenation of the Clackama's River and may still now be in progress. The recent rejuvenation, however, could also be caused by non-tectonic processes such as an increase in stream competency associated with glacial retreat and lowering of sea level.

\section{Stratigraphy}

The Miocene and Pliocene rocks, especially the Columbia River basalt, are important to this study because the gravity and magnetic anomalies are based upon the distribution of the basalt and because the recognition of formational units in drill logs is important in constructing geologic cross sections. Post-Troutdale formations 
are important to this study primarily as an indication of recent rejuvenation of the Clackamas $\mathrm{R}$ iver.

No rocks older than middle Miocene crop out in the geophysically investigated area. The Scappose formation or the Skamania volcanic series underlies the Columbia River basalt. Tertiary volcanic rocks include the above, and the Columbia River basalt, the Rhododendron formation, and the Boring lava. Other Tertiary rocks being of terrestial origin include the Sandy River mudstone and the Troutdale formation. Quaternary formations include the Springwater formation, the Gresham formation, the Estacada formation, and other recent terrace and channel deposits.(figure 15).

\section{Tertiary System}

$\underline{\text { Skamania Volcanic Series }}$

The late Eocene to early Miocene (?) Skamania volcanic series is composed of "altered basalt and basaltic andesite flows and associated pyroclastic rocks" (Trimble, 1963). The formation underlies the Scappoose formation and does not crop out in the geophysically investigated area or is it described in any of the well logs.

\section{Scappoose Formation}

The Scappoose formation is dated as late Oligocene to early Miocene age. Warren and Norbisrath (1946) describe it as a "gray, 


$$
\begin{aligned}
& \text { Qa1 - Alluvium } \\
& \text { Qt - } \begin{array}{l}
\text { Terrace } \\
\text { deposits }
\end{array} \\
& \text { Qs - } \begin{array}{l}
\text { Sand and silt } \\
\text { deposits }
\end{array} \\
& \text { Qe - Estacada } \\
& \text { formation } \\
& \text { Qg - Gresham } \\
& \text { formation } \\
& \text { Qsw - Springwater } \\
& \text { formation } \\
& \text { QTb - Boring lava } \\
& \text { Tt - Troutdale } \\
& \text { formation } \\
& \text { Tsr - Sandy River } \\
& \text { mudstone } \\
& \text { Tr - Rhododendron } \\
& \text { formation } \\
& \text { Tcr - Columbia River } \\
& \text { basalt }
\end{aligned}
$$

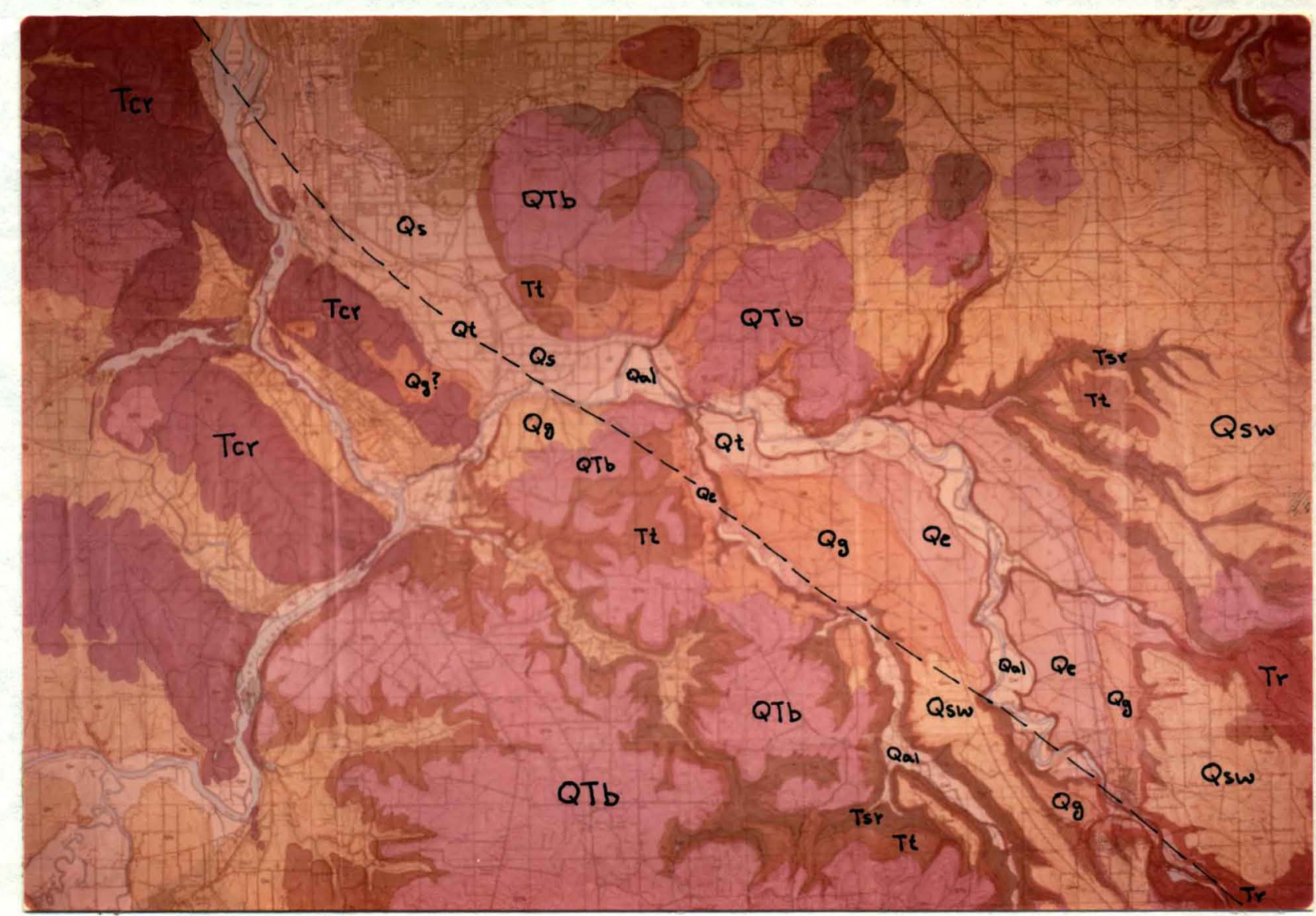

Figure 15. Geologic map of thesis area (Trimble, 1963). No scale. 
yellowish-weathering, firm, fossiliferous, sandy, tuffaceous shale and shaly sandstone, commonly spotted with pumiceous material." Being of sedimentary marine origin, the formation contains connate saline water (Hogenson and Foxworthy, 1965). The City of Gladstone well $(2 / 2-20 F 1)$ was drilled through the Columbia River basalt into a shale containing saline water at a depth of 620 feet below sea level. It is believed that the well bottoms in the Scappoose formation.

\section{Columbia River Basalt}

The middle Miocene Columbia River basalt is the oldest formation exposed in the lower Clackamas River area. In the investigated area the basalt crops out only in the Oatfield Heights ridge and Waverley Heights. The Portland Hills has well exposed outcrops. Oatfield Heights and the Portland Hills are anticlines comprised of Columbia River basalt and older rocks.

The petrologic features of the Columbia River basalt are discussed by Trimble (1963) and Peck, and athers (1964). Weathered Columbia River basalt produces a yellowish-brown to a reddish-gray brown soil. V. T. Allen (1948) determined that local weathering occurs in places to depths of 170 feet. Average specific gravity taken from several quarries comprised of Columbia $R$ iver basalt is 2. $84 \mathrm{gm} / \mathrm{cc}$ (data from Schlicker and Deacon, 1967, p. 74-75). Thickness of the Columbia River basalt varies with location. 
Lowry and Baldwin (1952) have determined the thickness to be as much as 1000 feet in the Portland area. A well drilled by the Richfield Oil Company in the Portland Hills (SW1/4 sec. 23, T. 1 N., R. 1 W.) penetrated between 700 and 800 feet of Columbia River basalt (Balsillie and Benson, 1971). The greatest drilled thickness in the geophysically investigated area is about 610 feet of Columbia River basalt as seen from a well drilled for water by the City of Gladstone (2/2-20F 1$)$.

Stratigraphically, the Columbia River basalt unconformably overlies the Scappoose formation and the Skamania volcanic series and unconformably underlies the Sandy River mudstone in the vicinity of Gladstone, and the Rhododendron formation near Estacada.

\section{$\underline{\text { Rhododendron Formation }}$}

The Rhododendron formation in the lower Clackamas River area is exposed along the Clackamas River southeast of Estacada. It is dated as middle to late Miocene by stratigraphic position and by plant fossils.

Locally, the Rhododendron formation consists of marginal volcanic mudflow breccia with lava flows intertonguing eastward (Trimble, 1963). Weathering of the formation results in a yellowbrown to reddish-brown soil.

A water well drilled in 1963 for S. S. Dunlop (3/4-21N) infers 
a thickness of 752 feet of Rhododendron formation. The well terminates in Columbia River basalt. The formation is believed to strike to the northeast and dips less than 2 degrees to the northwest in the lower Clackamas River area (Trimble, 1963). Wells drilled for Ardel Zach (3/4-9F) and Glen H. Hill (3/3-13A or H) penetrate the top of the Rhododendron formation indicating an apparent dip of 5 degrees to the southwest (S. $70^{\circ}$ W.). See Paradise Park traverse in map pocket, figure 23.

\section{Sandy River Mudstone}

The Sandy River mudstone is early Pliocene in age. Its distribution is extensive in that the formation underlies most of the investigated area. Excellent exposures are found along the lower Clackamas River in what is now McIver State Park. Most exposures are heavily covered with vegetation and are distorted by slumping and landsliding.

Formational thickness varies depending upon locality. The maximum exposed thickness of the Sandy River mudstone in the studied area is 250 feet along the Clackamas River near Paradise Park. The formation thickens to the northwest from Estacada. A well drilled near Paradise Park for Glen $\mathrm{H}$. Hill (3/3-13 A or H) indicates nearly 270 feet of mudstone to be Sandy River. The log of a. well for Ernest Evanson (3/3-7M) shows 330 feet of strata to be 
Sandy River mudstone. The C. D. Carlson well (2/3-18J) infers

419 feet of Sandy River mudstone. This thickening to the northwest may indicate the east flank of the Willamette syncline.

The well logs indicate lithologic units of sand, shale, clay, and silty clay which may be classed as sandstone, mudstone, and siltstone. Clay and silt are the principal units. Typically, a blue or gray clay is the key horizon used in separating the Sandy River mudstone from the overlying Troutdale formation.

\section{Troutdale Formation}

The lower Pliocene Troutdale formation is distinguished from the Sandy River mudstone by its sandstone and conglomerate composition. The Troutdale formation consists mainly of sandstone varying in composition from a tuffaceous sandstone in the Estacada area to more of a micaceous, arkosic sandstone northwest of the investigated area (Trimble, 1963). The Troutdale formation is distinguished by its cemented gravels from the overlying uncemented channel or terrace deposits.

The thickness of the Troutdale formation varies with location and degree of erosion prior to the deposition of the Boring lava and Quaternary formations. The City of Milwaukie well (1/1-36A) infers a thickness of nearly 240 feet of strata to be Troutdale. Donald R. Smith's well (3/3-14aca) shows only 130 feet to be Troutdale. The 
formation thins toward the slopes of the Cascade Range.

\section{Tertiary and Quaternary Systems}

\section{Boring Lava}

Treasher (1942a) described and named the Plio-Pleistocene basaltic flows and pyroclastic rocks as the Boring lava. Eruptive vents are present north and south of the investigated area which is part of the Boring lava plain.

The Boring lava varies in thickness depending upon proximity to a source vent and the paleotopography. Generally, the lava ranges from a few feet to several hundred feet in thickness. A well drilled for Robert Kiefer (3/3-15bb) in 1970 infers a thickness of 270 feet to be Boring lava.

The Boring lava has been weathered from depths as much as 15 feet (Schlicker and Deacon, 1967) to depths more than 25 feet (Trimble, 1963). Petrologic features are discussed by Treasher (1942b), Trimble(1963), and Peck, and others (1964).

\section{Quaternary System}

\section{Springwater Formation}

The early (?) Pleistocene Springwater formation is a piedmont deposit composed of fluvial gravel with interstratified mudflow deposits which were developed prior to the Clackamas River 
entrenchment (Trimble, 1963). The Robert L. Poore well (3/4-28C) infers nearly 100 feet to be Springwater deposits.

\section{Gresham Formation}

The Gresham formation, a high-level flood plain deposit, is of middle (?) Pleistocene age. The formation consists mainly of bouldery gravely with mudflow phases which occur as terraces ranging from 300 to 500 feet in elevation. In several locations the formation is nearly 150 to 200 feet below the Springwater formation. Weathering has not been as complete for the Gresham formation, 35 feet, as the Springwater formation, 75 feet (Trimble, 1963). The Eugene C. Shore water well (3/4-29bcc) infers a thickness of 70 feet.

\section{Estacada Formation}

The third terrace deposit of late (?) Pleistocene age is the Estacada formation. It consists mainly of gravel and mudflow deposits which lie nearly 100 feet below the Gresham formation. Locally, a well $\log$ for Stuart Puckett (3/4-8M1) shows 60 feet of gravels. The E. L. Williams well $(3 / 4-7 Q)$ infers 42 feet to be the Estacada formation. The formation has weathered to a depth of 10 feet in the Clackamas River area (Trimble, 1963).

\section{Alluvium of Abandoned River Channel}

These sand, silt, and gravel deposits of late Pleistocene or 
Recent in age are present along the present Clackamas River channel and its abandoned channel that extends from Clackamas to Milwaukie. The deposits in the abandoned Clackamas River channel thicken to the northwest from a few feet, F. J. Mooney well (2/2-16B1), to more than 200 feet in the Omark Industries well (1/2-31 Pl).

\section{Recent Alluvium}

Recent alluvium occurs along the Clackamas River and Clear Creek mainly as gravel deposits with thicknesses less than 50 feet.

\section{Structure}

Broad synclines and anticlines typify the Portland-lower Clackamas River area. Surface evidence for faulting in the geophysically investigated area is lacking due to the recent volcanism, alluviation of the area, and thick soil cover.

The northwest-trending anticlinal ridges of the Portland Hills and Oatfield Heights ridges are the predominant surficial structural features in the area. Other northwest-trending anticlinal and synclinal systems exist to the west of the geophysically investigated area. Schlicker and Deacon (1964) believe that a major normal fault flanks the eastern side of the Portland Hills which also controls the channel of the Clackamas River. The possible existence of this fault has been substantiated by studies by Balsillie and Benson (1971). 
Additional evidence for the existence of the Portland Hills fault is presented and discussed in this report.

Outside of the investigated area Schilicker and Deacon (1964 and 1967) have mapped several northwest and northeast-trending normal faults. Northeast-trending faults have been suggested as the cause of other Portland earthquakes (Couch and others, 1968;

Heinrichs and Pietrafesa, 1968).

A broad synclinal downwarp shapes the lower Clackamas River area which is underlain by the Columbia River basalt. The basalt has been depressed to an inferred depth of about 60 feet below sea level in the approximate center of the Willamette syncline as mapped on the Geologic Map of Oregon West of the 121st Meridian--Tectonic Map (Wells and Peck, 1961). Farther north in the Portland area, the Ladd well (39th and Glisan Streets) shows the basalt on the west flank of the Willamette syncline to be depressed to a depth of 1070 feet below sea level.

Faults probably exist at depth which would displace the gently sloping Columbia River basalt. Hogenson and Foxworthy (1965) have indicated a possible buried fault which conceivably strikes N. $30^{\circ}$ E. in the vicinity of Regner Road, north of Sunshine Valley. 


\section{APPENDIX III}

\section{GRA VITY REDUCTIONS}

Gravity reductions are applied to the observed gravity so as to reduce the gravity to an arbitrary datum plane of a known latitude. This artificial condition will then show any variations in the reduced gravity which can be attributed to density variations. The corrections to be applied are: the free-air, the Bouguer, the topographic, namely, the latitude and the terrain, and the instrument drift. The datum plane for all reductions is mean sea level.

\section{Free-air Correction}

The free-air effect accounts for the difference in the gravity field between the gravity station and the datum plane due to differences in elevation only, that is, without regard to the intervening mass of material. A correction value for this vertical gradient of gravity is given by Nettleton (1940) and by Dobrin (1960) as 0.09406 milligals per foot. The theoretical value of $0.09406 \mathrm{~h}$, $\mathrm{h}$ being the distance in feet from the gravity station to the datum plane, was added to the observed gravity. 


\section{Bouguer Correction}

The Bouguer effect accounts for the material mass between the gravity station and the datum. A value of $0.01276 \sigma \mathrm{h}$ milligals per foot of thickness, where $\sigma$ is density and $h$ is the thickness of the $s$ lab, is given by Nettleton (1940).

The density factor is dependent upon the densities of the different lithologies found between the gravity station and the datum plane. An average density may introduce an error if contrasting lithologies occur in the area. Nettleton (1938) describes an indirect method in obtaining surface densities by reducing the observed gravity by different densities. The actual density is chosen by the smoothest reduced gravity profile. This survey, however, will use an average density of $2.67 \mathrm{gm} / \mathrm{cc}$, In assuming an average density the interpretation must be made keeping in mind that some of the observed anomaly may be attributed to a density contrast located above the selected datum plane.

The Bouguer correction is subtracted from the observed gravity in this survey because the station elevation is higher than the datum plane which produces a net increase in the gravity value due to the attraction of the material between the station and the datum plane.

The free-air correction and the' Bouguer correction may be 
combined into a total elevation correction of $(0.09406-0.01276 \sigma) \mathrm{h}$ or $0.060 \mathrm{~h}$ miligals, where $\mathrm{h}$ is the distance in feet above mean sea level, for a density of $2.67 \mathrm{gm} / \mathrm{cc}$ (Dobrin, 1960).

\section{Latitude Correction}

The "international gravity formula" for the variation of gravity with latitude is given by Dobrin (1960) as

$$
g=978.049\left(1+0.0052884 \sin ^{2} \phi-0.0000059 \sin ^{2} 2 \phi\right) g a l s
$$

where $\phi$ is the latitude.

The latitude correction was individually computed for each station by use of a computer. Listed below is the source program.

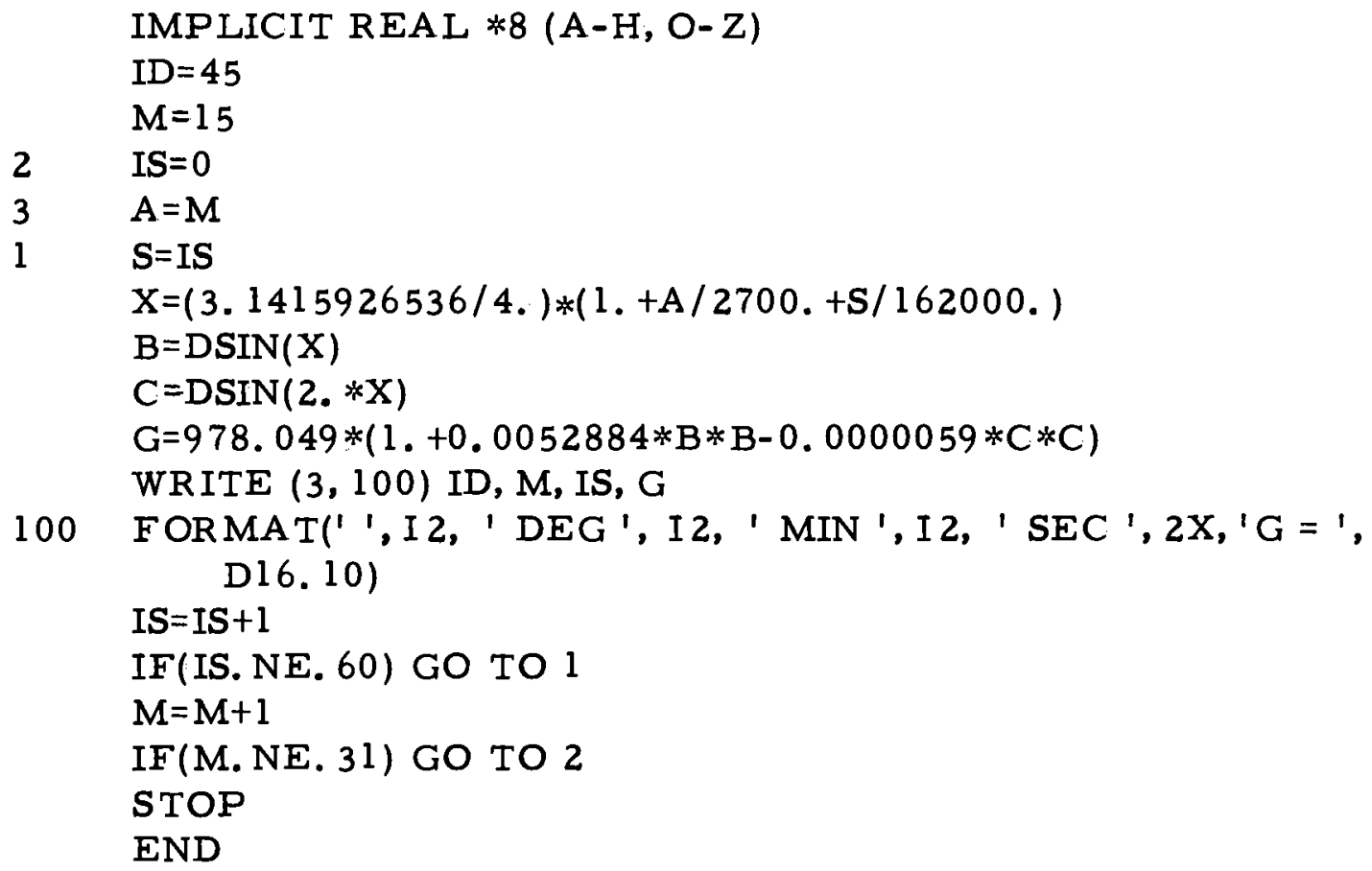

The computer program is written in Fortran IV. Double precision was used due to the large calculated gravity figure. No data 
cards are needed. The program is designed so that a starting $\phi$ may be written into the program (ID=degree, $M=$ minute, IS=second) with the resultant execution being printed out at one second intervals. Under the "free" operating limitations found at the computer facility at the University of Oregon no allowance for a predetermined final $\phi$ is written into the program. Minor revisions of the program would enable the operator to specify the $\phi$ for computer shut-down. Contained within the program is a routine which computes $\sin ^{2} \phi$ and $\sin ^{2} 2 \phi$ for each second.

The output was used for the theoretical gravity values required in the free-air and Bouguer anomalies.

\section{Terrain Correction}

The terrain correction is supplementary to the Bouguer correction by accounting for the vertical attraction of topography both above and below the station. The Bouguer correction assumes an infinite horizontal slab which is seldom the case. Points higher than the station have an upward gravitational component which opposes part of the gravitational pull of the earth. Depressions or valleys also account for a smaller gravitational pull at a given station than the Bouguer effect accounts for. It is therefore necessary to add the correction for the attraction of the material which was subtracted in the Bouguer correction and the vertical upward attraction 
caused by hills.

Terrain corrections are usually accomplished by dividing the topography around a station into compartments within which the effect of the topography is computed. Several have designed templates for terrain corrections. Hayford and Bowie (1912), Hammer (1939), and Kane (1962) describe special techniques to approach the problem.

Kane's method utilizes a square template specifically designed to select elevation data from a digital terrain model and use of a digital computer. The system results in a substantial saving of time but the cost factor limits its use to large surveys.

The Hammer method

The Hammer method (Hammer, 1939), which was used to determine the terrain correction in this investigation, utilizes a circular template with radial lines dividing them into compartments, figure 16. The Hammer template is very similar to Hayford-Bowie's (1912).

To get the terrain effect of any particular compartment, the average elevation for that compartment is estimated and the difference between it and the station elevation is derived. Using the table prepared by Hammer (Table 1) the total terrain effect is then obtained for that particular compartment. 


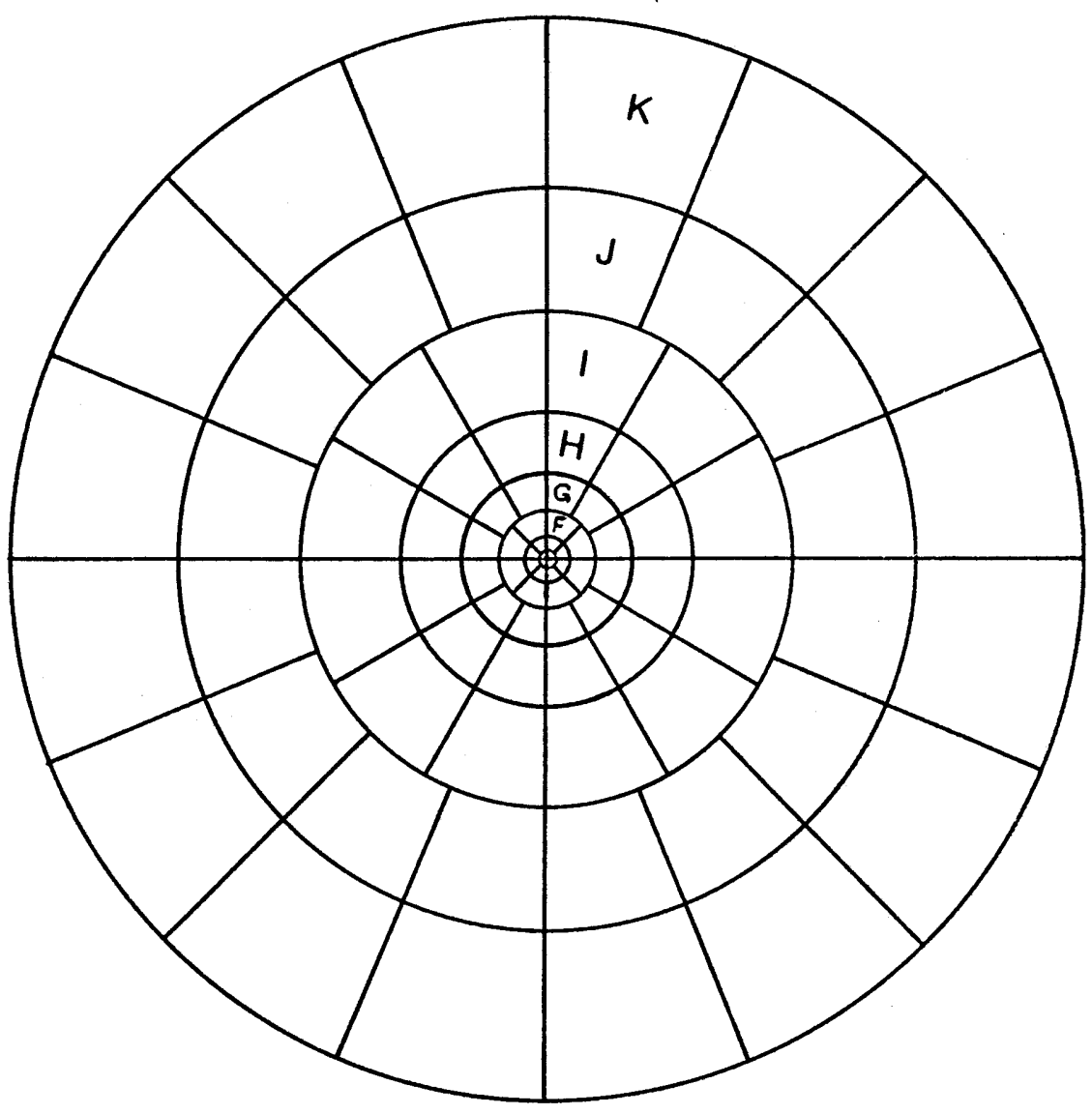

Figure 16. Terrain correction zone chart designed by Hammer (1939). To be used in conjuction with Table 1 for zones B through M. Scale: 1:175,000. 
TABLE I

TERRAIN-CORRECTION TABLE

\begin{tabular}{|c|c|c|c|c|c|c|c|c|c|c|c|}
\hline \multicolumn{2}{|c|}{$\begin{array}{c}\text { Zone B, } \\
4 \text { compartments, } \\
6.56 \text { to } 54.6 \dagger\end{array}$} & \multicolumn{2}{|c|}{$\begin{array}{c}\text { Zone } C, \\
6 \text { compartments, } \\
54.6 \text { to } 175\end{array}$} & \multicolumn{2}{|c|}{$\begin{array}{c}\text { Zone } D \text {, } \\
6 \text { compartments, } \\
175 \text { to } 558\end{array}$} & \multicolumn{2}{|c|}{$\begin{array}{c}\text { Zone } E \text {, } \\
8 \text { compartmonts, } \\
558 \text { to } 1,280\end{array}$} & \multicolumn{2}{|c|}{$\begin{array}{c}\text { Zone } F \text {, } \\
8 \text { compartments, } \\
1,280 \text { to } 2,936\end{array}$} & \multicolumn{2}{|c|}{$\begin{array}{c}\text { Zone } G \text {, } \\
12 \text { compartments, } \\
2,936 \text { to } 5,018\end{array}$} \\
\hline $\pm h, f t$ & $T$ & $\pm h, f t$ & $T$ & $\pm h, f$ & $T$ & $\pm h, f t$ & $T$ & $\pm h, f t$ & $T$ & $\pm h, f t$ & $\boldsymbol{T}$ \\
\hline $0-1.1$ & 0 & $0-4.3$ & 0 & $0-7.7$ & 0 & $0-18$ & 0 & $0-27$ & 0 & $0-\quad 58$ & 0 \\
\hline $\begin{array}{l}1.1-1.9 \\
1.9-2.5 \\
2.5-2.9 \\
2.9-3.4 \\
3.4-3.7\end{array}$ & $\begin{array}{l}0.1 \\
0.2 \\
0.3 \\
0.4 \\
0.5\end{array}$ & $\begin{array}{rr}4.3- & 7.5 \\
7.5- & 9.7 \\
9.7- & 11.5 \\
11.5- & 13.1 \\
13.1- & 14.5\end{array}$ & $\begin{array}{l}0.1 \\
0.2 \\
0.3 \\
0.4 \\
0.5\end{array}$ & $\begin{array}{r}7.7-13.4 \\
13.4-17.3 \\
17.3-20.5 \\
20.5-23.2 \\
23.2-25.7\end{array}$ & $\begin{array}{l}0.1 \\
0.2 \\
0.3 \\
0.4 \\
0.5\end{array}$ & $\begin{array}{l}18-30 \\
30-39 \\
39-47 \\
47-53 \\
53-58\end{array}$ & $\begin{array}{l}0.1 \\
0.2 \\
0.3 \\
0.4 \\
0.5\end{array}$ & $\begin{array}{l}27-46 \\
46-60 \\
60-71 \\
71-80 \\
80-88\end{array}$ & $\begin{array}{l}0.1 \\
0.2 \\
0.3 \\
0.4 \\
0.5\end{array}$ & $\begin{aligned} & 58-100 \\
& 100- 129 \\
& 129- 153 \\
& 153- 173 \\
& 173- 191\end{aligned}$ & $\begin{array}{l}0.1 \\
0.2 \\
0.3 \\
0.4 \\
0.5\end{array}$ \\
\hline $\begin{array}{rr}3.7-7 \\
7 & -9 \\
9 & -12 \\
12 & -14 \\
14 & -16\end{array}$ & $\begin{array}{l}1 \\
2 \\
3 \\
4 \\
5\end{array}$ & $\begin{array}{l}14.5-24 \\
24-32 \\
32-39 \\
39-45 \\
45-51\end{array}$ & $\begin{array}{l}1 \\
2 \\
3 \\
4 \\
5\end{array}$ & $\begin{array}{l}25.7-43 \\
43-56 \\
56-66 \\
66-76 \\
76-84\end{array}$ & $\begin{array}{l}1 \\
2 \\
3 \\
4 \\
5\end{array}$ & $\begin{array}{r}58-97 \\
97-126 \\
126-148 \\
148-170 \\
170-189\end{array}$ & $\begin{array}{l}1 \\
2 \\
3 \\
4 \\
5\end{array}$ & $\begin{array}{r}88-146 \\
146-189 \\
189-224 \\
224-255 \\
255-282\end{array}$ & $\begin{array}{l}1 \\
2 \\
3 \\
4 \\
5\end{array}$ & $\begin{array}{l}191-317 \\
317-410 \\
410-486 \\
486-552 \\
552-611\end{array}$ & $\begin{array}{l}1 \\
2 \\
3 \\
4 \\
5\end{array}$ \\
\hline $\begin{array}{ll}16 & -19 \\
19 & -21 \\
21 & -24 \\
24 & -27 \\
27 & -30\end{array}$ & $\begin{array}{r}6 \\
7 \\
8 \\
9 \\
10\end{array}$ & $\begin{array}{l}51-57 \\
57-63 \\
63-68 \\
68-74 \\
74-80\end{array}$ & $\begin{array}{r}6 \\
7 \\
8 \\
9 \\
10\end{array}$ & $\begin{array}{rr}84 & -92 \\
92 & -100 \\
100 & -107 \\
107 & -114 \\
114 & -120\end{array}$ & $\begin{array}{r}6 \\
7 \\
8 \\
9 \\
10\end{array}$ & $\begin{array}{l}189-206 \\
206-222 \\
222-238 \\
238-252 \\
252-266\end{array}$ & $\begin{array}{r}6 \\
7 \\
8 \\
9 \\
10\end{array}$ & $\begin{array}{l}282-308 \\
308-331 \\
331-353 \\
353-374 \\
374-394\end{array}$ & $\begin{array}{r}6 \\
7 \\
8 \\
9 \\
10\end{array}$ & $\begin{array}{l}611-666 \\
666-716 \\
716-764 \\
764-809 \\
809-852\end{array}$ & $\begin{array}{r}6 \\
7 \\
8 \\
9 \\
10\end{array}$ \\
\hline $27-30$ & & $\begin{array}{rr}80 & -86 \\
86 & -91 \\
91 & -97 \\
97 & -104 \\
104 & -110\end{array}$ & $\begin{array}{l}11 \\
12 \\
13 \\
14 \\
15\end{array}$ & $\begin{array}{ll}120 & -127 \\
127 & -133 \\
133 & -140 \\
140 & -146 \\
146 & -152\end{array}$ & $\begin{array}{l}11 \\
12 \\
13 \\
14 \\
15\end{array}$ & $\begin{array}{l}266-280 \\
280-293 \\
293-306 \\
306-318 \\
318-331\end{array}$ & $\begin{array}{l}11 \\
12 \\
13 \\
14 \\
15\end{array}$ & $\begin{array}{l}394-413 \\
413-431 \\
431-449 \\
449-466 \\
466-483\end{array}$ & $\begin{array}{l}11 \\
12 \\
13 \\
14 \\
15\end{array}$ & $\begin{array}{r}852-894 \\
894-933 \\
933-972 \\
972-1,009 \\
1,009-1,046\end{array}$ & $\begin{array}{l}11 \\
12 \\
13 \\
14 \\
15\end{array}$ \\
\hline \multicolumn{2}{|c|}{$\begin{array}{c}\text { Zone } H, \\
12 \text { compartments, } \\
5,018 \text { to } 8,578\end{array}$} & \multicolumn{2}{|c|}{$\begin{array}{c}\text { Zone I, } \\
12 \text { compartments, } \\
8,578 \text { to } 14,662\end{array}$} & \multicolumn{2}{|c|}{$\begin{array}{l}\text { Zone J, } \\
16 \text { compartments, } \\
14,662 \text { to } 21,826\end{array}$} & \multicolumn{2}{|c|}{$\begin{array}{c}\text { Zone } K \text {, } \\
16 \text { compartments, } \\
21,826 \text { to } 32,490\end{array}$} & \multicolumn{2}{|c|}{$\begin{array}{c}\text { Zone } L \text {, } \\
16 \text { compartments, } \\
32,490 \text { to } 48,365\end{array}$} & \multicolumn{2}{|c|}{$\begin{array}{l}\text { Zone } M \text {, } \\
16 \text { compartments } \\
48,365 \text { to } 71,996\end{array}$} \\
\hline$\pm \boldsymbol{h}, \mathbf{f t}$ & $\boldsymbol{T}$ & $\pm h, f t$ & $T$ & $\pm h, f t$ & $\boldsymbol{T}$ & $\pm h, f t$ & $T$ & $\pm h, \mathbf{f t}$ & $T$ & $\pm h, f t$ & $\mathbf{T}$ \\
\hline $0-\quad 75$ & 0 & $0-99$ & 0 & $0-167$ & 0 & $0-204$ & 0 & $0-249$ & 0 & $0-304$ & 0 \\
\hline $\begin{array}{cc}75- & 131 \\
131- & 169 \\
169- & 200 \\
200- & 226 \\
226- & 250\end{array}$ & $\begin{array}{l}0.1 \\
0.2 \\
0.3 \\
0.4 \\
0.5\end{array}$ & $\begin{array}{r}99-171 \\
171-220 \\
220-261 \\
261-296 \\
296-327\end{array}$ & $\begin{array}{l}0.1 \\
0.2 \\
0.3 \\
0.4 \\
0.5\end{array}$ & $\begin{array}{ll}167- & 290 \\
290- & 374 \\
374- & 443 \\
443- & 502 \\
502- & 555\end{array}$ & $\begin{array}{l}0.1 \\
0.2 \\
0.3 \\
0.4 \\
0.5\end{array}$ & $\begin{array}{l}204-354 \\
354-457 \\
457-540 \\
540-613 \\
613-677\end{array}$ & $\begin{array}{l}0.1 \\
0.2 \\
0.3 \\
0.4 \\
0.5\end{array}$ & $\begin{array}{l}249-431 \\
431-557 \\
557-659 \\
659-747 \\
747-826\end{array}$ & $\begin{array}{l}0.1 \\
0.2 \\
0.3 \\
0.4 \\
0.5\end{array}$ & $\begin{array}{l}304-526 \\
526-680 \\
680-804 \\
804-912 \\
912-1,008\end{array}$ & $\begin{array}{l}0.1 \\
0.2 \\
0.3 \\
0.4 \\
0.5\end{array}$ \\
\hline $\begin{array}{l}250-414 \\
414-535 \\
535-633 \\
633-719 \\
719-796\end{array}$ & $\begin{array}{l}1 \\
2 \\
3 \\
4 \\
5\end{array}$ & $\begin{array}{l}327-540 \\
540-698 \\
698-827 \\
827-938 \\
938-1,038\end{array}$ & $\begin{array}{l}1 \\
2 \\
3 \\
4 \\
5\end{array}$ & $\begin{array}{r}555-918 \\
918-1,185 \\
1,185-1,403 \\
1,403-1,592 \\
1,592-1,762\end{array}$ & $\begin{array}{l}1 \\
2 \\
3 \\
4 \\
5\end{array}$ & $\begin{array}{r}677-1,119 \\
1,119-1,445 \\
1,445-1,711 \\
1,711-1,941 \\
1,941-2,146\end{array}$ & $\begin{array}{l}1 \\
2 \\
3 \\
4 \\
5\end{array}$ & $\begin{array}{r}826-1,365 \\
1,365-1,763 \\
1,763-2,086 \\
2,086-2,366 \\
2,366-2,617\end{array}$ & $\begin{array}{l}1 \\
2 \\
3 \\
4 \\
5\end{array}$ & $\begin{array}{l}1,008-1,665 \\
1,665-2,150 \\
2,150-2,545 \\
2,545-2,886 \\
2,886-3,191\end{array}$ & $\begin{array}{l}1 \\
2 \\
3 \\
4 \\
5\end{array}$ \\
\hline $\begin{array}{r}796-866 \\
866-931 \\
931-992 \\
992-1,050 \\
1,050-1,105\end{array}$ & $\begin{array}{r}6 \\
7 \\
8 \\
9 \\
10\end{array}$ & $\begin{array}{l}1,038-1,129 \\
1,129-1,213 \\
1,213-1,292 \\
1,292-1,367 \\
1,367-1,438\end{array}$ & $\begin{array}{r}6 \\
7 \\
8 \\
9 \\
10\end{array}$ & $\begin{array}{l}1,762-1,917 \\
1,917-2,060 \\
2,060-2,195 \\
2,195-2,322 \\
2,322-2,443\end{array}$ & $\begin{array}{r}6 \\
7 \\
8 \\
9 \\
10\end{array}$ & $\begin{array}{l}2,146-2,335 \\
2,335-2,509 \\
2,509-2,672 \\
2,672-2,826 \\
2,826-2,973\end{array}$ & $\begin{array}{r}6 \\
7 \\
8 \\
9 \\
10\end{array}$ & $\begin{array}{l}2,617-2,846 \\
2,846-3,058 \\
3,058-3,257 \\
3,257-3,444 \\
3,444-3,622\end{array}$ & $\begin{array}{r}6 \\
7 \\
8 \\
9 \\
10\end{array}$ & $\begin{array}{l}3,191-3,470 \\
3,470-3,728 \\
3,728-3,970 \\
3,970-4,198 \\
4,198-4,414\end{array}$ & $\begin{array}{r}6 \\
7 \\
8 \\
9 \\
10\end{array}$ \\
\hline $\begin{array}{r}1,105-1,158 \\
1,158-1,209 \\
1,209-1,257 \\
1,257-1,305 \\
1,305-1,350\end{array}$ & $\begin{array}{l}11 \\
12 \\
13 \\
14 \\
15\end{array}$ & $\begin{array}{l}1,438-1,506 \\
1,506-1,571 \\
1,571-1,634 \\
1,634-1,694 \\
1,694-1,753\end{array}$ & $\begin{array}{l}11 \\
12 \\
13 \\
14 \\
15\end{array}$ & $\begin{array}{l}2,443-2,558 \\
2,558-2,669 \\
2,669-2,776 \\
2,776-2,879 \\
2,879-2,978\end{array}$ & $\begin{array}{l}11 \\
12 \\
13 \\
14 \\
15\end{array}$ & & & & & & \\
\hline
\end{tabular}

Table 1 is to be used in conjuction with figure 16. Note: Prepared by Hammer (1939) and used with permission of McGraw-Hill Book Company. From Geophysical Prospecting by Dobrin (1960). 


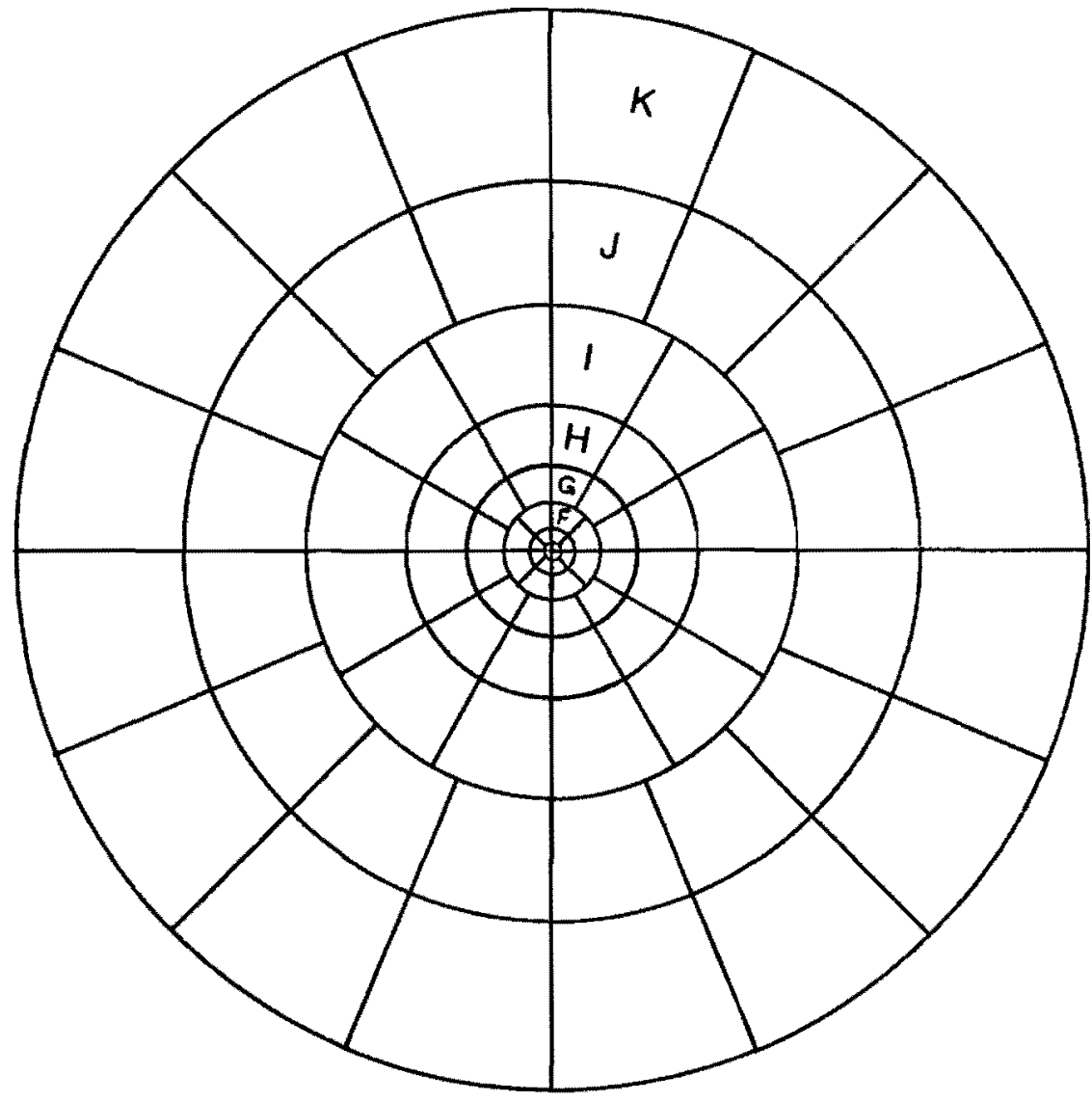

Figure 16. Terrain correction zone chart designed by Hammer (1939), To be used in conjuction with Table 1 for zones B through M. Scale: 1:175,000. 
The density used by Hammer in deriving the table was 2. 0 . It becomes necessary, in most cases, to correct the total terrain correction for a given station by multiplying the total by a factor of $\sigma / 2, \sigma$ being the density selected. The table gives the terrain correction in units of $1 / 100$ milligals and has a precision of about 0.1 milligals per station, dependent upon the accuracy of the maps used.

The table was computed from the formula for the gravitational attraction of a cylinder (Hammer, 1939) which corresponds to one zone or ring on the terrain correction template.

\section{Drift Correction}

Nettleton's closed loop traverse method, as was previously mentioned, was followed in making all instrument readings, Nettleton (1940). The base stations were established close enough to the line of each traverse so that it could be reoccupied within one or two hours. Gravity stations were occupied consecutively as schematically outlined in figure 17.

Ideally, the drift corrected values are those that would be observed if all the stations were simultaneously occupied at the time the first reading was made. The drift corrected values are the scaled differences between the reoccupied base stations values. The Worden gravity meter used in this study had a good closure resulting in a minimal drift error. An example of a drift curve for the 


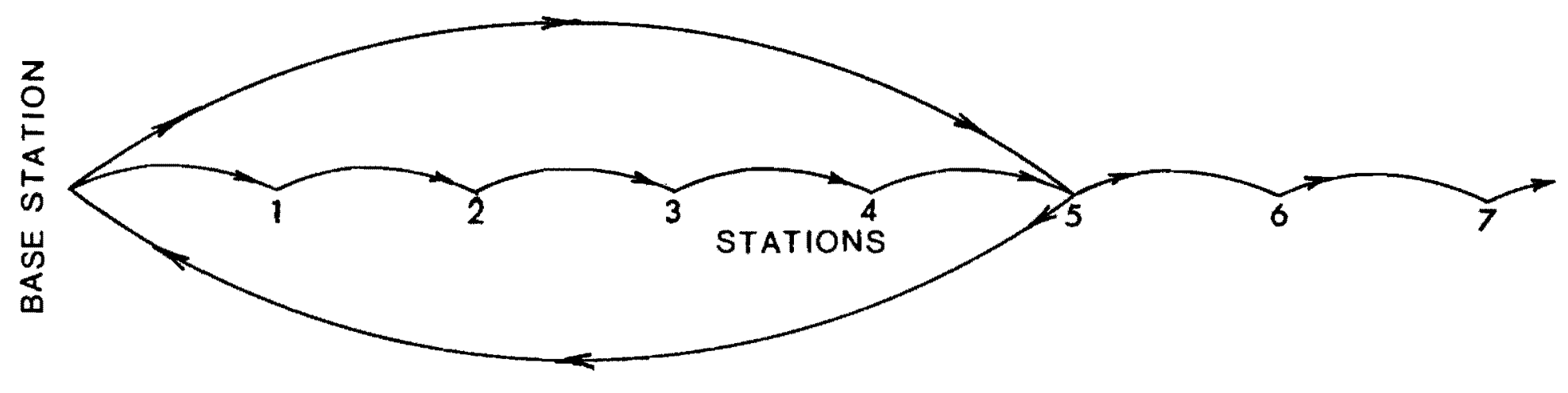

Figure 17. Schematic outline of closed loop traverse method. 
Worden gravity meter is seen in figure 18.

Each base station was then tied to the absolute gravity stations described in figure 3. This procedure followed the loop method but only involved the base stations. The individual gravity stations were then rescaled to the differences found between the reoccupancy of the absolute gravity station at the Portland International Airport.

\section{Accuracy of Reductions}

Gravity reductions are subjected to numerous sources of error. Discussed are the more important sources of error with an estimation of the probable maximum error per station.

Instrument reading

The instrument sensitivity, which is the product of the instrument constant $(0.1037)$ and the smallest unit of scale on the gravity meter (0.1), determines the maximum source of error.

\section{$\underline{\text { Eree-air correction }}$}

The correction factor of 0.09406 milligals per foot results in a correction of nearly 0.1 milligals per foot of elevation error. It is for this reason that elevations must be determined as accurately as possible. The final station correction is dependent upon the accuracy of the maps used if surveying techniques are not employed. This survey has a control accuracy of \pm 5 feet, \pm 10 feet on steep 


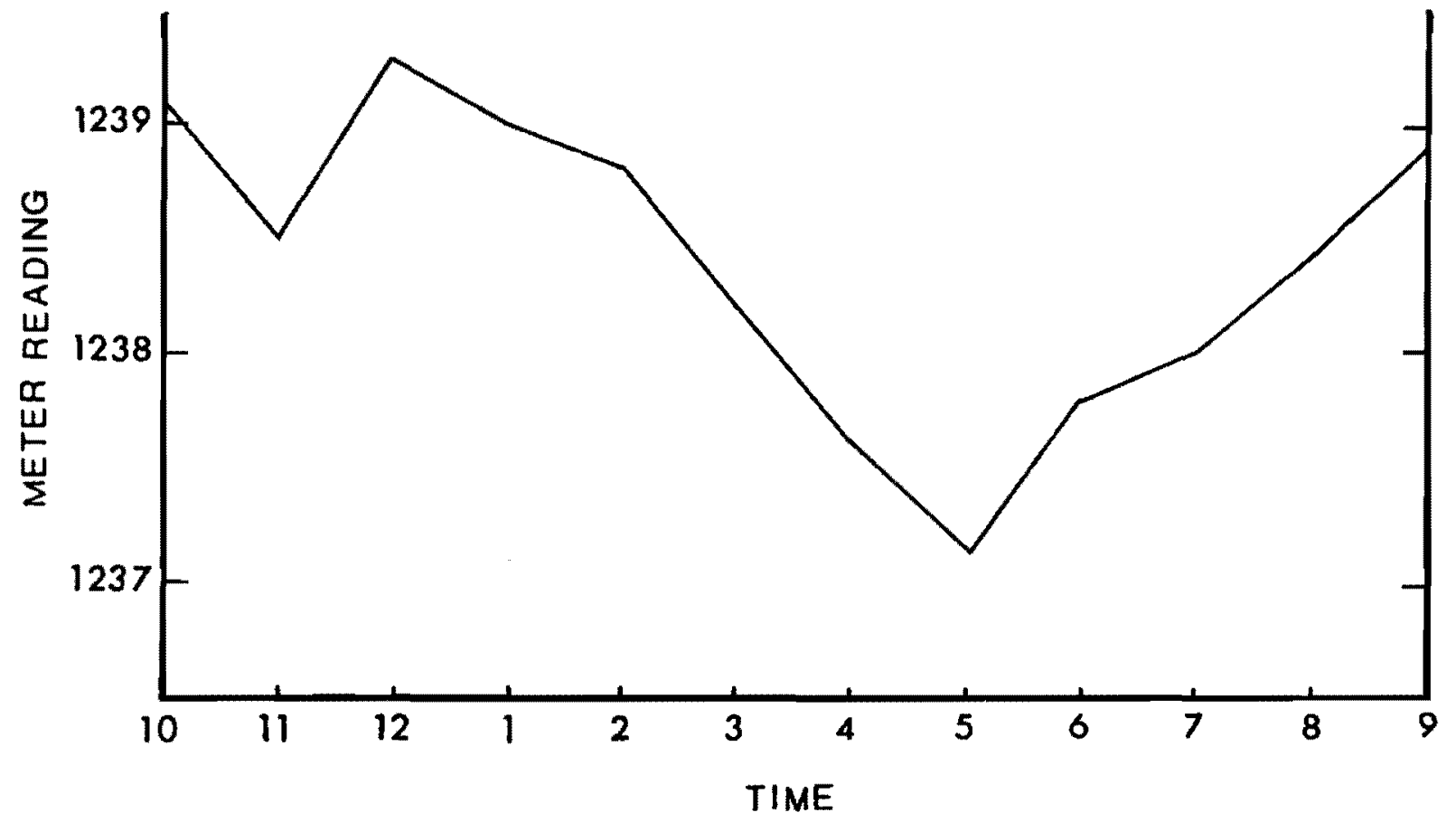

Figure 18. Drift curve for February 2, 1971. 
slopes, which gives a maximum error of nearly 1.0 milligal $(0.1$ milligal per foot). In this survey, the maximum error only applies to 21 of the 166 gravity stations.

\section{Bouguer correction}

The Bouguer correction of $0.01276 \sigma \mathrm{h}$ milligals, where $\mathrm{h}$ is the thickness of the Bouguer slab, produced a maximum error of 0.034 milligals per foot at a density of $2.67 \mathrm{gm} / \mathrm{cc}$. The total elevation correction (free-air minus Bouguer) results in a maximum gravity change of 0.66 milligals per foot of elevation at a density of 2.67 $\mathrm{gm} / \mathrm{cc}$.

Selection of surface densities can give rise to a large error in gravity reductions. An uncertainty of $0.1 \mathrm{gm} / \mathrm{cc}$ results in a $0.001 \mathrm{~h}$ milligal error, where $h$ is in feet. In choosing a uniform density, the resultant anomly represents the total vertical attraction of the contrasted body below the gravity station.

\section{Latitude correction}

The stations were individually corrected. The accuracy of the correction is then determined by the accuracy of the latitude measurement. A one second error in latitude produces an approximate error of 0.02 milligals. 


\section{Terrain correction}

The terrain correction value is no more accurate than the elevation estimations, which are dependent on the contour interval of the topographic map used. These errors may vary from a significant amount close to the station to a negligible amount several miles from the station depending upon topography. A precision of about 0.1 milligals or better has been designed into Hammer's template and table. Elevation estimations are nearly negligible where topography is relatively flat, especially near the station. In the investigated area, accuracy is high and error is considered insignificant, except for those 21 stations located on steep slopes.

An inherent error is provided by the assemed density. This error is of the same magnitude as that found in the Bouguer correction. Considering the error in elevation estimation and the inherent density error, it is estimated that the total maximum error is less than 0.5 milligals per station.

\section{Drift correction}

During the course of a day the gravity meter will vary in the observed readings. The drift is due to the total effect of temperature changes, tidal effect, and the stretching of the internal operating components. The instrument used was self-compensating for ambient temperature changes which only leaves earth tides and the 
instrument drift to be corrected for.

Heiland (in Dobrin, 1960) gives a formula for calculating the tidal effect. The maximum effect of a complete tidal cycle is 0,3 milligals (Dobrin, 1960). This tedious calculation may be circumvented by applying the loop method. Base station reoccupancy was within two hours, giving a maximum error of less than 0.05 milligals.

Probable maximum error

The total maximum estimated error per gravity station is:

\begin{tabular}{ll} 
instrument reading & 0.01 \\
elevation correction & 0.66 \\
latitude correction & 0.02 \\
terrain correction & 0.50 \\
drift correction & $\underline{0.05}$ \\
\hline
\end{tabular}

total

1.24 milligals

This maximum error per gravity station would only apply if all of the errors applied were in the same direction. It is, therefore, believed that an average maximum error is less than 1.0 milligal.

\section{The Bouguer Anomaly}

The Bouguer anomaly is defined by Dobrin (1960) as

"Observed grav. + free-air corr. - Bouguer corr. + topographic corr. - theoretical grav."

The observed gravity, g, as defined by Heinrichs (personal communication), is the "value of $g$ at base station \pm difference in meter reading at station and base station times meter constant." The other 
corrections have been previously defined.

If the density of the material found below sea level is everywhere equal, the Bouguer anomaly is expected to be zero. A departure from zero represents a relative variation of the densities below sea level. The anomaly, however, may also reflect the selection of the density by showing a contrast above sea level.

One station in the gravity survey has a known absolute value so all other relative gravity observations were changed from the relative to an absolute value by comparison. This value was used as the value of $g$ in the defined observed gravity.

Appendix IV lists the absolute gravity under the observed gravity column and all other correction values for each gravity station. The absolute gravity is the non-corrected value at the station. All of the Bouguer anomalies are negative in the Portland area. The zero Bouguer contour line in Oregon appears on the west edge of the Willamette Valley. The Coast Range has positive Bouguer anomalies (figure 10, Berg and Thiruvathukal, 1967b). 
APPENDIX IV

GRAVITY CORRECTION TABLES

\section{Key to Correction Tables}

\section{COLUMN}

1 Station Number

2 Elevation (in feet)

3 Meter Reading

4 Meter Reading times meter constant (0.1037)

5 Observed Gravity*

6 Free-air Correction (0.09406h)

7 Bouguer Correction (0.03407h)

8 Terrain Correction

9 Theoretical Gravity

10 Degree of Latitude

11 Free-air Anomaly

12 Bouguer Anomaly

* Observed Gravity value obtained by the following steps:

(1) Take meter reading at an absolute gravity station (Portland International Airport, 1643.0).

(2) Multiply meter reading by meter constant $(0.1037)=170.379)$.

(3) Find \pm difference between step 2 and value in column 4 from the correction tables.

(4) Add or subtract difference from known gravity value at Portland International $A$ ir port, 980648.24 milligals. 


\section{MILWAUKIE TRAVERSE}
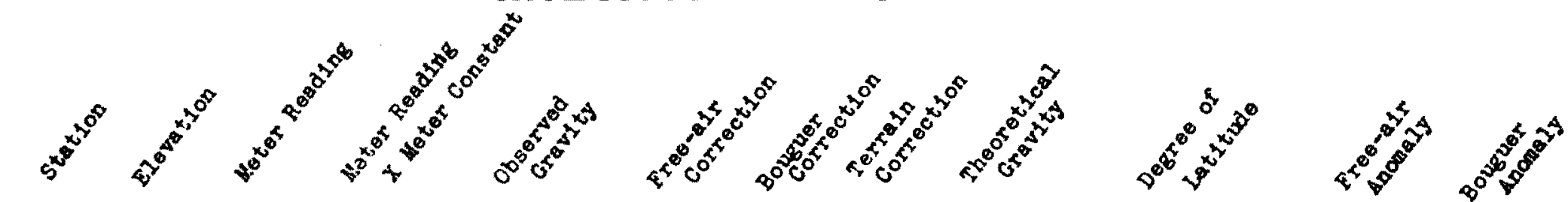

$\begin{array}{crrr}\text { BASE } & 121 & 1591.1 & 164.997 \\ 1 & 153 & 1577.8 & 163.618 \\ 2 & 115 & 1611.3 & 167.092 \\ 3 & 83 & 1649.6 & 171.064 \\ 4 & 37 & 1675.9 & 173.791 \\ 5 & 44 & 1675.1 & 173.708 \\ 6 & 76 & 1656.3 & 171.758 \\ 7 & 107 & 1633.7 & 169.415 \\ 8 & 146 & 1612.5 & 167.216 \\ 9 & 165 & 1608.3 & 166.781\end{array}$

980542.86 980641.48

$11.38 \quad 4.12$

.134

980671.84

14.39

$5.21 \quad .164$

980668.98

$45^{\circ} 28^{\prime} 10.0^{\prime \prime}$ 980644.95
980648.92

7.81

3.92 .187

980668.86

$45^{\circ} 26^{\prime} 16.0^{\prime \prime}$

$-17.60$

$-21.59$

980651.65

$1.83 \quad .206$

980668.75

$45^{\circ} 26^{\prime} 11.5^{\prime \prime}$

$-13.11$

$-18.16$

980651.57

1.50

468.63

45026.02 .00

$-12.02$

$-16.82$

$\begin{array}{llll}4.14 & 1.50 & .399\end{array}$

(45026.00.0"

980649.61

2.59

980668.54

$\begin{array}{lll}10.06 & 3.65 \quad .322\end{array}$

$980668.4845^{\circ} 25^{\circ} 56.0^{\circ}$

$-13.00$

$-14.64$

980647.28

13.73

4.97

.294

980668.4145025 '53.5"

980644.64

$\begin{array}{lll}15.52 & 5.62 & .259\end{array}$

$980668.3145^{\circ} 25^{\circ} 49.5^{\prime \prime}$

$-11.78-14.01$

$-11.14-14.47$

$-9.60-14.28$

$-8.15-13.52$

\section{GLADSTONE TRAVERSE}

$\begin{array}{crrrr}\text { BASE } & 113 & 1528.8 & 153.537 & 980636.40 \\ 1 & 111 & 1515.3 & 157.137 & 980635.00 \\ 2 & 108 & 1517.1 & 157.323 & 980635.18 \\ 3 & 105 & 1518.6 & 157.479 & 980635.35 \\ 4 & 102 & 1516.5 & 157.261 & 980635.12 \\ 5 & 101 & 1530.3 & 158.692 & 980636.55 \\ 6 & 96 & 1525.4 & 158.184 & 980636.04 \\ 7 & 95 & 1528.0 & 158.453 & 980636.31 \\ 8 & 106 & 1520.7 & 157.697 & 980635.56 \\ 9 & 115 & 1534.5 & 159.128 & 980635.81 \\ 10 & 113 & 1534.5 & 159.128 & 980636.99 \\ 11 & 109 & 1546.7 & 160.393 & 980638.25 \\ 12 & 108 & 1556.4 & 161.399 & 980639.26 \\ 13 & 129 & 1551.4 & 160.880 & 980638.74 \\ 14 & 144 & 1558.4 & 161.606 & 980639.47 \\ 15 & 160 & 1557.8 & 161.544 & 980639.40 \\ 16 & 176 & 1548.7 & 160.600 & 980638.46 \\ 17 & 195 & 1542.4 & 159.947 & 980637.81 \\ 18 & 194 & 1541.4 & 159.843 & 980637.70\end{array}$

$\begin{array}{rrr}10.59 & 3.84 & .219 \\ 10.44 & 3.78 & .164 \\ 10.16 & 3.68 & .144 \\ 9.88 & 3.58 & .159 \\ 9.59 & 3.48 & .138 \\ 9.50 & 3.44 & .124 \\ 9.03 & 3.27 & .178 \\ 8.94 & 3.24 & .174 \\ 9.97 & 3.61 & .212 \\ 10.82 & 3.92 & .164 \\ 10.63 & 3.85 & .152 \\ 10.25 & 3.71 & .179 \\ 10.16 & 3.68 & .158 \\ 12.13 & 4.40 & .198 \\ 13.54 & 4.91 & .232 \\ 15.05 & 5.45 & .198 \\ 16.56 & 6.00 & .215 \\ 18.34 & 6.64 & .184 \\ 18.25 & 6.61 & .179\end{array}$

$980666.5645^{\circ} 24^{\prime} 39.5^{\prime \prime}$ $980666.2145^{\circ} 24 \cdot 25.5^{\prime \prime}$ $980666.10450^{\circ} 4.17 .0 "$ $980665.8945^{\circ} 24 \cdot 13.0^{\prime \prime}$ $980665.8045^{\circ} 24^{\prime} 09.5^{\prime \prime}$ $980665.6745^{\circ} 24^{\prime} 04.0^{\prime \prime}$ $980665.6045^{\circ} 24^{\prime} 01.5^{\prime \prime}$ $930665.5045^{\circ} 23 \cdot 57.5^{\prime \prime}$ $980665.4245023^{\prime} 54.0 "$ $980665.3345^{\circ} 23^{\prime} 50.5^{\prime \prime}$ $980665.1945^{\circ} 23 \cdot 45.0^{n}$ $980665.1245^{\circ} 23^{\prime} 42.0 "$ $980665.0245023 \cdot 38.0^{\prime \prime}$ $980664.9345^{\circ} 23^{\prime} 34.5^{\prime \prime}$ $980664.8245^{\circ} 23 \cdot 30.0^{\prime \prime}$ $980664.7745023 \cdot 28.0 "$ $980664.7345^{\circ} 23^{\prime} 26.5^{\prime \prime}$ $980664.6745^{\circ} 23^{\prime} 24.0^{\prime \prime}$ 


\section{REDLAND TRAVERSE}

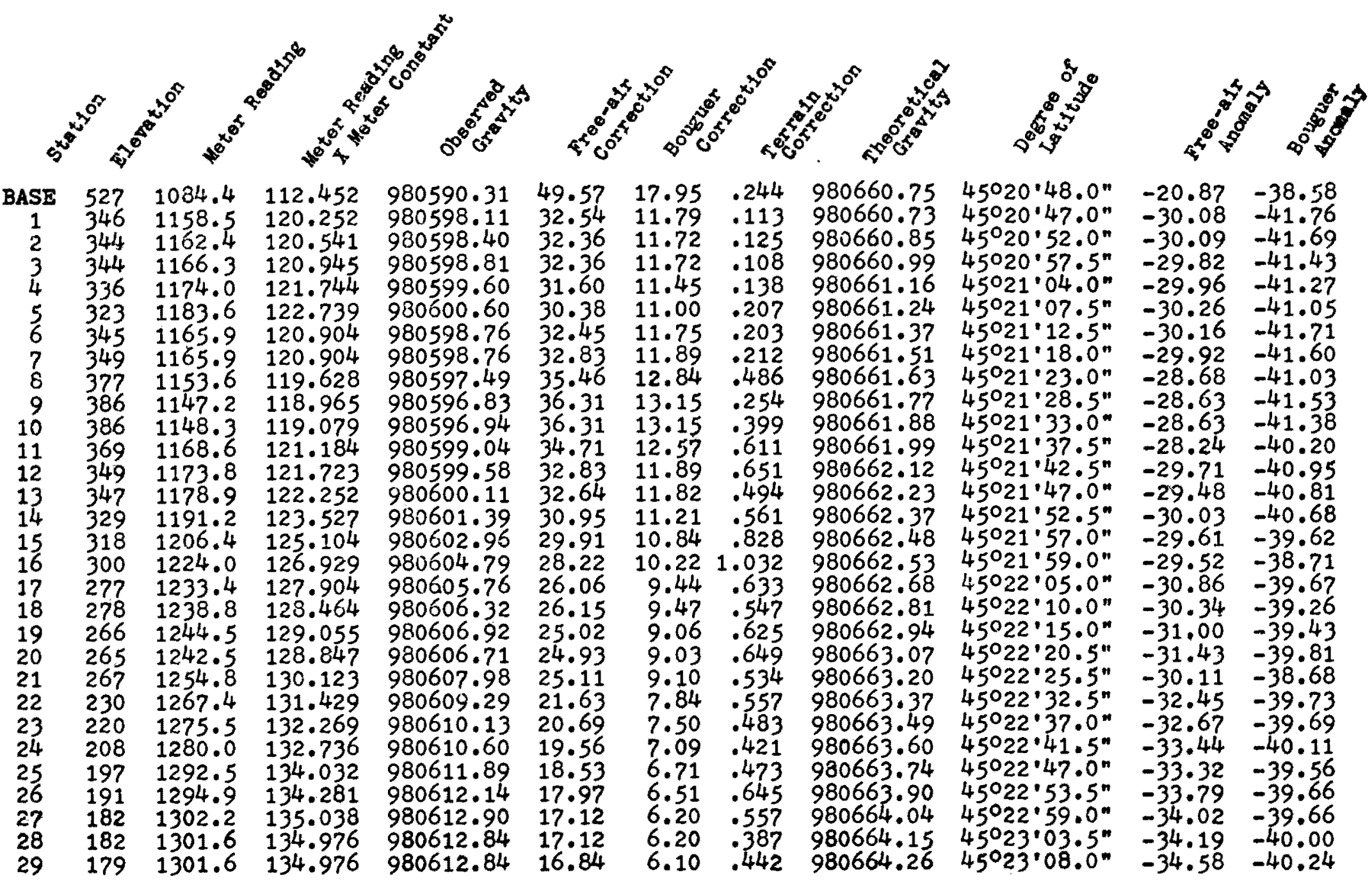


TRANSMISSION LINE TRAVERSE

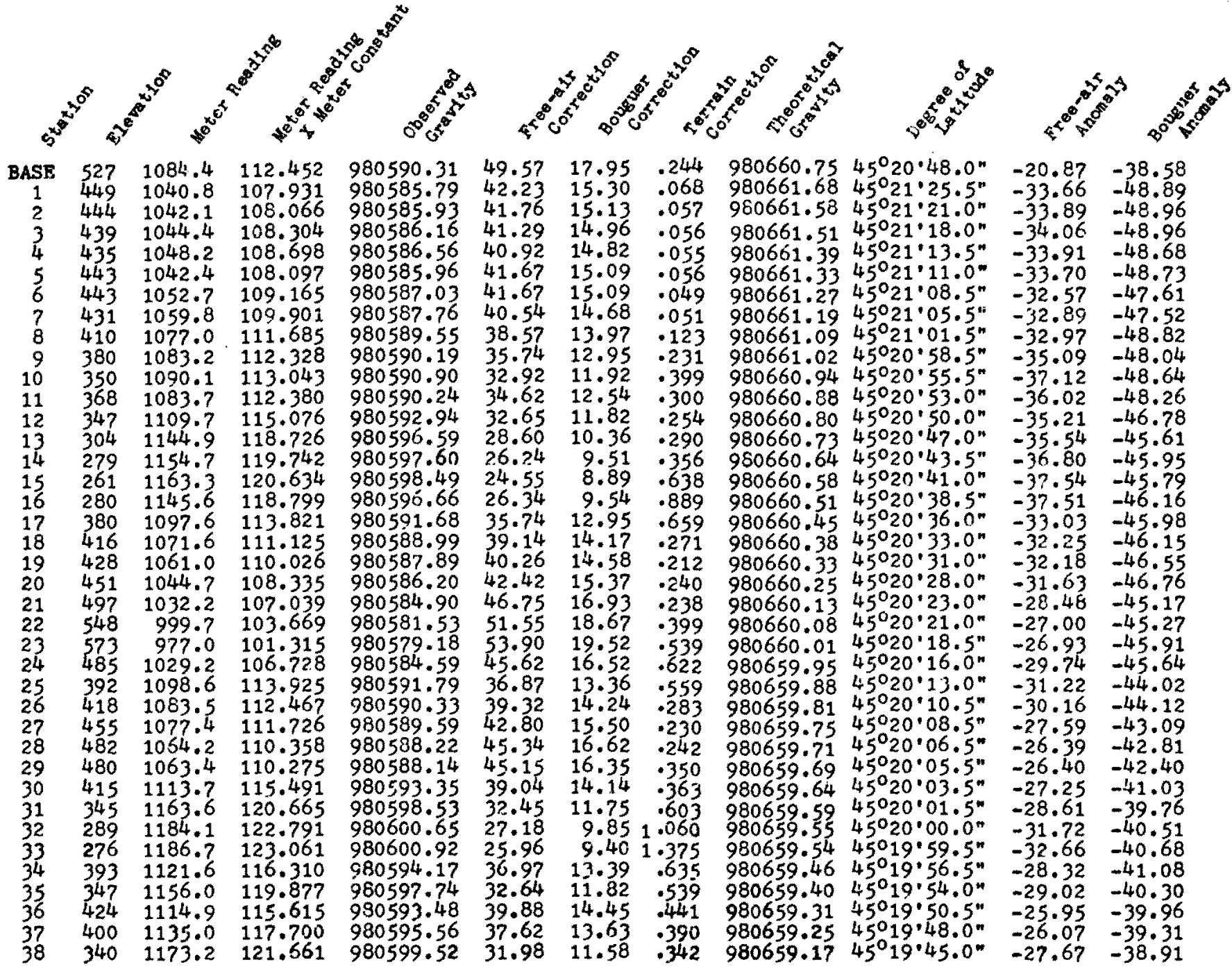


PARADISE PARK TRAVERSE

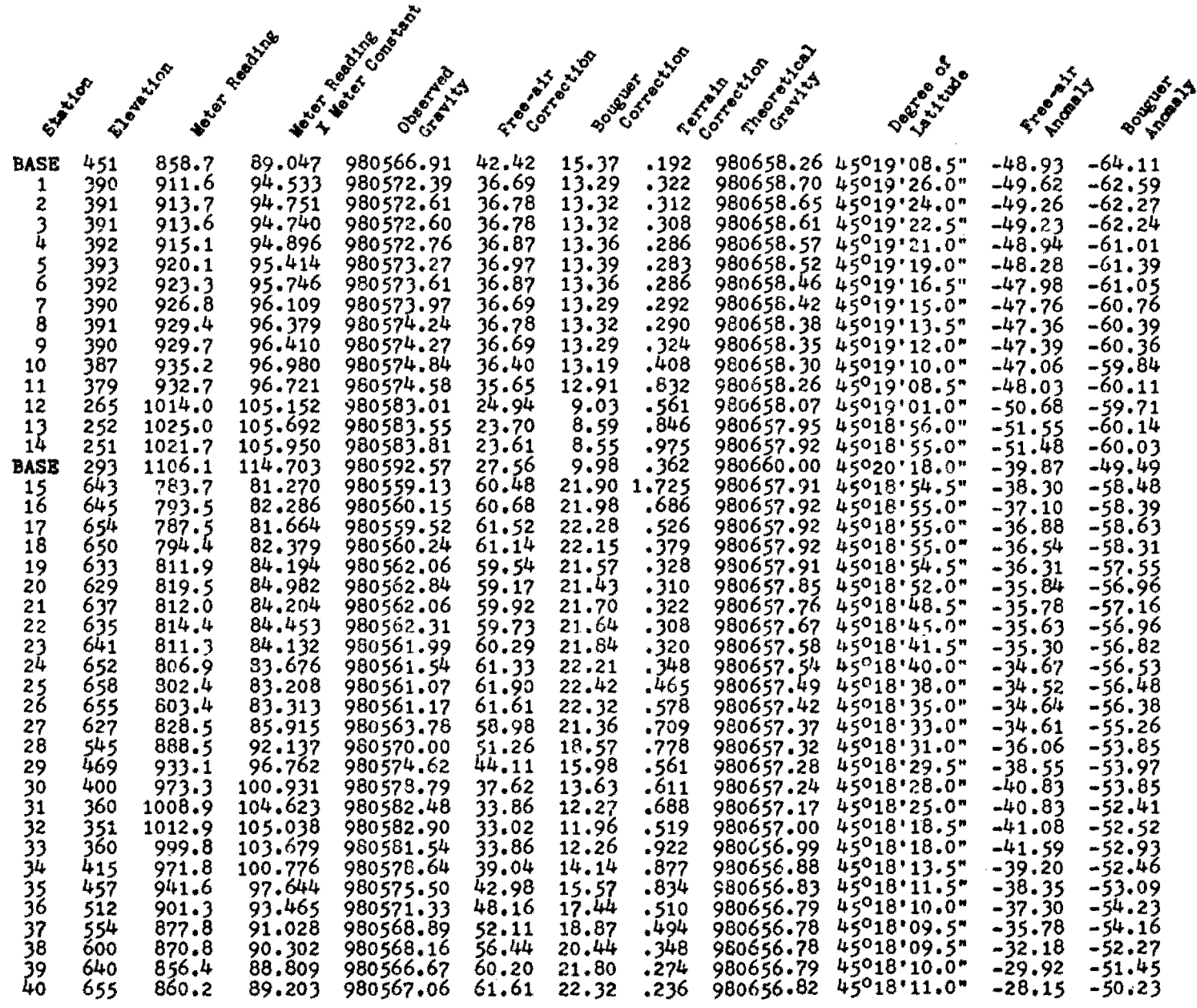




\section{ESTACADA TRAVERSE}

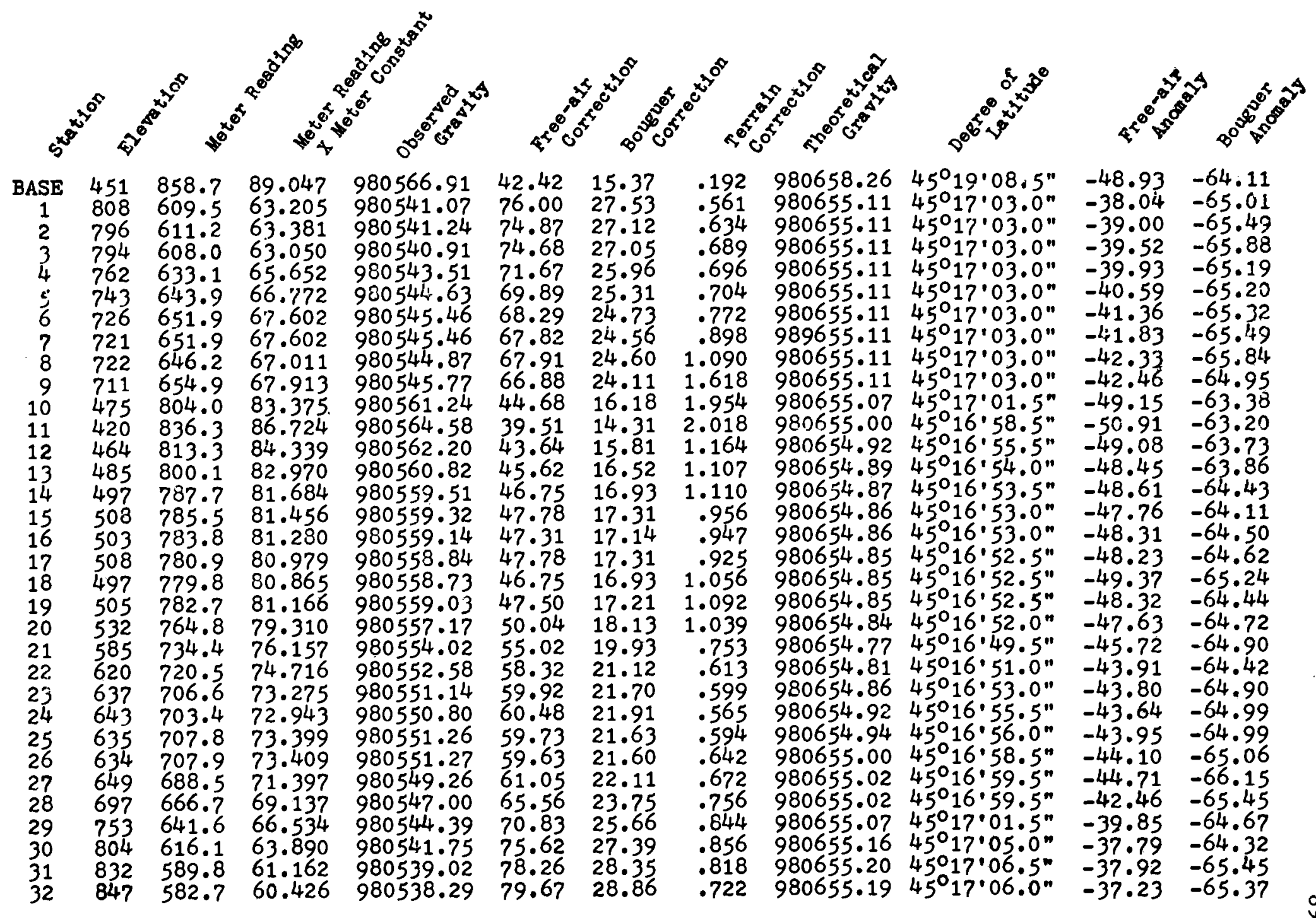




\section{APPENDIX V}

MAGNETIC DATA

Station

1

2

3

4

5

6

7

8

9

10

11

12

13

14

15

16

17

18

-32
-44
-265
+172
+107
+102
+105
+95
+36
+54
-18
+155
+155
+115
+30
+43
+49
+45

$1 \mathrm{~K}$

$1 \mathrm{~K}$

300

300

300

300

300

300

100

100

100

300

300

300

$1 \mathrm{~K}$

$1 \mathrm{~K}$

$1 \mathrm{~K}$

$1 \mathrm{~K}$

Total

Gammas

Fischers Mill-M Traverse

$-145$

$-165$

$-280$

$-50$

$-62$

$-78$

$-62$

$-72$
300

300

300

$1 \mathrm{~K}$

$1 \mathrm{~K}$

$1 \mathrm{~K}$

$1 \mathrm{~K}$

$1 \mathrm{~K}$
$-320$

$-440$

$-265$

$+172$

$+107$

$+102$

$+105$

$+95$

$+36$

$+54$

$-18$

$+155$

$+155$

$+115$

$+300$

$+430$

$+490$

$+450$

8

$-145$

$-165$

$-280$

$-500$

$-620$

$-780$

$-620$

$-720$ 


$\begin{array}{cccc}\text { Station } & \begin{array}{c}\text { Instrument } \\ \text { Reading }\end{array} & \begin{array}{c}\text { Meter } \\ \text { Scale }\end{array} & \begin{array}{c}\text { Total } \\ \text { Gammas }\end{array} \\ 9 & -72 & 1 \mathrm{~K} & -720 \\ 10 & -48 & 1 \mathrm{~K} & -480 \\ 11 & -52 & 1 \mathrm{~K} & -520 \\ 12 & -41 & 1 \mathrm{~K} & -410 \\ 13 & -43 & 1 \mathrm{~K} & -430 \\ 14 & -39 & 1 \mathrm{~K} & -390\end{array}$

Estacada-M Traverse

$\begin{array}{llll}1 & -194 & 300 & -194 \\ 2 & -51 & 1 \mathrm{~K} & -510 \\ 3 & -160 & 300 & -160 \\ 4 & -135 & 300 & -135 \\ 5 & +52 & 1 \mathrm{~K} & +520 \\ 6 & -33 & 300 & -33 \\ 7 & +14 & 300 & +14 \\ 8 & -15 & 100 & -15 \\ 9 & -100 & 3 \mathrm{~K} & -1000 \\ 10 & +176 & 3 \mathrm{~K} & +1760 \\ 11 & -94 & 1 \mathrm{~K} & -940 \\ 12 & -82 & 3 \mathrm{~K} & -820 \\ 13 & -30 & 1 \mathrm{~K} & -300 \\ 14 & -56 & 10 \mathrm{~K} & -5600 \\ 15 & -100 & 3 \mathrm{~K} & -1000 \\ 16 & -115 & 3 \mathrm{~K} & -1150 \\ 17 & -107 & 3 \mathrm{~K} & -1070\end{array}$




\section{APPENDIX VI}

\section{WELI LOGS}

The wells discussed in this report follow the numbering designation according to the Federal rectangular system of land division. In the City of Gladstone well (2/2-20F1), for example, the part preceeding the hyphen represents the township and range (T. 2 S., R. 2 E.) south and east of the Willamette base line and meridian. The letters " $S$ " and " $E$ " have been omitted for wells lying south of the base line and east of the meridian. The number following the hyphen indicates the section (section 20), see figure $26 \mathrm{~A}$ and $\mathrm{B}$, the letter refer $\mathrm{B}$ to the 40 -acre tract in the section $(F)$, and the final number indicates the number of the well within the 40 acre tract. Thus, the City of Gladstone well (2/2-20F1) lies in the SEl/4NW $1 / 4$ sec. 20, T. 2 S., R. 2 E., and is the first well listed in the tract.

The state of Oregon now designates the location of the wells by a new lettering system, figure $25 \mathrm{C}$. For example, (2/2-20bdl) indicates the first well located in the SEl/4NWl/4 sec. $20, T .2 \mathrm{~S}$. , R. 2 E. A well designated by (2/2-20bdc) would indicate a well located in the SW1/4SEl/4NW 1/4 sec. 20, T. 2 S., R. 2 E. 
R. 2 E.

\begin{tabular}{|c|c|c|c|c|c|}
\hline 6 & 5 & 4 & 3 & 2 & 1 \\
\hline 7 & 8 & 9 & 10 & 11 & 12 \\
\hline 18 & 17 & 16 & 15 & 14 & 13 \\
\hline 19 & 20 & 22 & 22 & 23 & 24 \\
\hline 30 & 29 & 28 & 27 & 26 & 25 \\
\hline 31 & 32 & 33 & 34 & 35 & 36 \\
\hline
\end{tabular}

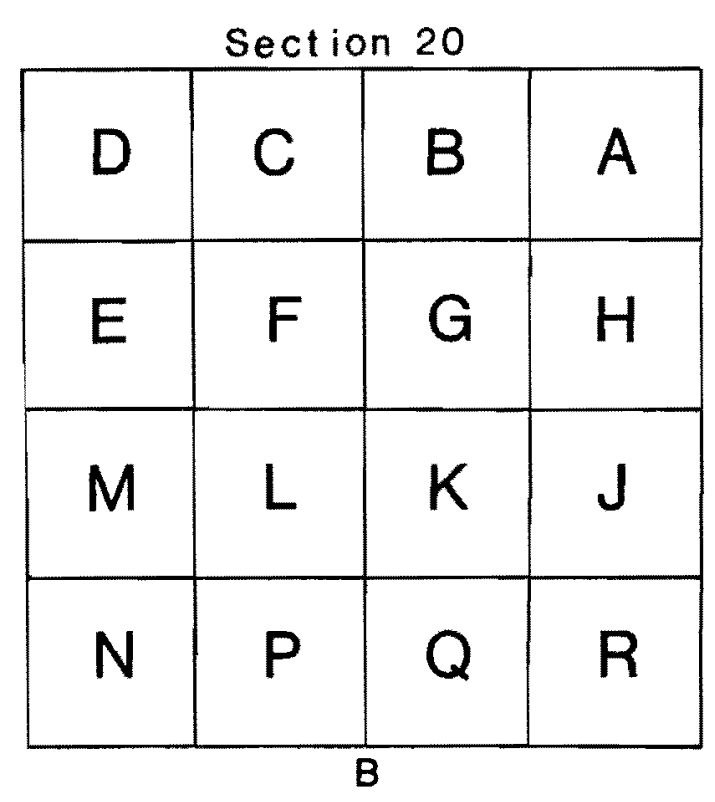

U.S. GEOLOGICAL SURVEY

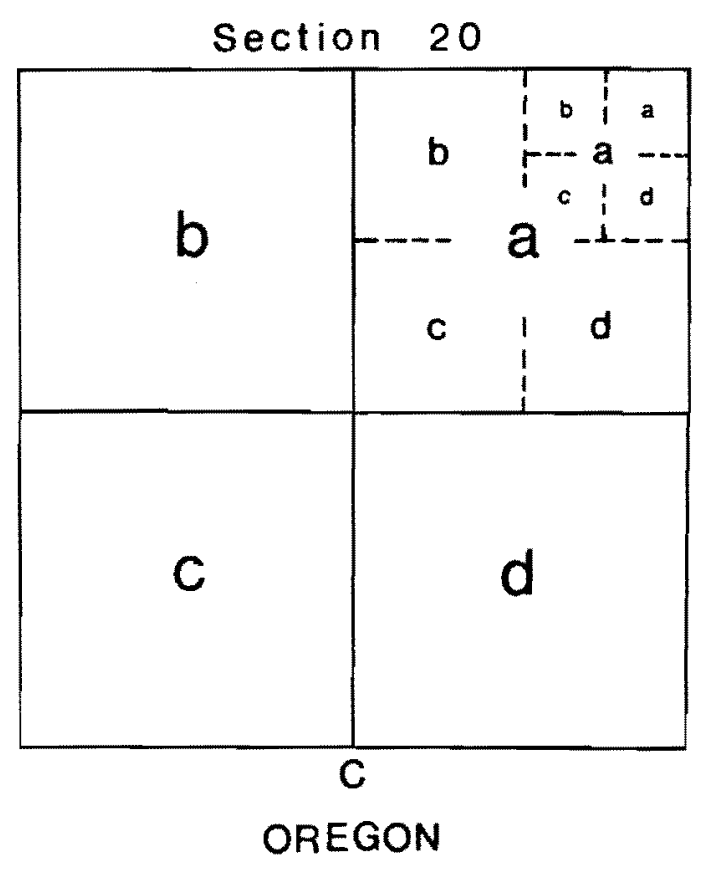

Figure 26. Explaination of well numbering system. 


\section{Drillers' Logs of Representative Wells}

\begin{tabular}{|c|c|c|}
\hline Materials & $\begin{array}{c}\text { Thickness } \\
\text { (feet) }\end{array}$ & $\begin{array}{l}\text { Depth } \\
\text { (feet) }\end{array}$ \\
\hline
\end{tabular}

1/1-36 A City of Milwaukie. 1960

Alluvium of abandoned river channel:

Topsoil . . . . . . . . . . . . . . 33

Gravel and sand . . . . . . . . . 2326

Gravel, loose, and sand (water). . . . 2046

Gravel, clay binder ... . . . . . 1561

Troutdale Formation:

Gravel, cemented . . . . . . . 3293

Gravel, loose . . . . . . . . . . 396

Grave1, cemented . . . . . . . . $34 \quad 130$

Gravel, clay binder . . . . . . . . $39 \quad 169$

Gravel, cemented . . . . . . . . . . 4173

Clay, sandy . . . . . . . . . . . . 8

Gravel, loose, and sand (water)...... 14195

Gravel, cemented . . . . . . . . . $79 \quad 274$

Gravel, loose, and sand (water) . . . . 9283

Gravel, cemented . . . . . . . . 6289

Clay, blue and brown ... . . . . . . 5 : 294

Gravel, pea . . . . . . . . . . 44298

Sandy River Mudstone:

Clay, blue . . . . . . . . . 6

1/2-31N1 Ambrose Calcagno. 1956

Alluvium of abandoned river channel:

Silt, sandy, yellow . . . . . . . . 2020

Sand, coarse, pure, packed . . . . . 15

Sand, trace of gravel . . . . . . . . 338

Sand, silty, micaceous (water) • . . - 5290

Gravel, fine, loose (water) •. •. . . 7797

Gravel, loosely cemented . . . . . . 6103

Gravel, some loosely cemented •. . . $28 \quad 131$

Gravel, loosely cemented (water) • • • • . $47 \quad 178$ 
Thickness

Depth

Materials

(feet)

(feet)

1/2-31P1 Omark Properties, Inc. 1964

Alluvium of abandoned river channel:

Fill . . . . . . . . . . . 11

Gravel and boulders . . . . . . 18

Gravel, slightly cemented ....... 18

47

Sand and gravel, some clay. . . . . . 25

72

Sand and gravel . . . . . . . . 35

107

Shale, blue...............48

155

Gravel with clay ........... 5

160

Sand and gravel ........... 12

172

Gravel and clay . . . . . . . . . . . 2

174

Shale, blue ............ . 27

201

Clay, sandy ............. 8

209

Sand and gravel............ 6

215

Troutdale Formation:

Gravel, cemented . . . . . . . 25

Sand and gravel . . . . . . . . . 11

Gravel, cemented . . . . . . . . 9

Sand and gravel............ . 16

Decompos ed formation. . . . . . . 13

Sandy River Mudstone:

Clay, brown ............11

2/1-1A Camillo Giacchero. 1964

Alluvium of abandoned river channel:

Sand, fine, brown . . . . . . . . 39

Clay, sandy, green . . . . . . . . . 8

Sand, fine, gray. . . . . . . . . 46

Sandy River Mudstone:

Clay, gray . . . . . . . . . . 25

Clay, brown ................ 3

Clay, green . . . . . . . . . . . . 9

Sand, fine, gray. ............. 10 


\begin{tabular}{|c|c|c|c|c|c|c|c|c|}
\hline Materials & & & & & & & $\begin{array}{c}\text { Thickness } \\
\text { (feet) }\end{array}$ & $\begin{array}{l}\text { Depth } \\
\text { (feet) }\end{array}$ \\
\hline Milwaukie Elks. & 1966 & & & & & & & \\
\hline \multicolumn{9}{|l|}{ Columbia River Basalt: } \\
\hline Topsoil . • . . . & . & - & & & - & • & - 2 & 2 \\
\hline Clay, red . . . . &. & - & & & - & - & . 10 & 12 \\
\hline Rock, broken, soft . & - . & - & - & - & - & & . 56 & 68 \\
\hline Basalt, gray . . . & - . & . & - & - & - & • & - 35 & 103 \\
\hline Basalt, black ... & - . & - & - & - & . & - & - 20 & 123 \\
\hline Basalt, broken . . & .. & - & & & • & & - 25 & 148 \\
\hline Basalt, medium hard, & black & - & & & - & & - 6 & 154 \\
\hline Basalt, broken . . & . . . & - & 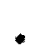 & - & - & - & 4 & 158 \\
\hline Basalt, medium hard, & black & - & - & & . & • & - 3 & 161 \\
\hline Basalt, porous, black & . . . & - & $*$ & - & - & • & - 14 & 175 \\
\hline Basalt, hard, black. & - & - & : & . & - & & - 16 & 191 \\
\hline Basalt, hard, gray. & . & - & . & . & - & & . 10 & 201 \\
\hline
\end{tabular}

2/2-9 Bl A. L. Alexander. 1927

Alluvium of a bandoned river channel:

Soil and clay . . . . . . . . 5

Troutdale Formation:

Gravel, cemented .......... 1116

Sand ................. 2

Gravel, cemented . . . . . . . $10 \quad 28$

Gravel, cemented, and sand . . . . . 5 33

Gravel, cemented ......... 5 . . 38

Sand ............... $10 \quad 48$

Gravel, cemented, sandy ....... 7

Sand .............. 666

Sand, cemented .......... 4465

Sand, fine ............ 13

Gravel, cemented ......... 2 80

2/2-9 J Loren Mathews.

Alluvium of abandoned river channel and Troutdale Formation:

Topsoil .............. 11

Gravel, heavy ........... 39

Sand and gravel, big ......... 747

Gravel ............ 6 


\begin{tabular}{ccc}
\hline & Thickness & Depth \\
Materials & (feet) & (feet) \\
\hline
\end{tabular}

\section{2/2-10F Oak Acres Mobile Homes. 1967}

Alluvium of abandoned river channel and Troutdale Formation:

Topsoil . . . . . . . . . . 6

Cemented gravel ......... 39

Sand ................ 2

Clay, blue............ 20

Gravel, hard............. 1

Clay, blue.............. 8

Gravel ............. 1

Clay, blue, sticky ........... 3

Sand, gray, and gravel ....... . 35

Shale, green ............. 12

Sand, gray, and gravel ........ 13

127

Sand, gray, medium grain. . . . . . 6

Sand, fine ............. 2

Sand, gravel, cobble rock. ....... 41

Clay, sticky . . . . . . . . . . . 1

Sand, loose, and gravel ........ 9

Clay, hard, sandy .......... 2

Sand, loose, and gravel........ 24

Shale, blue, sticky.......... 5

Shale and gravel streaks ........ 15

Sand and shale streaks . . . . . . $51 \quad 296$

Shale .............. $16 \quad 312$

2/2-15D Byrum W. Morehouse.

Alluvium of abandoned river channel and Troutdale Formation:

Sand and gravel, cemented ...... 113

Soapstone . . . . . . . . . 75

Sand, fine (water) .......... 14

Gravel (water)............ 2204

Sandy River Mudstone:

Clay, blue and clay, sand ....... 96

Shale, green . . . . . . . . 20

Clay, gray with seams of sand, fine (water). 27 


\begin{tabular}{lcc}
\hline & $\begin{array}{c}\text { Thickness } \\
\text { (feet) }\end{array}$ & $\begin{array}{c}\text { Depth } \\
\text { (feet) }\end{array}$ \\
\hline
\end{tabular}

2/2-16B1 F. J. Mooney. 1958

Alluvium of abandoned river channel:

Clay, gravelly,brown . . . . . . . 44

Gravel, lightly cemented ......... 1115

Gravel, loose (water) . . . . . . . 1116

Gravel, lightly cemented . . . . . . 319

Troutdale Formation:

Gravel, cemented, with layers of brown clay $12 \quad 31$

Gravel, cemented (water)....... 839

Shale, gray . . . . . . . . . . 645

Gravel, cemented .......... 651

2/2-16K Donald Hugart. 1970

Recent alluvium and Troutdale Formation:

Clay, brown . . . . . . . . . . $15 \quad 15$

Gravel, large . . . . . . . . . 17

Gravel, medium .. . . . . . . . 844

Gravel ... . . . . . . . . . 114

Sandy River Mudstone:

Clay, gray, sandy . . . . . . . . 2465

Clay, gray .............. 45 45110

Clay, blue, sandy .......... . 6

Clay, gray . . . . . . . . . . . 29

Clay, gray, sandy ........... . 5

Sand, coarse . . . . ......... 9

Clay, gray ............... 11

2/2-16K3 Oak Lodge Water District. 1957

Recent alluvium and Troutdale Formation:

Loam, sandy, and soil . . . . . . . . 14

Gravel, cement, $6^{\prime \prime}$ and smaller, bound

with brown clay . . . . . . . . 721

Boulders, large with clay binder. . . . . 526

Sand and gravel, water bearing . . . . 1.527 .5

Sandy River Mudstone:

Clay, blue (light blue) . . . . . . 22.5 50 
Thickness

De pth

Materials

(feet)

(feet)

2/2-20F1 City of Gladstone. 1949

Lacustrine deposits:

Clay and boulders. . . . . . . . . 11

Clay, blue and yellow. . . . . . . . 29

11

Clay and sand . . . . . . . . . . 15

40

Shale, brown, sandy .... . . . . . 20

Columbia River Basalt:

"Shale rock" (weathered basalt?). . . . . 12

Rock, gray, solid ... . . . . . . . 1

Rock, blue, hard..... . . . . . . 7

Rock, hard, fractured . . . . . . . 15

Rock, solid . . . . . . . . . . . 7

Clay and shale (weathered zone in the basalt?) 13

Rock, soft... . . . . . . . . . 5

Basalt, black ......... . . . 40

Basalt (water) . . . . . . . . 500

Basalt (water, saline) .......... 10

Scappoose Formation:

Shale, blue (water, saline) . . . . . 7

692

2/3-18J L. D. Carlson. 1965

Terrace deposits:

Silt, brown . . . . . . . . . . 8

Gravel and boulders, cemented . . . . 16

Silt, blue . . . . . . . . . . . . 13

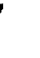

ndy River Mudstone:

Clay, blue, silty . . . . . . . . 37

Gravel . . . . . . . . . . . . . 1

Clay, blue.............. . 39

Silt, blue . . . . . . . . . . . 8

Sand, gray . . . . . . . . . . . 19

Clay, blue, sticky ........ . . 37

Clay, gray . . . . . . . . . . 7

Sand, gray . . . . . . . . . . . 7

Clay, gray, silty ..... . . . . . 32

Clay, blue, sticky.......... 63

Clay, gray ............ . . 30

Silt, brown .. . . . . . . . . . . 7

Clay, blue............... . 33 


\begin{tabular}{ccc}
\hline Materials & $\begin{array}{c}\text { Thickness } \\
\text { (feet) }\end{array}$ & $\begin{array}{c}\text { Depth } \\
\text { (feet) }\end{array}$ \\
\hline
\end{tabular}

Sandy River Mudstone continued:

Sand,gray ............ 13

Clay, gray ............ 99379

Clay, blue............ 11

Clay, gray ........... 60

Shale, blue, crumbly......... 6

2/3-18N Leon Dow.

Terrace deposits:

Gravel, cement, and boulders . . . . 2727

Sandy River Mudstone:

Clay, blue, sticky ......... 5 . 52

Clay, gray, sandy .......... 19

Clay, blue, sandy .......... 15

Conglomerate, green . . . . . . 4

Clay, gray ............ 40 40110

Clay, green, sandy. . . . . . . 12

Clay, blue, sandy ........... 14

Clay, gray, sandy ........... 12

Sand, gray, coarse........... 11149

Sand and gravel $\left(1 / 2^{\prime \prime}\right)$........ 1150

2/3-19M Tommy Gene Vanderflute.

Estacada Formation:

Topsoil, brown ............ 11

Gravel, medium ........... $20 \quad 21$

Clay and sand, fine, gray....... 13

Sand, medium ............ 84

Sandy River Mudstone:
Clay, blue............. 19 


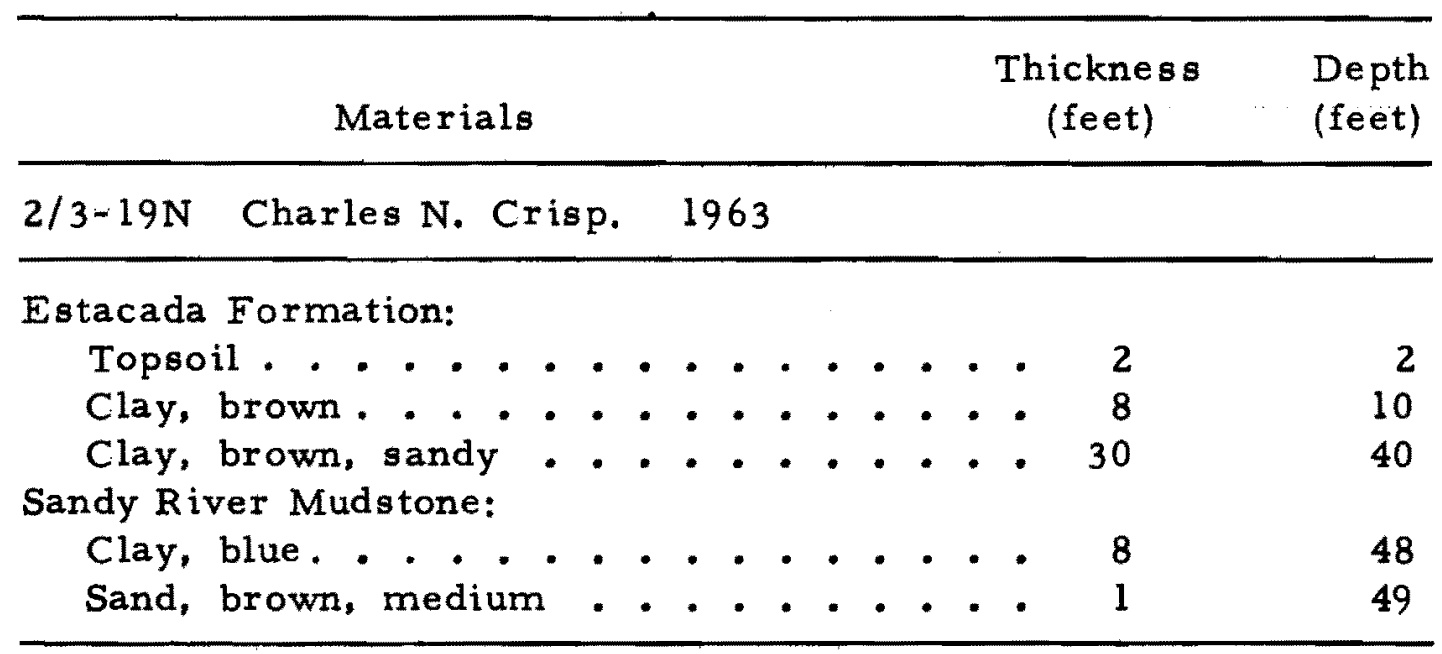

2/3-27L Elbert Simpkins.

Estacada Formation:

Topsoil . . . . . . . . . . . . 1

Clay, brown, sticky ........... 14

Troutdale Formation:

Boulder and gravel conglomerate. - . . - 3449

Sandy River Mudstone:

Clay, gray, sticky . . . . . . . $75 \quad 124$

Sand, gray, conglomerate . . . . . . 44128

Clay, gray, sticky ............ 19

Silt, gray, conglomerate . . . . . . 13160

Clay, gray, sticky . . . . . . . . . $25 \quad 185$

Sand, gray, fine ............ . . 3188

Clay, gray, sticky ........... 15203

Silt, gray, conglomerate......... $11 \quad 214$

Clay, gray, sticky . . . . . . . . 82296

Sand, shale, gray .. . . . . . . 52301

2/3-30D Alfred Aus.

Gresham Formation:

Clay, silty, yellow and brown ...... $15 \quad 15$

Clay, silty, gray .. . . . . . . 3045

Gravel, loose, and sand, coarse. . . $10 \quad 55$

Sandy River Mudstone:

Clay, gray . . . . . . . . . . 964 
Materials

Thickness

Depth

(feet)

(feet)

\section{2/3-30D Ernest T. MacFarlane.}

Gresham Formation:

Sand, black, and gravel .... . . . . 444

Mud, blue, and gravel . . . . . . . . 1014

Sandy River Mudstone:

Clay . . . . . . . . . . . 90

104

2/3-31D John F. Delval. 1949

Gresham Formation:

Gravel and boulders, cement. . . . . 3636

Troutdale Formation:

Clay . . . . . . . . . . . . 2460

Clay and clay, sandy ........... $40 \quad 100$

Clay and clay, sandy, some sand. . . . . 85185

Sand and gravel, cemented . . . . . 45230

Sand and gravel, loose, coarse . . . . . 12242

2/3-31cac Adolph Deininger.

Gresham Formation:

Topsoil . . . . . . . . . . . . 11

Clay, brown ................ 11

Troutdale Formation:

Gravel, conglomerate. . . . . . . 2739

Clay, brown .. . . . . . . . . . 544

Clay, gray ............... $10 \quad 54$

Gravel, conglomerate, loose . . . . 1367

Gravel and sand . . . . . . . . 2087

2/3-31L Howard DeLano. 1959

Gresham Formation:

Clay ................ 3535

Troutdale Formation:

Gravel, boulders, clay . . . . . . 2964

Gravel, dry . . . . . . . . . . 2266

Boulders, gravel and clay. . . . . . . 975

Sand . . . . . . . . . . . . 277

Gravel, cemented ........... 1087 


Materials
$\begin{gathered}\text { Thickness } \\ \text { (feet) }\end{gathered}$ $\begin{gathered}\text { Depth } \\ \text { (feet) }\end{gathered}$

2/3-31M Vernie Renaud. 1962

Gresham Formation (?):

Clay, yellow . . . . . . . . . . . 444

Clay, yellow, and boulders ....... 610

Clay, yellow, and gravel . . . . . . 3040

Clay, yellow, sticky . . . . . . . . 949

Troutdale Formation:

Gravel, yellow, cement . . . . . . 7756

Sand and gravel, loosely cemented . . . . 2884

Clay, yellow . . . . . . . . . 2

Gravel, loose (water)...... . . 793

2/3-33abc Elmore Mostul.

Gresham Formation:

Clay, brown . . . . . . . . . 3 . 3

Troutdale Formation:

Gravel, cement, and boulders . . . . 7275

Gravel, loosely cemented . . . . . . $20 \quad 95$

Gravel, loose ............. 10105

Gravel, cemented, gray ........ $16 \quad 121$ 


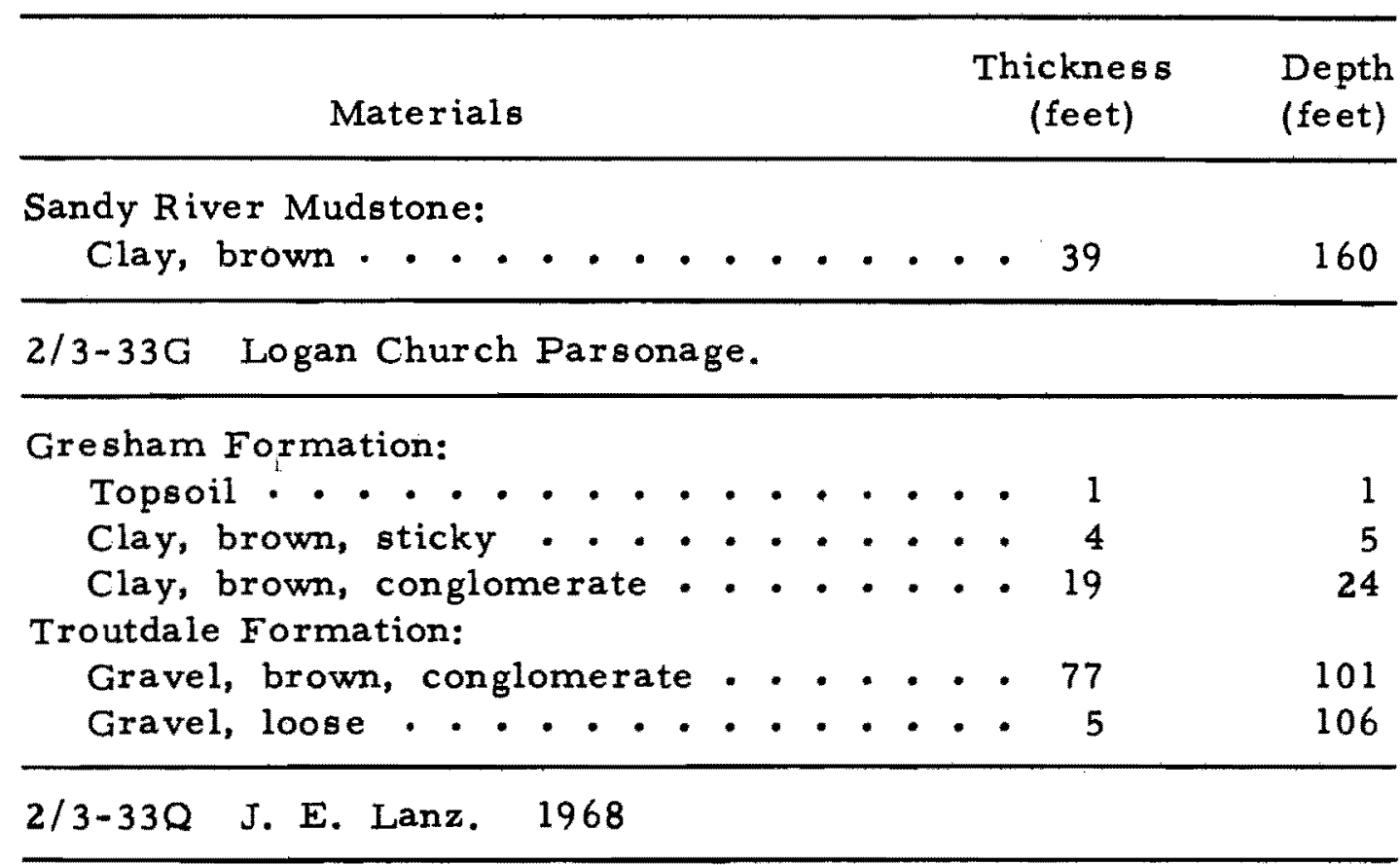

Gresham Formation:

Clay, orange, sticky . . . . . . . . 11

Clay, granular, $\tan$........... $6 \quad 17$

Troutdale Formation:

Grave1, cement . . . . . . . 3047

Clay, brown .............. 350

Gravel, loose............. 1363

Rock, gray, soft............. 1073

3/3-5G1 Washore Turkey Association.

Gresham Formation:

Clay, large boulders . . . . . . 3535

Boring Lava:

Lava, hard . . . . . . . . . 59

Troutdale Formation:

Shale................. . 35140

Sand, cemented . . . . . . . . 10150

Shale . . . . . . . . . . . 36206

Rock, hard, sedimentary ........ 9215

Shale . . . . . . . . . . $35 \quad 250$ 


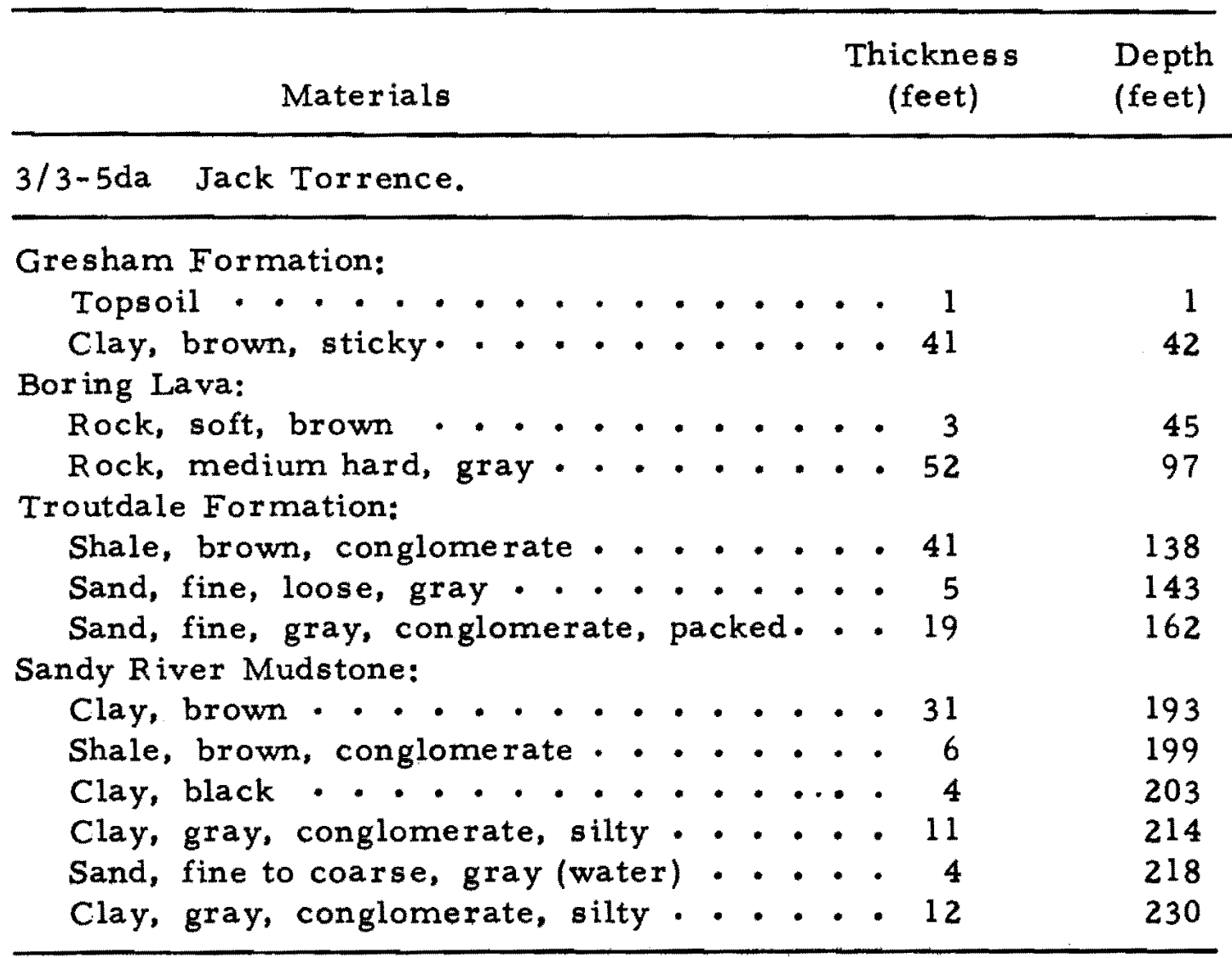

3/3-6J Ray Sievers.

Boring Lava - weathered:

Clay, brown . . . . . . . . . . 1414

Clay, brown and blue... ....... . 620

Clay, brown, gritty .. . . . . . . 4565

Troutdale Formation:

Sand, medium,yellow . . . . . . . 2085

Clay, brown .............. 1095

Clay, blue ............ 8 . . 803

Clay, green ............... 12115

Clay, gray ............... 8

Clay, brown ............... 26149

Sand, fine, yellow . . . . . . . 10159

Gravel, small, and sand, coarse, cemented. $36 \quad 195$

Sandy River Mudstone:

Clay, brown, gritty . . . . . . . . 14209

Clay, blue, gritty ............ 21230

Clay, gray, gritty •. •. . . . . . 11

Clay, blue, gritty . . . . . . . 69

Clay, gray ............. $61 \quad 371$ 


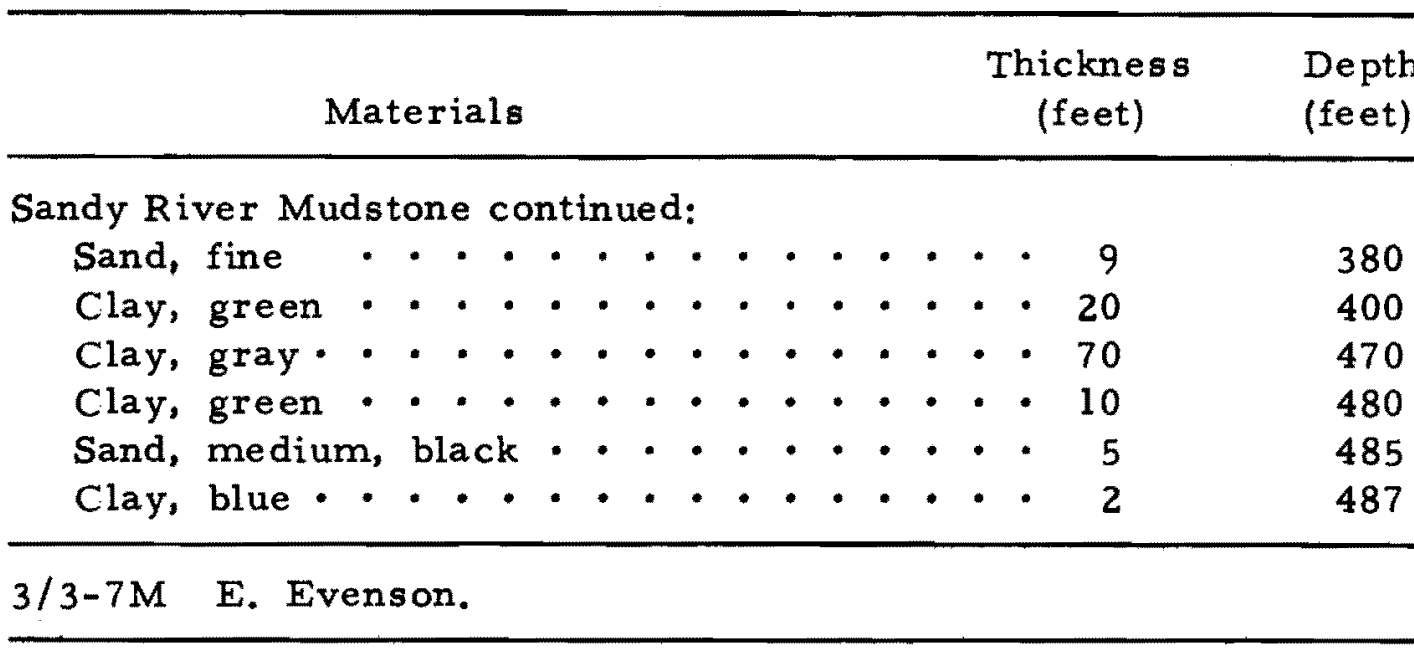

Sandy River Mudstone:

Topsoil and clay, red . . . . . . - 2424

Clay, blue .. . . . . . . . . . 28

Sand, blue . . . . . . . . . . . 2

Clay, blue . . . . . . . . . 2983

Sand and silt, gray, dark •. - . . . 1598

Sandstone, blue. . . . . . . . . . 9 107

Clay, blue . . . . . . . . . . . 10117

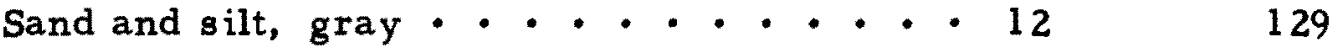

Clay, blue .............. 232152

Silt, gray •. • . . . . . . . . . $20 \quad 172$

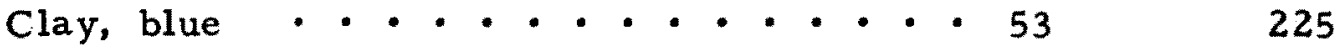

Clay, blue, sticky*... . . . . . . $15 \quad 240$

Silt, gray, and clay. . . . . . . . 12

Silt, gray (wet) . . . . . . . . . 10262

Clay, blue . . . . . . . . . . 18

Shale, blue. . . . . . . . . . $50 \quad 330$

Columbia River Basalt (?)

Weathered basalt .. . . . . . . 142

Shale, dark, hard . . . . . . . 45

Sand and gravel •. • . . . • . . . 3520

3/3-11G Melvin Welker.

Springwater Formation:

Dirt and gravel and boulders • • - . - $17 \quad 17$

Gravel and boulders, cement. . . . . 3047

Clay, brown . . . . . . . . . . 4 41

Troutdale Formation:

Gravel, cement . . . . . . . . 1263

Clay, brown . . . . . . . . 1275 
Materials

Thickness

Depth

(feet)

(feet)

3/3-13A or $\mathrm{H}$ Glen H. Hill. 1961

Estacada Formation:

Soil . . . . . . . . . . . . . 3

Boulders .............. 1316

Sandy River Mudstone:

Clay . . . . . . . . . . . 5

Clay, blue.............. 200

Rhododendron Formation:

Rock and boulders .......... . 4

Clay, blue... ......... . . 58

Rock .. . . . . . . . . . 32

Rock, soft .............. 62

3/3-14A Herman Durschmidt.

Springwater Formation:

Clay, brown ............. 2323

Clay, brown, and boulders ....... 225

Clay, brown .............. . 429

Troutdale Formation:

Gravel, cement . . . . . . . 2655

Gravel, loose, cement ........ 56

Clay, brown ............. 1272

Clay, gray............... . 981

3/3-14aca Donald R. Smith. 1967

Springwater Formation:

Loam, brown ............. 33

Clay, brown, and gravel, large . . . . 1922

Gravel, large ............. 224

Troutdale Formation:

Gravel, cemented . . . . . . . 5983

Clay, gray .............. $50 \quad 133$

Clay, gray, and wood . . . . . . 19152

Sandy River Mudstone:

Clay, light blue ............ $21 \quad 173$

Clay, yellow, and gravel, white . . . 9182

Clay, gray. . . . . . . . . 38220 
Thickness

Depth

Materials

(feet)

(feet)

\section{3/3-15bb Robert Kiefer. 1970}

Boring Lava:

Topsoil . . . . . . . . . . . . 4

Clay, red . . . . . . . . . . . 18

Clay, brown ............... 8

22

Clay, shale, gray . . . . . . . . 10

30

Lava, broken (2 gpm) . . . . . . . . . 4

Lava, gray. . . . . . . . . . . . 226

Troutdale Formation:

Clay, gray. . . . . . . . . . . 47

Gravel (4 gpm) . . . . . . . . . . 4

Clay, gray. . . . . . . . . . 73

Gravel, pumice (18 gpm) ........ . 22

394

Clay, gray....... . . . . . . . 14

416

Sand, coarse, and gravel, small .. . . . 23

Sandy River Mudstone:

453

Clay, gray . . . . . . . . . . 19

472

Sand, gray, medium .......... . 10

482

Clay, gray. . . . . . . . . . . 92

572

Clay, black, hard ............ 14

586

Clay .. . . . . . . . . . . . . 9

595

Sand, gray $(30 \mathrm{gpm}) \cdot . \cdot \cdot .^{\cdot} \cdot . \cdot \cdot 10$

Clay, gray ............. . 70

675

Sand, gray (42 gpm) ......... . . 7

Clay ... . . . . . . . . . . 5

Shale, gray ............... 29

Clay, gray..... . . ....... . . 26

742

Columbia River Basalt (?):

Basalt, black . . . . . . . ... . 18

Basalt, black, soft . . . . . . . . 4

Clay, gray, hard and soft ....... . 71

835

3/4-7D Ralph (Simmy) Heiple.

Estacada Formation:

Terrace deposits . . . . . . . . . 54

Sandy River Mudstone:

Clays and some sands . . . . . . . 46 


\section{Thickness}

Depth

Materials

(feet)

(feet)

3/4-7Q E. L. Williams.

Estacada Formation:

Terrace deposits . . . . . . . . 42

42

Sandy River Mudstone:

Clays and some sands ....... 13

3/4-8Ml Stuart Puckett.

Estacada Formation:

Terrace gravels .......... 60

3/4-9F Ardel Zach.

Springwater Formation:

Terrace gravels . . . . . . . 25

Sandy River Mudstone (all?):

Clay, gray ........ . . . 8

Clay, blue ............. 42

Clay, brown, and shale........ 18

Clay, blue .............. 67

Clay, gray ............. 98

Clay, blue ........... 37

Clay, gray ............. 7

Clay, blue .............. 2 304

Rhododendron Formation:

Basalt, gray, soft . . . . . . 38

Basalt, clay, gray ........... 2

Basalt, gray, medium hard . . . . . $26 \quad 370$

Basalt, gray, soft ......... 20

3/4-18ba Floyd R. Ashworth.

Estacada Formation:

Clay, brown .............. 11

Gravel, cement . . . . . . . 4647

Sandy River Mudstone:

Clay, brown ............ 4451

Clay, gray ............. 1263

Clay, blue.............. $42 \quad 105$ 


\begin{tabular}{ccc}
\hline Materials & $\begin{array}{c}\text { Thickness } \\
\text { (feet) }\end{array}$ & $\begin{array}{c}\text { Depth } \\
\text { (feet) }\end{array}$ \\
\hline
\end{tabular}

Sandy River Mudstone continued:

Sand, gray, fine . . . . . . . . 3108

Clay, blue ............... 130238

Sand, gray, coarse . . . . . . . . 5243

3/4-21M S. S. Dunlop (Well No. 1). 1963

Rhododendron Formation:

Clay, yellow, and boulders . . . . 18

Clay, yellow, granular . . . . . . 14

Clay, blue, sticky .......... 28

Clay, gray, granular.......... 15

Rock, gray, soft........... 119

Shale, bluish green........... 19

Rock, gray, soft ........... 205

Rock, pinkish gray .......... 22

Rock, bluish gray, soft ......... 20

Shale, blue, with ribbons of brown . . . 10

Rock, bluish gray ......... 45

Shale, brittle, bluish gray ....... 10

Rock, gray, soft .......... 35

Rock, red, soft .......... 3

Rock, blue, shaley, with white specks . . 99

Clay, blue............. 3

Clay or shale, green, gritty . . . . $15 \quad 680$

Rock, bluish green......... 25

Rock, black ............. 43

Rock, gray, dark (soft) . . . . . . 31

Rock, gray, hard ......... 25

Columbia River Basalt (?):

Shale, brittle, blue, with streaks . . . 23

of hard gray rock (basalt?) . . . . . 21

Rock, black, hard ......... 11

Rock, gray, hard .......... 34

Rock, bluish gray, softer ........ 14

Rock, bluish gray, hard. ....... 18

Rock, gray, medium hard......... 19

Note: "Most all of the rock from 75 feet to 827 feet has lots of crystal or glass in it. From 827 feet on I believe it is mostly Columbia River basalt. Hole made no water below 150 feet" 
3/4-27K Basil Weathers. 1968

Springwater Formation:

Clay and gravel . . . . . . . . 17

Clay, brown, sticky . . . . . . . . 5

Clay, gray, sticky ... . . . . . . 10

Clay, tan, sandy ............. . 13

Gravel and sand ... . . . . . . . 11

Clay, brown . . . . . . . . . . . 2

Gravel, cemented . . . . . . . . 9

Clay, brown ....... . . . . . . 8

Sand, gray . . . . . . . . . . . . 2

Gravel . . . . . . . . . . . 10

Clay, gray . . . . . . . . . . 3

Clay, pink . . . . . . . . . . 28

3/4-28 B Robert E. McConnell.

Springwater Formation:

Clay, yellow, with boulders . . . . . 2626

Clay, yellow, sticky . . . . . . 834

Clay, orange . . . . . . . . . 31 65

Clay, brownish yellow. . . . . . . 3398

Rhododendron Formation:

Rock, bluish gray, soft .......... $16 \quad 114$

Conglomerate, yellow . . . . . . . 16, 130

Rock, bluish gray, soft .......... 21

Rock, bluish gray, broken (water) . . . 6156

3/4-28 B H. L. Duvall.

Springwater Formation:

Clay, brown . . . . . . . . . . 2929

Boulders and clay ... . . . . . . 1039

Sand .................. 444

Gravel, cement . . . . . . . . 447

Gravel, loosely cemented . . . . . $10 \quad 57$ 
3/4-28aba Robert L. Poore. 1964

Springwater Formation:

Clay, yellow, and boulders . . . . . . 1515

Clay, white . . . . . . . . . 722

Clay, blue . . . . . . . . . . . 426

Clay, gray, granular . . . . . . . 2450

Clay, brown ............. 656

Clay, red............... 1672

Clay, light gray . . . . . . . . . 13

Clay, tan ............... 1499

Rhododendron Formation:

Rock, bluish gray . . . . . . . . . 43

3/4-28baa Jack Broadhurst.

Springwater Formation:

Gravel, decomposed, and clay, yellow • . 2525

Clay, white.............. 1035

Rhododendron Formation:

Rock, blue, with white specks . . . . $10 \quad 45$

Rock, bluish, with lots of quartz in it . . . 2570

Rock, bluish gray, with boulders. . . . 15

Rock, bluish gray, with white and red

specks in it . . . . . . . . . . . . 40 425

3/4-29adc Kenneth Meeker.

Estacada Formation:

Clay, brown, sticky . . . . . . . . 1313

Clay, gray . . . . . . . . . . . 316

Gravel and boulders, cemented . . . . 1632

Clay, brown, sandy .. . . . . . . 2234

Gravel, cemented ........... 11

Rhododendron Formation:

Rock, gray, soft . . . . . . . . 64109

Rock, medium hard ......... $21 \quad 130$ 
Thickness

Depth

Materials

(feet)

(feet)

3/4-29adb Norman Hall.

Terrace deposits:

Gravel, cemented, and boulders, large . . . 32

Clay, gray

Rhododendron Formation:

Rock ............... 120

3/4-29bcc Eugene C. Shore. 1970

Gresham Formation:

Topsoil, clay, brown, sandy . . . . . 4

Clay, brown, layers of coarse gravel. . . 18

Gravel, medium to coarse, with sand streaks 48

Rhododendron Formation:

Rock, soft, broken ... . . . . . . 37

Rock, hard, fractured (water) . . . . . 5 


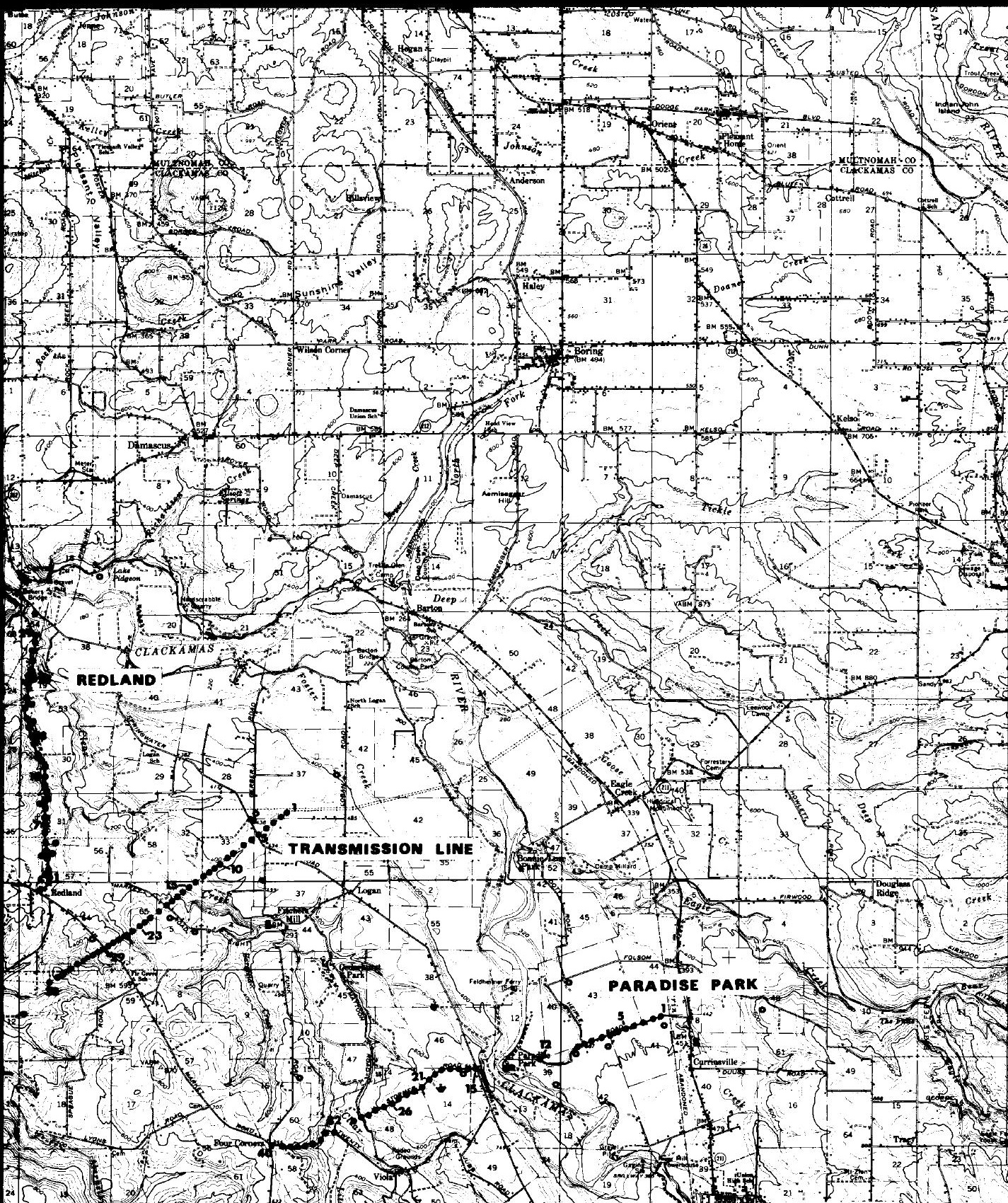

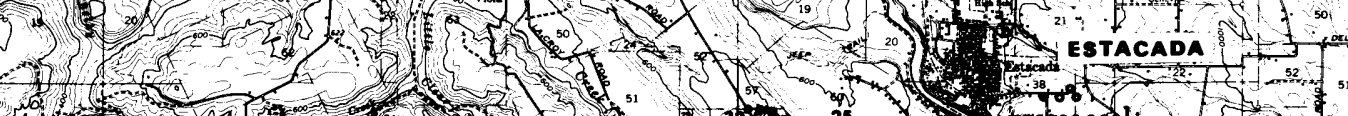




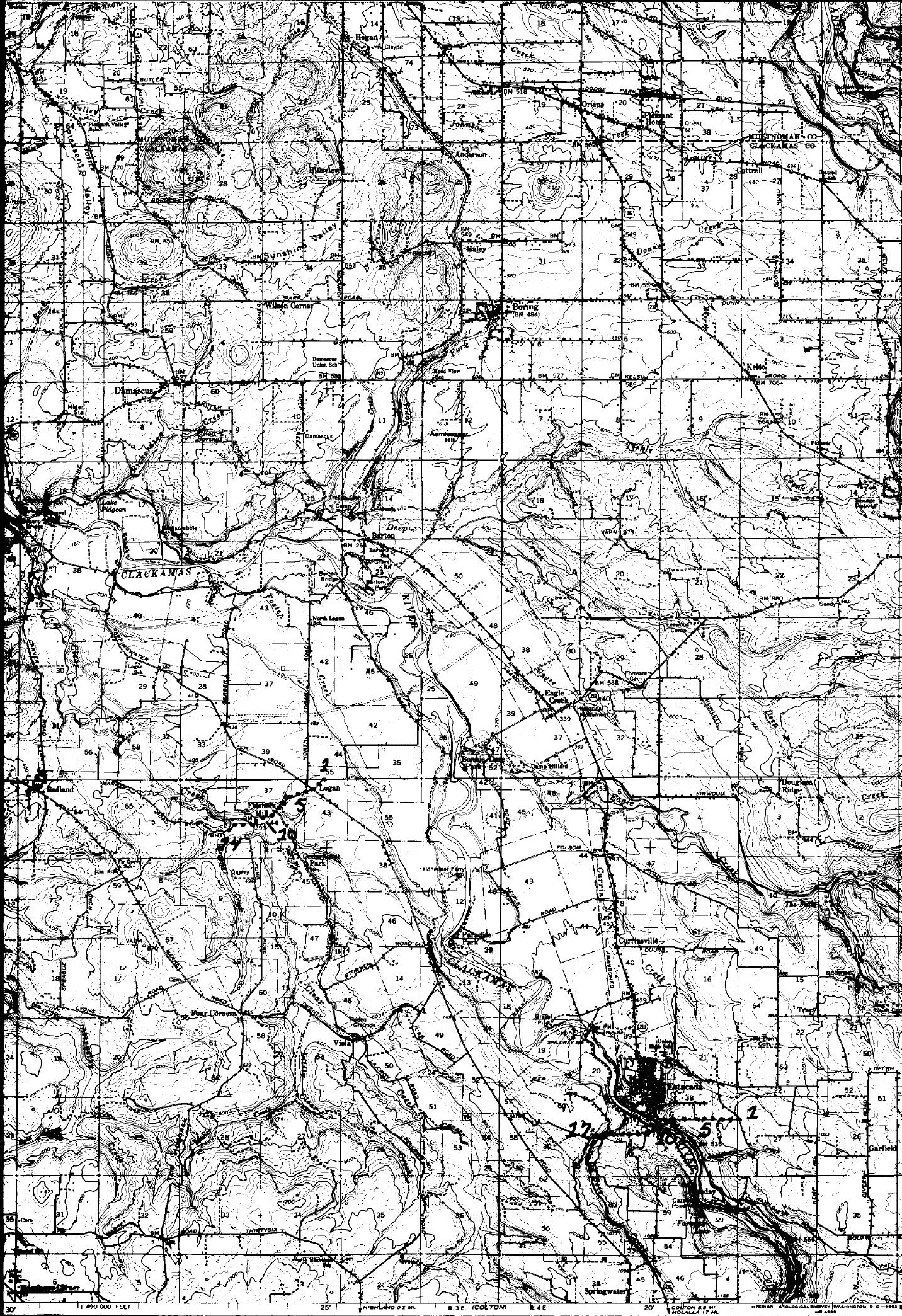


$=$

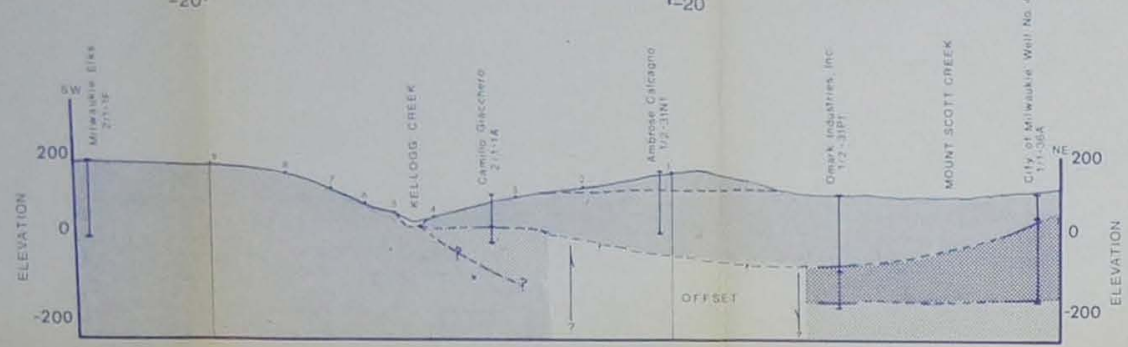

Figure 19 Milwaukie Traverse

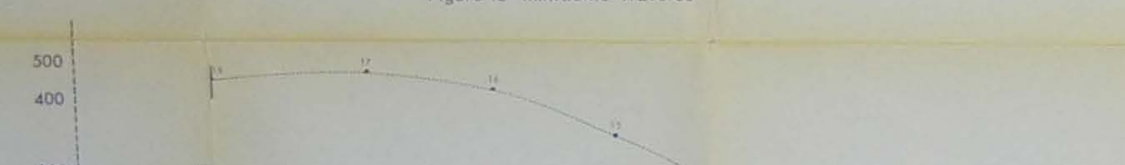

\begin{tabular}{|r|r|}
200 & -15 \\
-200 & -25
\end{tabular}
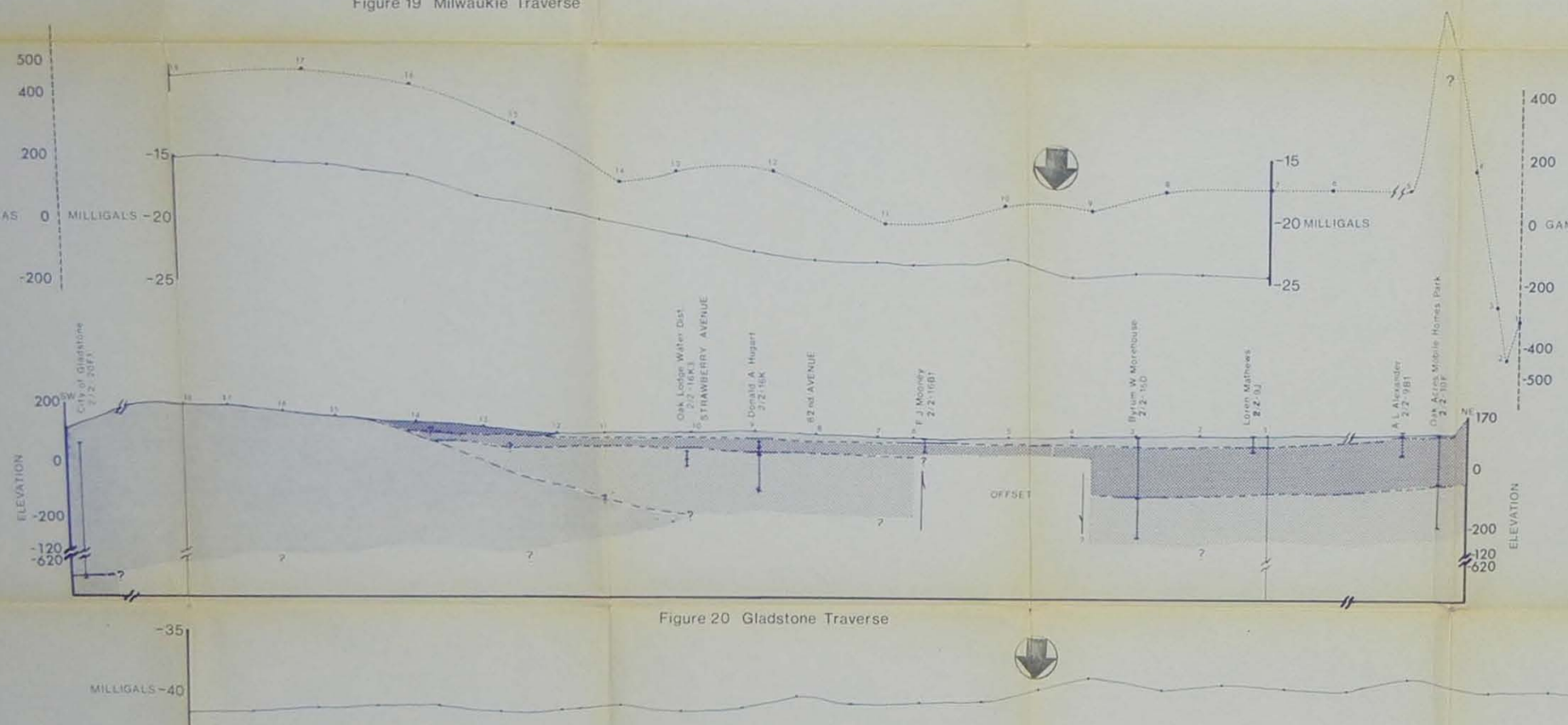

Figure 21 Redland Traverse

$\rightarrow$

\section{BOUGUER \\ AND}

ANOMALIES

GEOLOGIC CROSS SECTIONS

RONALD J SCHMELA
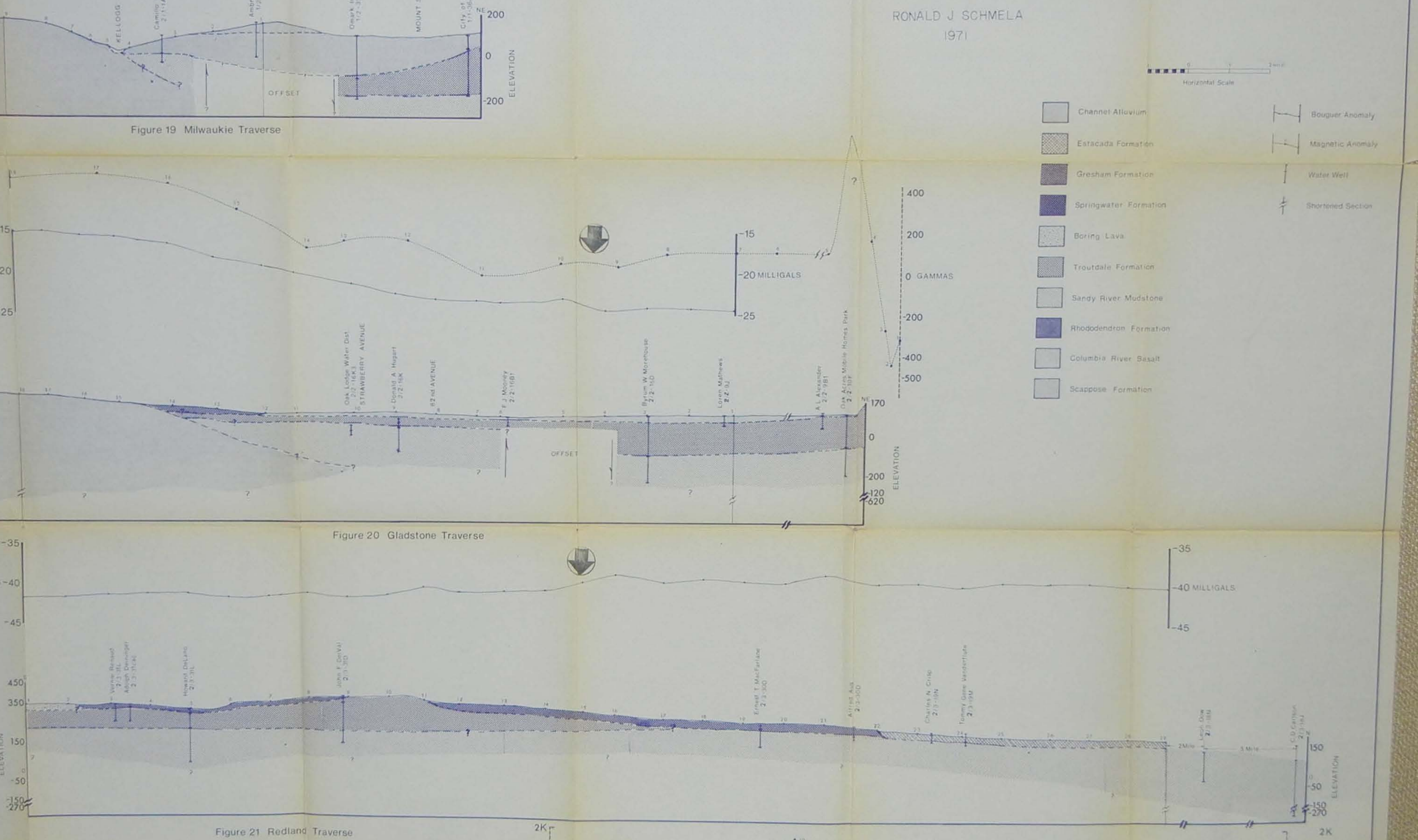

Figuro 24 Eotacada Traverse

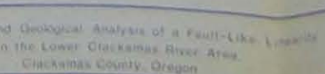

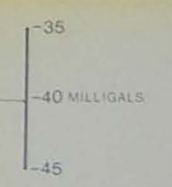


